\title{
Silver Hake of Scotian Shelf: Fishery, Environmental Conditions, Distribution, and Biology and Abundance Dynamics
}

\author{
V. A. Rikhter, I. K. Sigaev, V. A. Vinogradov, and V. I. Isakov \\ Atlantic Scientific Research Institute of Marine Fisheries and Oceanography (AtlantNIRO) \\ 5 Dm. Donskoy Street, Kaliningrad, 236000 Russia
}

\begin{abstract}
The results of USSR/Russian scientific research on silver hake (Merluccius bilinearis) population on the Scotian Shelf (NAFO Div. 4VWX) with regard to environmental conditions, distribution, biology and abundance dynamics are summarized for the period from the early-1960s to 1997. A brief description of the fishery is provided. Silver hake of the area form a self-reproducing group, geographically separated from more southwesterly stocks. They distribute demersally for the most part of the year and form aggregations mainly in deep-water depressions of the shelf and warm slope waters. Silver hake may be classified as a species with a high rate of renewal and of pronounced abundance fluctuations in response to climatic variations. The effect of any stock-recruitment relationship is over-shadowed by the impact of oceanographic factors within a wide range of spawning biomass. This paper makes an attempt to predict the trends of abundance of the silver hake population in the late-1990s and the first decade of the next century. While sharp variations of year-class abundance are caused by environmental variability, it is suggested that during this period, favourable conditions are expected for formation of relatively strong year-classes and, therefore, for good fishing.
\end{abstract}

Keywords: Abundance, biology, distribution, environment, Scotian Shelf, silver hake

\section{Introduction}

Silver hake (Merluccius bilinearis), distributed in the Scotian Shelf area (NAFO Div. 4VWX) off eastern Canada has been researched extensively due to its commercial importance to the international fishery. Most fishing effort during the years of this study was by USSR and Russian fishermen. Silver hake plays an important role in the shelf ecosystem due to its high abundance. Taking into account the above, it is obvious why scientists of USSR/Russia (major fishing nation) and Canada (Coastal State) have made the largest contribution to the research of this species.

In this article the main results of silver hake research carried out by USSR/Russian scientists in early-1960s to the late-1990s on the Scotian Shelf are summarized from many reports prepared, which highlighted various aspects of biology, distribution and dynamics of abundance in the area. The biological samples of silver hake collected from the area during the period considered, by observers on board the USSR/Russian fishing vessels (59 cruises) as well as oceanographic data and samples obtained from 50 research cruises conducted by Atlantic Scientific
Research Institute of Marine Fisheries and Oceanography (AtlantNIRO) were used. About 257000 individual silver hake in total were analyzed. The information is scattered among various articles and scientific documents of International Commission for the Northwest Atlantic Fisheries (ICNAF) and Northwest Atlantic Fisheries Organization (NAFO). However, until now no collective work has been pub-lished summarizing the numerous scientific data. Although emphasis is placed on synthesizing USSR/Russian contributions, references to the work of Canadian scientists whose contributions to the knowledge of silver hake life cycle can be hardly over-estimated. In addition, some important areas of research during this long-term study period were carried out under joint USSR/Russian and Canadian programs or in close cooperation with Canadian scientists.

The authors did not make it their aim to consider in detail the objectives and directions of each of the research projects, since it would have increased the volume of the article and not contributed to the major task. The major task was to provide a clear idea on the silver hake abundance dynamics as the basis of its fishery management by focusing attention on the main parameters of the life cycle. 


\section{Observations and Results}

\section{History, Catch Dynamics and Fishing Conditions}

Prior to 1963 no significant fishery for silver hake was carried out in the Scotian Shelf area. This species was of no interest to fishermen from Canada or other countries. In 1962 the first attempts to conduct a fishery directed towards silver hake were undertaken by USSR fishermen, and in 1963 the catch amounted to 123000 tons (Table 1). There was a sharp decrease thereafter and the lowest catches (total catch and catch-per-unit-effort) were recorded in 1966-68 (Tables 1, 2). In 1969 the catch sharply increased again and remained relatively high up to 1992 . In the last period of the fishery (1993-97) the catches again decreased sharply.

The catch-per-unit-effort (CPUE) data shown in Table 2 are very diversified and cannot be compared directly. Our purpose was only to demonstrate the trends during the longest possible period. In this case for data through 1977-97, the standardized catches per hour hauls (Showell and Bourbonnais, MS 1995) and catches per fishing day (field data of ZAPRYBA) appeared statistically comparable with a correlation coefficient of 0.89 , i.e. statistically significant at $99 \%$ level. During the 1966-68 period the stock was likely at a very low level. However, subsequently, a rapid increase in catches was observed. The data in 1973 are the most impressive when the USSR fishing fleet caught about 300000 tons of silver hake. This largescale fishery caused a concern for the Coastal State Canada and the resource management body ICNAF. Therefore, in the subsequent year, ICNAF made a decision to impose quotas for this fishery. Table 1 shows the ICNAF/NAFO Total Allowable Catch
(TAC) since 1974. Introduction of catch restrictions seems to be one of the main causes of total catch decrease which varied from 96000 to 116000 tons during 1974-76.

In 1977 an event happened which may be considered as the beginning of a new era in fisheries of Canada, USA and other countries, which actively fished in the Northwest Atlantic. In 1977 the 200mile economic zone was introduced. However, the non-Canadian fishery for silver hake on the Scotian Shelf, i.e. within the Canadian zone, was not eliminated, though it was restricted by regulatory measures implemented by Canada. During 1977-93 the total silver hake catch varied from 29000 to 88000 tons. During the 1990 s, the proportion of the total catch taken by Cuba increased sharply, and beginning in 1994 the silver hake fishery by Russian fishermen was discontinued. In 1994-97 the total catch varied from 8000 to 28000 tons.

Thus, two distinctly separate periods may be specified in the history of silver hake fishery in the Scotian Shelf area: before and after introduction of the 200-mile Exclusive Economic Zone (EEZ) in 1977. Fishery conditions during these two periods were naturally different. Before 1977 silver hake was fished over the entire shelf area, excluding the 12mile zone, during all seasons of the year and with no restrictions on mesh size in the trawl cod-end. From 1977, Canada introduced a boundary for silver hake fishing with small size mesh, referred to as the Small Mesh Gear Line (SMGL), which approximately coincided with $100-\mathrm{m}$ isobath. Silver hake fishing by bottom trawls with a cod-end mesh size not less than $60 \mathrm{~mm}$ was allowed only southward of that line.

TABLE 1. Total catch ('000 tons) of Scotian Shelf silver hake by all countries and USSR/Russia by year.

\begin{tabular}{|c|c|c|c|c|c|c|c|c|c|c|c|c|c|}
\hline Year & 1963 & 1964 & 1965 & 1966 & 1967 & 1968 & 1969 & 1970 & 1971 & 1972 & 1973 & & \\
\hline Total catch & 123.0 & 81.1 & 50.0 & 10.3 & 2.5 & 3.5 & 46.6 & 196.0 & 128.6 & 114.0 & 299.5 & & \\
\hline USSR/Russian catch & 123.0 & 81.1 & 50.0 & 10.3 & 2.5 & 3.4 & 46.3 & 169.0 & 128.6 & 113.8 & 298.5 & & \\
\hline Year & 1974 & 1975 & 1976 & 1977 & 1978 & 1979 & 1980 & 1981 & 1982 & 1983 & 1984 & 1985 & 1986 \\
\hline Total catch & 95.7 & 116.4 & 97.2 & 37.1 & 48.4 & 51.8 & 44.5 & 44.6 & 60.2 & 35.8 & 74.3 & 75.5 & 82.7 \\
\hline USSR/Russian catch & 95.4 & 112.6 & 81.2 & 33.3 & 44.1 & 45.1 & 41.0 & 41.2 & 47.3 & 27.4 & 57.4 & 56.4 & 66.6 \\
\hline Year & 1987 & 1988 & 1989 & 1990 & 1991 & 1992 & 1993 & 1994 & 1995 & 1996 & 1997 & & \\
\hline Total catch & 61.7 & 74.4 & 88.0 & 69.7 & 65.3 & 39.9 & 29.8 & 7.8 & 18.0 & 25.9 & 16.1 & & \\
\hline USSR/Russian catch & 41.3 & 65.3 & 72.9 & 55.4 & 40.8 & 11.8 & 7.1 & - & - & 0.7 & - & & \\
\hline
\end{tabular}


TABLE 2. Scotian Shelf silver hake catch-per-unit-effort by year.

\begin{tabular}{|c|c|c|c|c|}
\hline \multirow[b]{2}{*}{ Year } & \multicolumn{3}{|c|}{ Catches (tons) per hour trawling } & \multirow[b]{2}{*}{$\begin{array}{c}\text { Catches (tons) per vessel day of fishing } \\
\text { (operative data of ZAPRYBA)* }\end{array}$} \\
\hline & Halliday, 1973 & Fanning et al., 1987 & $\begin{array}{c}\text { Showell and } \\
\text { Bourbonnais, } 1995\end{array}$ & \\
\hline 1965 & 0.67 & & & \\
\hline 1966 & 0.22 & & & \\
\hline 1967 & 0.29 & & & \\
\hline 1968 & 0.15 & & & \\
\hline 1969 & 0.98 & & & \\
\hline 1970 & 1.58 & 2.86 & & \\
\hline 1971 & 1.13 & 2.05 & & \\
\hline 1972 & & 2.27 & & \\
\hline 1973 & & 2.99 & & \\
\hline 1974 & & 2.03 & & \\
\hline 1975 & & 1.82 & & \\
\hline 1976 & & 2.64 & & \\
\hline 1977 & & 2.38 & 1.88 & 29.5 \\
\hline 1978 & & 1.94 & 1.86 & 23.5 \\
\hline 1979 & & 2.07 & 2.47 & 27.4 \\
\hline 1980 & & 1.49 & 1.36 & 20.9 \\
\hline 1981 & & 1.80 & 1.62 & 26.6 \\
\hline 1982 & & 4.77 & 3.68 & 37.2 \\
\hline 1983 & & 2.40 & 1.88 & 30.5 \\
\hline 1984 & & 3.79 & 3.80 & 38.3 \\
\hline 1985 & & 3.30 & 4.07 & 38.9 \\
\hline 1986 & & 4.31 & 4.78 & 44.3 \\
\hline 1987 & & & 3.76 & 32.6 \\
\hline 1988 & & & 2.95 & 36.8 \\
\hline 1989 & & & 5.07 & 40.7 \\
\hline 1990 & & & 2.50 & 28.4 \\
\hline 1991 & & & 2.00 & 28.4 \\
\hline 1992 & & & 1.78 & 18.2 \\
\hline 1993 & & & 1.67 & 18.2 \\
\hline 1994 & & & 1.73 & - \\
\hline
\end{tabular}

* ZAPRYBA was the fishery organization of USSR, carried out the main silver hake fishery in northwestern Atlantic during major part of the period considered.

As a result of this measure the area available to the fishery decreased by about $90 \%$. In addition, strict restrictions were adopted for by-catch of other species (mostly cod, haddock and pollock). Silver hake fishing was allowed from 15 April to 15 November (inclusive) corresponding to the period when silver hake was most aggregated. However, spawning aggregations became mainly unavailable to fishing.

In 1994 the fishery was restricted even further when Canadian authorities, among other things, shifted the above-mentioned SMGL boundary to the depth approximately associated with the 190-m isobath (Branton et al., MS 1997). Under these conditions, as the data on silver hake aggregations show, a successful silver hake fishery could only be expected during the first half of the year (FebruaryApril).
Overall, after the implementation of 200-mile EEZ, conditions for successful catch of allocations provided by Canada to other countries sharply deteriorated. However, silver hake began to attract attention of Canadian fishermen then, and in the periods of high abundance, some increase of nonCanadian fishing fleet activity may be expected to have taken place in the area.

\section{Oceanographic Conditions}

Shelf waters of the Northwest Atlantic are considered to be among the most biologically productive ones in the world oceans. This is primarily related to oceanographic conditions, the major feature being the predominance of two powerful circulation systems (Fig. 1): warm water flow transported northeastwards by the Gulf Stream system, and Arctic water 


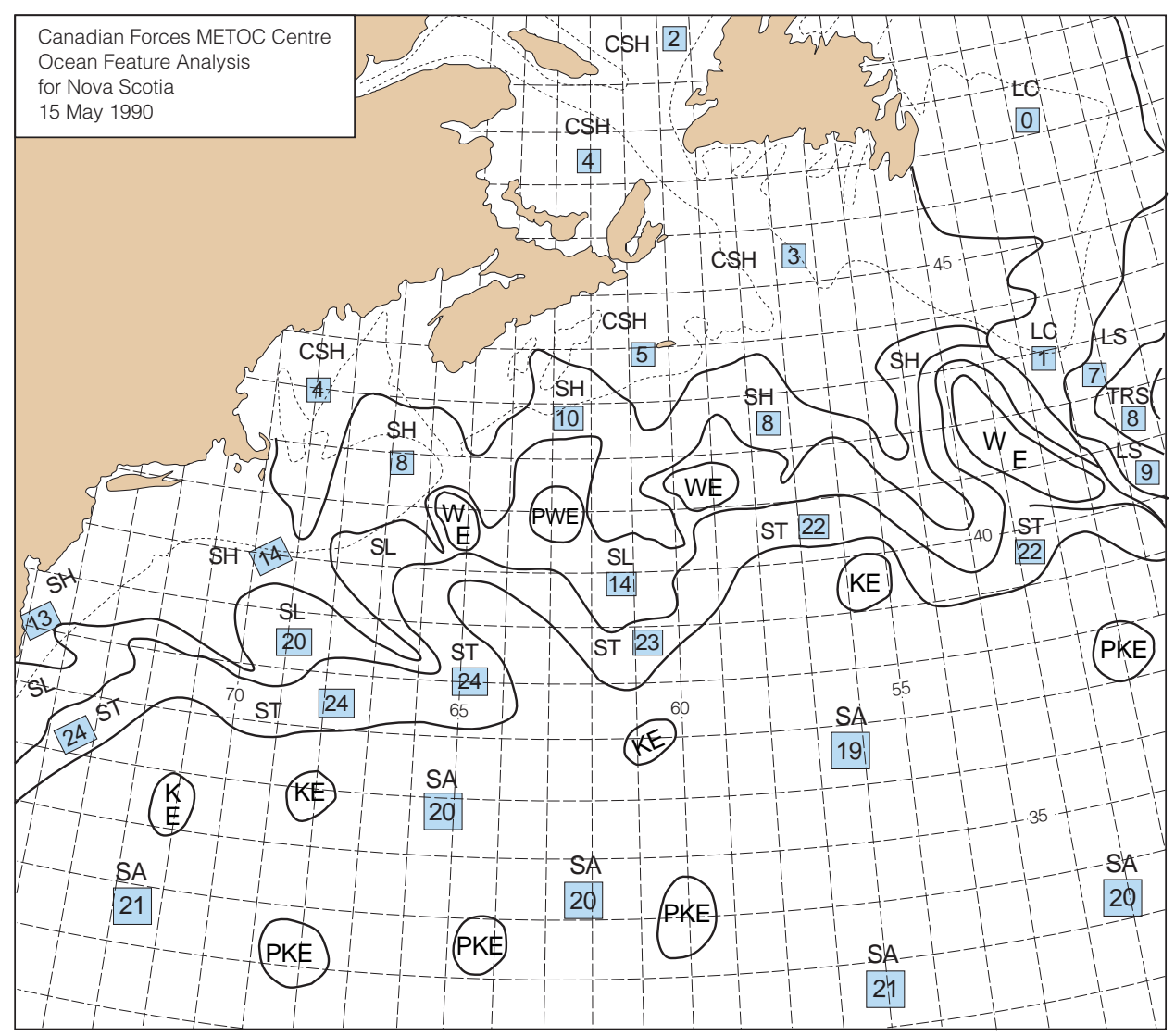

Fig. 1. An example of a Canadian Forces Meteorological Centre map of various water mass distribution at the surface and boundaries between them (ocean feature analysis) where: LC - Labrador current water, LS - Labrador Sea water, CSH- cold shelf water, SH - shelf water, SL - slope water, ST- Gulf stream front, SA - Sargassian Sea water, WE - warm rings, KE - cold rings, PWE - possibly warm eddy, PKE possibly cold eddy, TRS - transformed water, sea surface temperature shown in square boxes.

flow rich in nutrients transported southwards by the Labrador current. As a result of their interaction in the Northwest Atlantic shelf, including the Scotian Shelf, a three-layer water structure forms vertically (McLellan et al., 1953; McLellan, 1954 a, b; 1957; Bryantsev, 1962, 1963, 1967, Bryantsev and Filatov, 1969).

On the Scotian Shelf, the water mass of the upper layer of $0-50 \mathrm{~m}$ with temperatures of $4-16^{\circ} \mathrm{C}$ and salinities of 30.00-30.50\% forms under the impact of local climatic conditions, controlled mainly by the intraannual (seasonal) cycle of variability. The Cold Intermediate Layer (CIL) at 50-120 m with temperatures of $0-6.0^{\circ} \mathrm{C}$ and salinities of $32.50-33.50 \%$ originates from modified waters of the Labrador Current, transported to the shelf from Laurentian Channel. The near-bottom water layer in the shelf, located below $120 \mathrm{~m}$, consists of slope waters originating from modified Gulf Stream waters with temperatures of $6-14^{\circ} \mathrm{C}$ and salinity above $33.50 \%$.

In the Scotian Shelf ecosystem, the life cycles of the various fishes are related to the different water masses. For example, cod, herring, haddock, pollock and other relatively cold-water species prefer the intermediate cool layer approaching the bottom in the shelf areas with depths from 50 to $120 \mathrm{~m}$, while species such as silver hake and red hake prefer the warm nearbottom layer which extends to depths more then 120 $\mathrm{m}$ on the shelf. On the Scotian Shelf and in adjacent ocean waters hydrological fronts are formed which separate waters with different hydrological characteristics and result in different species compositions and abundance. Such fronts as Gulf Stream front (ST) and the front between warm Slope water (SL) and Shelf 
water (SH), also called shelf-slope front, are the most developed ones. Also, the boundary between shelf upper layer (local water) and more coastal cool shelf water (CSH) (Fig. 1) is important.

For the silver hake population, the spatial location of the boundary between warm slope waters and cool shelf waters is important, since the warm water mass in the layer of $120-500 \mathrm{~m}$ becomes the environment for this species. Slope water from offshore intrudes into the shelf area through the relatively deep trough between Lahave and Emerald Banks, and distributes in the deep-water shelf area with the depth over 120 m (Fig. 2). Where Slope water meets with Shelf waters at the outside shelf boundary along the slope, a hydrological front is formed which becomes stronger at the depth of $50 \mathrm{~m}$, since warm Slope water with temperatures of $7-12^{\circ} \mathrm{C}$ directly underlies the CIL, and the temperature gradient at the boundary may approach $0.5^{\circ} \mathrm{C}$ per naut. mile and more.

Long-term studies by AtlantNIRO of hydrological conditions, and the biological state and distribution of silver hake catches from commercial and research vessels have shown that such life-cycle stages as over- wintering and feeding silver hake occur in nearbottom Slope water. However, during mass spawning they prefer warm (above $10^{\circ} \mathrm{C}$ ) shallow waters off Sable Island at depths of 30-40 m, i.e. water of the upper layer with salinity significantly lower than that of the Slope water.

Silver hake distribution on the shelf is generally restricted by the deep-water area, sometimes called the Scotian Trough, that extends eastwards to $61^{\circ} \mathrm{W}$ (Fig. 2). Silver hake distribution along the shelf slope is defined by several areas where warm Slope water comes in contact with the shelf. Usually they do not form dense aggregations eastwards of $58^{\circ} \mathrm{W}$, since the Slope waters move off the slope to the open sea in that area. Thus, it can be assumed that the boundary of the water mass typical to silver hake on the Scotian Shelf is the boundary of its distribution area. This boundary on the shelf is located at $61^{\circ} \mathrm{W}$ at the end of the Scotian Trough, while at the slope it is located at about $58^{\circ} \mathrm{W}$. However, it is known that individual silver hake occur far eastwards at the southwestern slopes of Grand Bank, which may be the result of formation of strong Gulf Stream meanders reaching warm waters of the Bank slope. The evidence that the

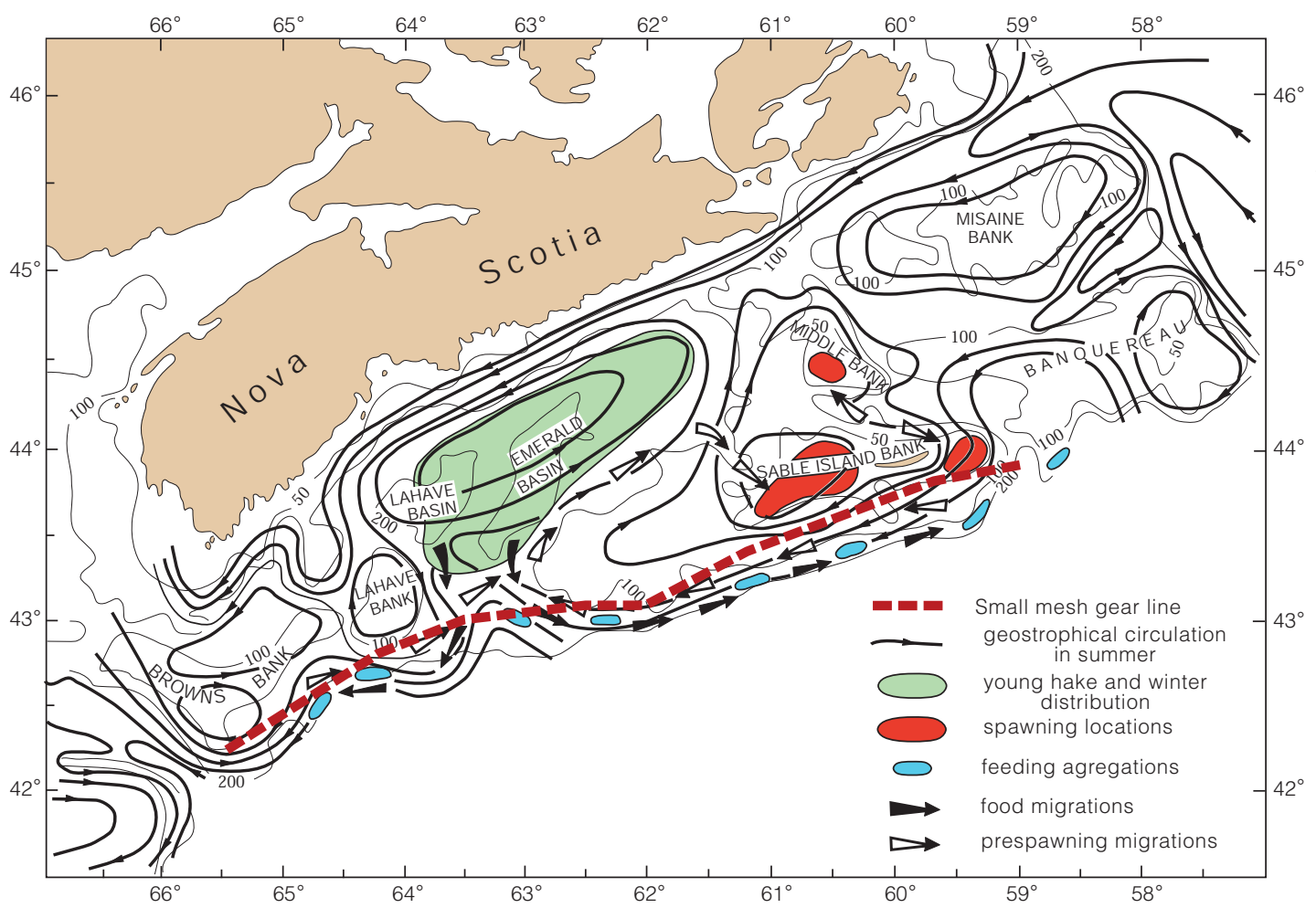

Fig. 2. Summer type of geostrophic circulation and silver hake distribution on the Scotian Shelf (from Sigaev, 1978). 
Scotian Shelf silver hake population occurs at the northeastern boundary of the species distributional area, suggests that environmental conditions, primarily oceanographic ones, may be crucial at various stages of their life cycle and may significantly affect the dynamics of this population.

\section{Water Circulation and its Impact on Distribution}

Water mass dynamics in the shelf area and the complex bottom relief form the circulation field that is closely related to the distribution of oceanographic features, production processes and life cycles of fishes. Summer current patterns, which define silver hake feeding and spawning conditions, are shown in Fig. 3 as a geostrophic version reflecting occurrence of quasi-stationary eddies within the shelf (Sigaev, 1978). Also, silver hake migrations are shown based on data from Karasiev (1975). The figure shows that feeding and spawning aggregations occupy the shelf slope from Banquereau Bank to Browns Bank, being distributed in the flow directed southwestwards along the shelf slope. Mass spawning occurs mainly on the shallows of Sable Island (during some years also in Middle Bank area) during July to August where the anticyclonic gyre is formed in summer. Sigaev (1978) has suggested that the ecological role of the gyre is as follows: eggs during incubation, and larvae during development before independent feeding, are retained by the gyre in the upper $30-40 \mathrm{~m}$ layer warmed to $10-17^{\circ} \mathrm{C}$. These gyres also promote production and concentration of food for silver hake, and larvae of other species, which is an important factor during the transition from larval stage to independent feeding. Sigaev (1978) also suggested that in autumn, after spawning, larvae are transported by currents into the zone of the near-by quasi-stationary cyclonic gyre, located above the deep-water shelf area, where they develop to the stage of fry and migrate to the nearbottom layer. The bulk of fry and juvenile silver hake (and partially adult hake) become distributed in the warm near-bottom layer within the gyre during overwintering. Favourable temperature and feeding conditions are provided by the periodical inflow of slope water and by the high abundance of euphausiids - the major food item of silver hake. According to Sameoto and Cochrane (MS 1996), euphausiid abundance in the Scotian Shelf area is highest in the Scotian Trough, where it averages 10 g/sq.m.

\section{Distribution during First Year of Life}

\section{Eggs and larvae}

The level of recruitment is the major characteristic in determining the variation in abundance of commercial fishes and invertebrates, and is one of the most important parameters for stock assessment and yield prediction. To provide regular data on silver hake recruitment, AtlantNIRO, (USSR/Russia), and Bedford Institute of Oceanography (BIO) (Department of Fisheries and Oceans, Canada), within the framework of bilateral agreements and upon the recommendations of ICNAF (until 1978) and NAFO Scientific Council (thereafter), carried out special trawling surveys from 1978 to 1997 to estimate 0 -group abundance.

In the initial stage of research, in 1978-80, surveys of juvenile silver hake were preceded by surveys for egg and larval density and distribution, zooplankton distribution and hydrological observations carried out annually in August-October. Methods used for these egg and larval surveys and the results obtained are described in Noskov et al. (MS 1978, MS 1979, MS 1982) (data on eggs and larval distribution and abundance).

It was found that major silver hake spawning occurred in the central part of the Scotian Shelf at surface water temperatures of $12-18^{\circ} \mathrm{C}$ between Emerald Bank and western Sable Bank. Silver hake egg distribution was determined by summer anticyclone circulation, which was observed in the areas of Emerald Bank, Middle Bank and Sable Island Shallows (Fig. 1 and 2) at the boundary of water upwelling and downwelling during August. Eggs and larvae (spawning area boundary at $65-67^{\circ} \mathrm{W}$ ) gradually drift southwestwards and do not tend to get transported outside the shelf area.

Egg and larval survey data for August-September 1978 provide an example of egg and larval distribution (Fig. 3), showing aggregations of 1000 individuals per haul westward of Sable Island over depths less than $80 \mathrm{~m}$ and at surface water temperatures of 14$18^{\circ} \mathrm{C}$.

\section{Juveniles (0-group)}

Russian scientists jointly with Canadian scientists carried out the autumn 0-group surveys aboard AtlantNIRO vessels from 1978 to 1991 under an intergovernmental agreement. Since 1993 the surveys have been carried out on BIO vessels with Russian scientists involved. In 1992 no survey was carried out, and it was the only gap in observations series during 20 -year period. This survey series ended after the 1997 survey.

These autumn 0 -group survey objectives were carried out in October-November based on the 

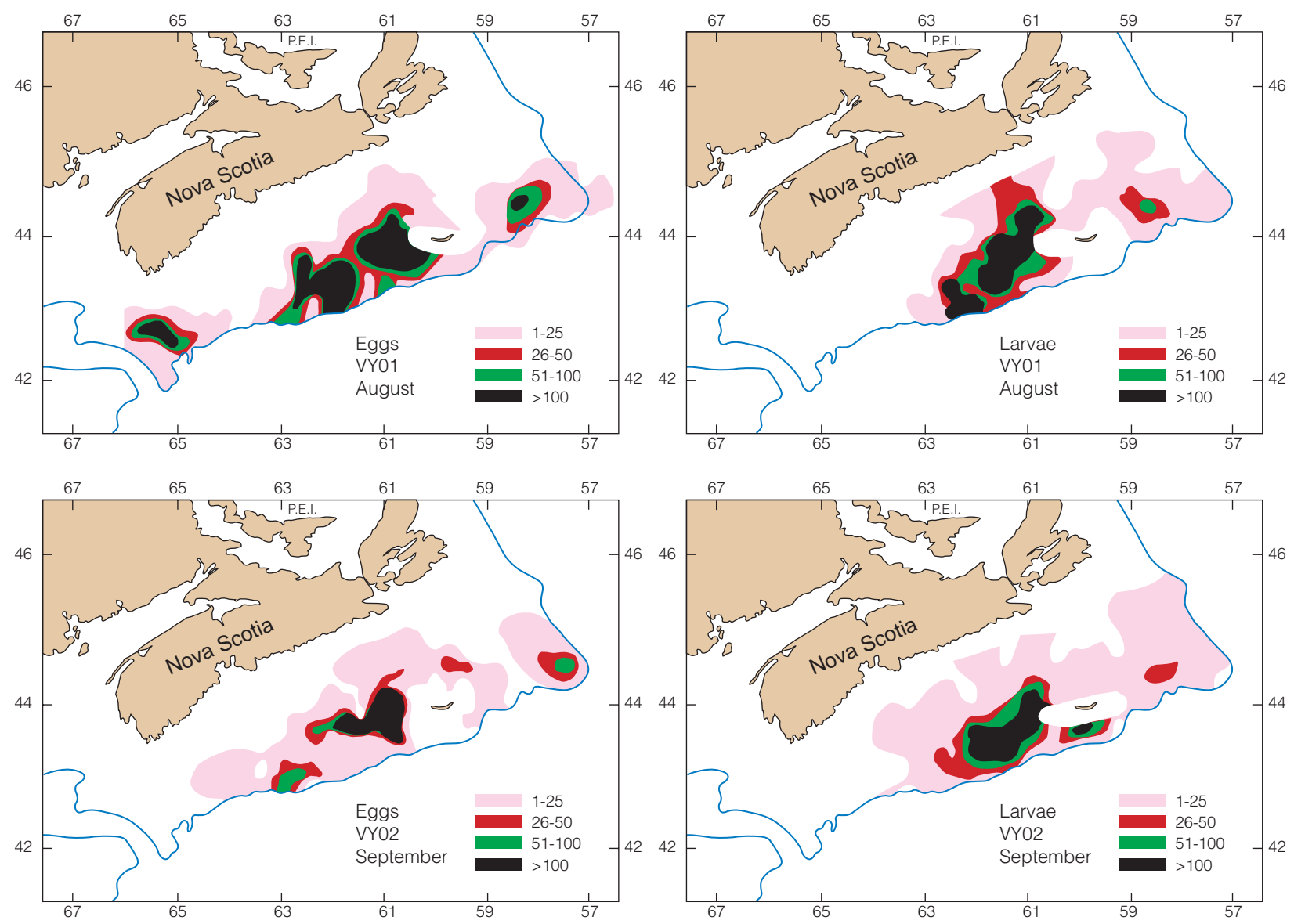

Fig. 3. Distribution of Scotian Shelf silver hake eggs and larvae in 1978 (individuals $/ \mathrm{m}^{2}$ ) from Noskov et al. (MS 1979) as reillustrated by O'Boyle et al. (1984).

principle of stratified-random selection of stations (Grosslein, 1969; Doubleday, 1981). The surveys used a $13.6 \mathrm{~m}$ juvenile trawl during $1978-80$, and the IGYPT trawl for juvenile gadoids was used in 1981 and subsequent years. Koeller (1981) described the transfer to the new sampling strategy.

It should be noted that changes made in these 0group silver hake survey methods were not limited to only fishing gear. In 1981 the near-bottom hauls, which were conducted on a twenty-four-hour basis, were replaced with three-stage oblique ones carried out only in darkness. After 3-4 years, when the minimum amount of material required for comparison was available, the analysis of survey data obtained using both old and new methods was carried out (Koeller et al., 1984, 1986a; Noskov and Sherstyukov, MS 1984, 1985). The analysis concluded that the data obtained before 1981 could not be used along with the data from subsequent years as an indication of relative abundance of silver hake year-classes. In the juvenile distribution analysis the data for the whole observation period 1978 to 1991 inclusive were used, while indices of abundance were analyzed from 1981 to 1996 inclusive.

The survey data provided information about silver hake distribution in relation to water temperature. In general juvenile silver hake in the Scotian Shelf area were observed between $65^{\circ}$ and $59^{\circ} 30^{\prime} \mathrm{W}$, mainly within the depth range of 100-200 m (Table 3) and temperature ranges of $5-12^{\circ} \mathrm{C}$. Dense juvenile aggregations (above 100 individuals per haul) were usually found in the areas with apparent temperature gradients which occurred as a result of interaction between quasi-stationary warm Slope water and the cold intermediate layer. Examples of silver hake distribution in warm (1985) and cool (1987) years (Sigaev and Rikhter, 1996) are shown in Fig. 4.

In 1985 juveniles were distributed through the entire shelf within a wide range of near-bottom temperature ranging from 6 to $12^{\circ} \mathrm{C}(89 \%$ of the total 

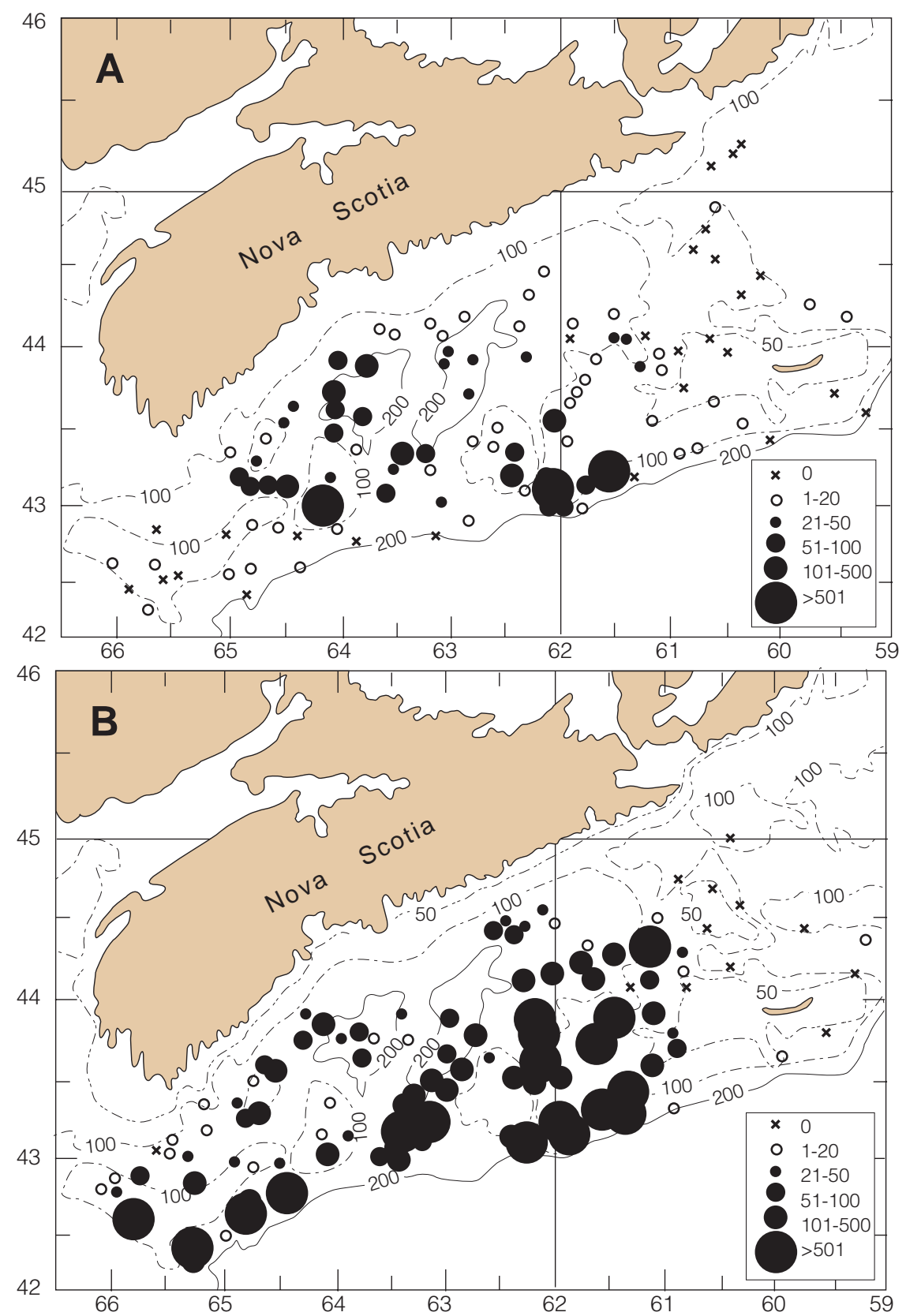

Fig. 4. Distribution of Scotian Shelf 0-group silver hake (individuals/haul) in 1987 (A) and 1985 (B). (A from Sigaev et al., MS 1988; B from unpubl. data by Sherstyukov).

catch in 1985). However, the most dense aggregations of young fish were observed within the zone of highest temperature gradients southward of Browns Bank and Sable Island Bank as well as in the shallow area of the shelf at depths up to $100 \mathrm{~m}$ where intrusion of warm slope water $\left(8-10^{\circ} \mathrm{C}\right)$ was observed (unpublished data of AtlantNIRO). Maximum mean catch per haul exceeded 1100 individuals (Koeller et al., 1986b).
During cold years, juveniles mainly concentrated within a narrow range of near-bottom temperature from $6^{\circ}$ to $8^{\circ} \mathrm{C}(58 \%$ of the total catch in 1987) (Sigaev et al., MS 1988). In the relatively cold year 1987, a weak inflow of warm slope waters was observed and gradient zones were found within restricted shelf areas along the slope and in the southern La Have Bank. Most of the juvenile catch (54-76\% except in 1979) was taken over intermediate depths 101-200 m 
(Table 3). Only a few juvenile catches exceeded 500 individuals/haul while most catches were below 50 individuals/haul. In 1979 (which was also a cool year) highest densities occurred in the slope area at depths below $200 \mathrm{~m}$, where $90 \%$ of the catch was taken.

Therefore, the relationship between juvenile hake distribution in autumn and water temperature in the Scotian Shelf area seems evident. Hence it may be assumed that warming increase the area of 0 -group distribution and facilitates better survival of young fish, i.e. strong year-classes formation in this silver hake population. In this case cooling will naturally have the opposite effect.
Studies of diurnal vertical migrations of juvenile silver hake in relation to the water thermal structure, amount of light and feeding intensity, were conducted to improve the reliability of 0 -group survey results. For this purpose along with routine surveys special diurnal stations were carried out in some occasions. On the basis of literature on vertical migration of plankton-feeding fishes, it was assumed that the night ascent of juveniles into the upper water layers is related to their feeding upon Euphausiidae (Meganyctiphanes norvegica), which also perform diurnal migrations (Mauchline and Fisher, 1969).

On the basis of research carried out in October 1980 (Koeller, MS 1981) it was apparent that 0-group

TABLE 3. Young silver hake abundance (in numbers and $\%$ of total catch) in the catches taken by fry trawl relative to bottom depth (1987 data from Sigaev et al., MS 1988; for 1979, 1981 and 1985 years are unpublished AtlantNIRO data; 1988 and 1989 data from Sherstyukov, 1990a and 1991a, respectively)

\begin{tabular}{|c|c|c|c|c|c|c|c|c|}
\hline Year & Depth (m) & $\begin{array}{l}\text { Total catch } \\
\text { (in numbers) }\end{array}$ & $\%$ & $\begin{array}{c}\text { Average catch } \\
\text { per haul } \\
\text { (in numbers) }\end{array}$ & $\begin{array}{l}\text { Number of hauls } \\
\text { without catch }\end{array}$ & $\%$ & $\begin{array}{c}\text { Total number } \\
\text { of hauls }\end{array}$ & $\%$ \\
\hline \multirow[t]{3}{*}{1979} & $0-100$ & 105 & 1 & 3 & 18 & 54 & 33 & 33 \\
\hline & $101-200$ & 871 & 9 & 19 & 15 & 33 & 46 & 46 \\
\hline & $201-300$ & 9091 & 90 & 433 & 7 & 33 & 21 & 21 \\
\hline Total & & 10067 & 100 & 101 & 40 & 40 & 100 & 100 \\
\hline \multirow[t]{3}{*}{1981} & $0-100$ & 8238 & 16 & 317 & 2 & 8 & 26 & 27 \\
\hline & $101-200$ & 38598 & 76 & 654 & 2 & 3 & 59 & 60 \\
\hline & $201-300$ & 3813 & 8 & 293 & 2 & 15 & 13 & 13 \\
\hline Total & & 50649 & 100 & 517 & 6 & 6 & 98 & 100 \\
\hline \multirow[t]{3}{*}{1985} & $0-100$ & 9162 & 33 & 295 & 6 & 19 & 31 & 27 \\
\hline & $101-200$ & 10095 & 54 & 243 & 4 & 6 & 62 & 55 \\
\hline & $201-300$ & 3783 & 13 & 189 & 6 & 30 & 20 & 18 \\
\hline Total & & 28040 & 100 & 248 & 16 & 14 & 113 & 100 \\
\hline \multirow[t]{3}{*}{1987} & $0-100$ & 2330 & 25 & 73 & 12 & 37 & 32 & 29 \\
\hline & $101-200$ & 6500 & 68 & 114 & 7 & 12 & 57 & 53 \\
\hline & $201-300$ & 689 & 7 & 34 & 10 & 50 & 20 & 18 \\
\hline Total & & 9519 & 100 & 87 & 29 & 27 & 109 & 100 \\
\hline \multirow[t]{3}{*}{1988} & $0-100$ & 280 & 2 & 9 & 13 & 42 & 31 & 28 \\
\hline & $101-200$ & 15180 & 92 & 257 & 8 & 13 & 59 & 53 \\
\hline & $201-300$ & 960 & 6 & 46 & 6 & 28 & 21 & 19 \\
\hline Total & & 16420 & 100 & 148 & 27 & 24 & 111 & 100 \\
\hline \multirow[t]{3}{*}{1989} & $0-100$ & 541 & 6 & 15 & 11 & 10 & 37 & 34 \\
\hline & $101-200$ & 7858 & 84 & 140 & 6 & 5 & 56 & 51 \\
\hline & $201-300$ & 908 & 10 & 53 & 2 & 2 & 17 & 15 \\
\hline Total & & 9307 & 100 & 85 & 19 & 17 & 110 & 100 \\
\hline
\end{tabular}


fish are relatively uniformly distributed within the water column at night and leave the pelagic layer in the daytime. In a larval study by Sherstyukov and Nazarova (1987) in November 1985, highest catches were observed in the pelagic zone at night from twilight to dawn. In the daytime no fry were found in the pelagic layer. Small numbers of juveniles occurred in the near-bottom layer also in daytime, the major aggregations presumably occurring very close to the bottom (Bowman and Bowman, 1980). However, sometimes variations of that distribution pattern were observed. A significant catch of juvenile fish was taken in the daytime in pelagic layer at $65 \mathrm{~m}$ (Sherstyukov and Nazarova, 1987). Also, at night juvenile fish did not always migrate to the upper layers. For example, in October 1983 a big aggregation of 0-group fish was observed near the bottom during one night (Noskov and Sherstyukov, MS 1984).

In December 1989-January 1990, scientists of AtlantNIRO carried out an extraordinary juvenile survey (Sherstyukov, 1991a). The results allowed us to suppose that in winter 0-group silver hake distribute primarily near the bottom in deep depressions of the shelf and in some areas of the slope within the optimal temperature range. Additionally, this did not undertake the diurnal vertical migrations, which are observed in October-November. In any case, the results of the survey showed a sharp decrease of juvenile abundance in the pelagic layer as compared to the autumn period.

Length compositions of juveniles, based on the surveys carried out in October-November in 198191 are presented in Table 4. Mean length varied from 3.3 to $6.4 \mathrm{~cm}$. However, during the survey period the length compositions remained almost similar. The variations in juvenile average length by year are likely the result of considerable variability in the mass spawning period.

Attention was paid to the possibility of using the data on young silver hake abundance as indications of year-class abundance (Koeller et al., MS 1986a,b; Sherstyukov, MS 1991a), and the scientists of both countries concluded that the results of 0-group surveys may be used as preliminary indicators of year-class strength.

\section{Age 1 Year and Older}

As was noted earlier for the younger stages, older silver hake is a warm-water species and prefers warm slope water of the shelf slope and deep-water shelf area (Sauskan, MS 1964; Sarnits and Sauskan, MS 1966; Sigaev, MS 1990; 1995, 1996b). Water temperature typical for silver hake is $7^{\circ} \mathrm{C}-10.5^{\circ} \mathrm{C}$,

TABLE 4. Length composition of 0-group silver hake $(\mathrm{cm})$ according to data of AtlantNIRO trawl surveys on the Scotian shelf (joint Soviet-Canadian program, unpublished data of AtlantNIRO).

\begin{tabular}{llccc}
\hline \hline Year & \multicolumn{1}{c}{ Survey period } & $\begin{array}{c}\text { Length }(\mathrm{cm}) \\
\text { range }\end{array}$ & $\begin{array}{c}\text { Predominant } \\
\text { group }\end{array}$ & Average \\
\hline 1981 & 19 October -7 November & $2-10$ & $5-6$ & 5.8 \\
1982 & $1-14$ November & $2-8$ & $3-5$ & 4.1 \\
1983 & 16 October-23 November & $2-10$ & $4-6$ & 5.9 \\
1984 & 15 October-28 November & $2-10$ & $4-7$ & 6.4 \\
1985 & 18 October-13 November & $2-11$ & $4-7$ & 6.0 \\
1986 & 18 October-6 November & $2-9$ & $4-6$ & 5.3 \\
1987 & 18 October-13 November & $2-7$ & $2-4$ & 3.3 \\
1988 & 23 October -27 November & $2-10$ & $4-7$ & 5.6 \\
1989 & 19 October -13 November & $2-10$ & $5-7$ & 5.8 \\
1990 & 18 October-18 November & $2-10$ & $5-6$ & 5.6 \\
1991 & 7 November-3 December & $2-10$ & $5-6$ & 5.7 \\
\hline
\end{tabular}


however, small numbers may be observed at temperatures below $7^{\circ} \mathrm{C}$. The plot (Fig. 5) of research survey catches against near-bottom temperature based on the data of trawling and hydrological stations carried out during ecological surveys by AtlantNIRO in 1990 (Sigaev, 1995), supports the these conclusions. Dense aggregations of older sliver hake at the shelf slope are usually formed within the shelf-slope temperature front, where it comes in contact with the slope or enters onto the shelf. The front areas with the highest temperature gradients are more favourable to aggregation formation (Fig. 6). The figure shows that northwards of the front, in the cool water of the intermediate layer, no silver hake occurred in the catches.

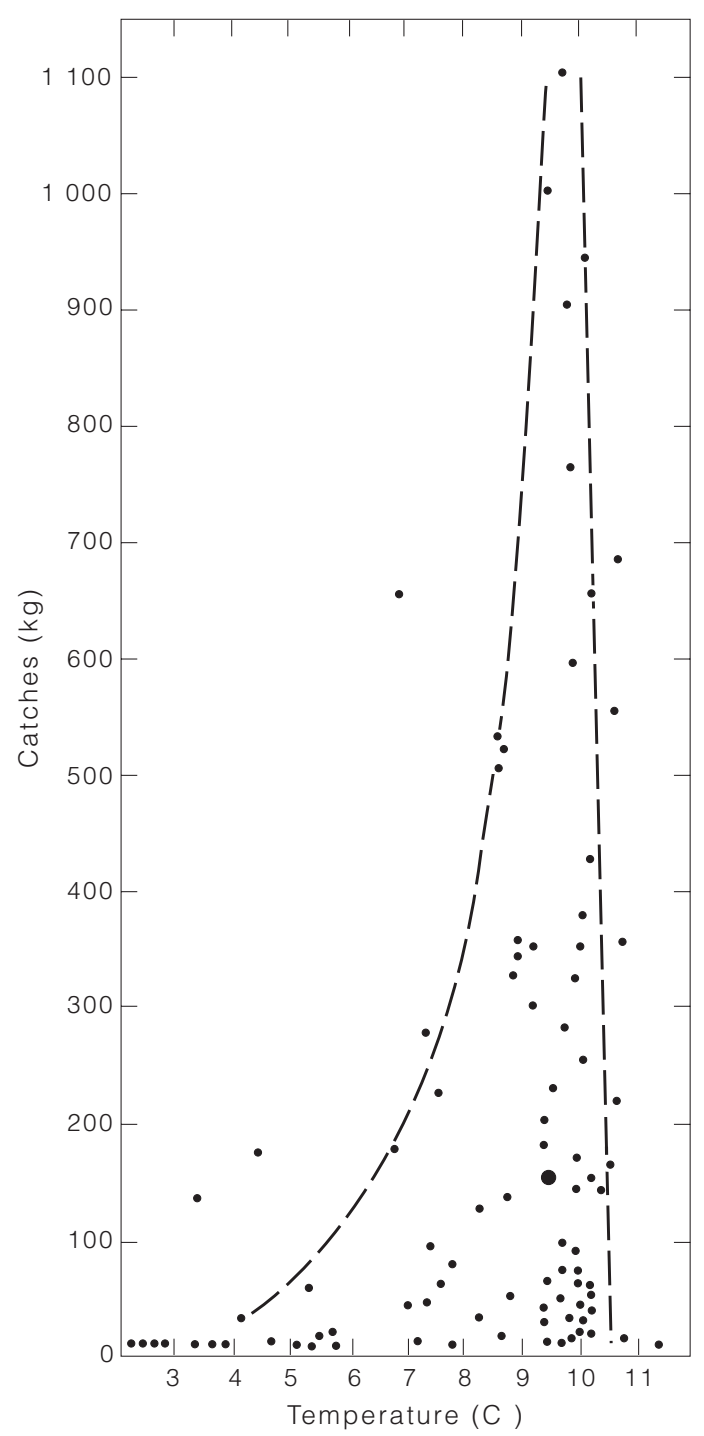

Fig. 5. Relation between research survey catches of silver hake and near-bottom temperature on Scotian Shelf (from Sigaev, 1995).
Spatial and temporal variations of hydrographical fronts in the Northwest Atlantic affect both the distribution and density of silver hake aggregations. As an example, we may compare average daily catches obtained by the Russian commercial vessels in AprilJuly 1990 (Sigaev, 1991, AtlantNIRO, unpublished report) within the slope zone and localization of the water mass boundaries during the same time period (Fig. 7). The figure shows that main periods of change in average daily catch, coincides in time with latitudinal changes in the three boundaries. Besides, as shown from the analysis of the Russian commercial catches of April-July 1990, catch-per-unit-effort estimates do not depend on the number of vessels in the fishery, i.e. if the water-mass boundary was favourable (or unfavourable) for silver hake aggregation formations in the slope area, the catchper-unit-effort decreased (or increased) irrespective of the number of vessels engaged in the fishery.

\section{Distribution of Silver Hake and Forage Zoo- plankton in Relation to Mesoscale Circulation on the Slope}

Detailed study of mesoscale oceanographic features in the area of the shelf-slope front shows eddy formation occurs northwards of the front. Figures 8 and 9 (from Sigaev, 1996b) show examples of temporal variability in near-bottom temperature fields and water circulation in relation to research survey catches of silver hake. Decreased catches were observed during the second and the fifth surveys (panel 2 and 5 in Fig. 8 and 9, respectively) in the study area, when the central part of the gyre was located at the slope, and the current between two adjacent gyres was directed northwards of the slope. In such cases a decrease of temperature gradients at the front is observed.

Increased catches were noted in the first, fourth and sixth surveys at times when the gyre's southern periphery was located at the slope increasing the temperature gradients. Direct impact of such a gyre upon silver hake distribution at the slope seems to be rather restricted. The impact is likely greater on the formation and distribution of forage zooplankton patches. All conditions required for the latter development are available (advection of water with high nutrient content to the slope as a result of slope waters overflow in the shelf area, upwelling processes resulting in development of phyto- and zoo-plankton). Therefore a permanent zone of high biological production exists along the shelf slope. Figure 10 shows examples of advection of water with high nutrient content. 

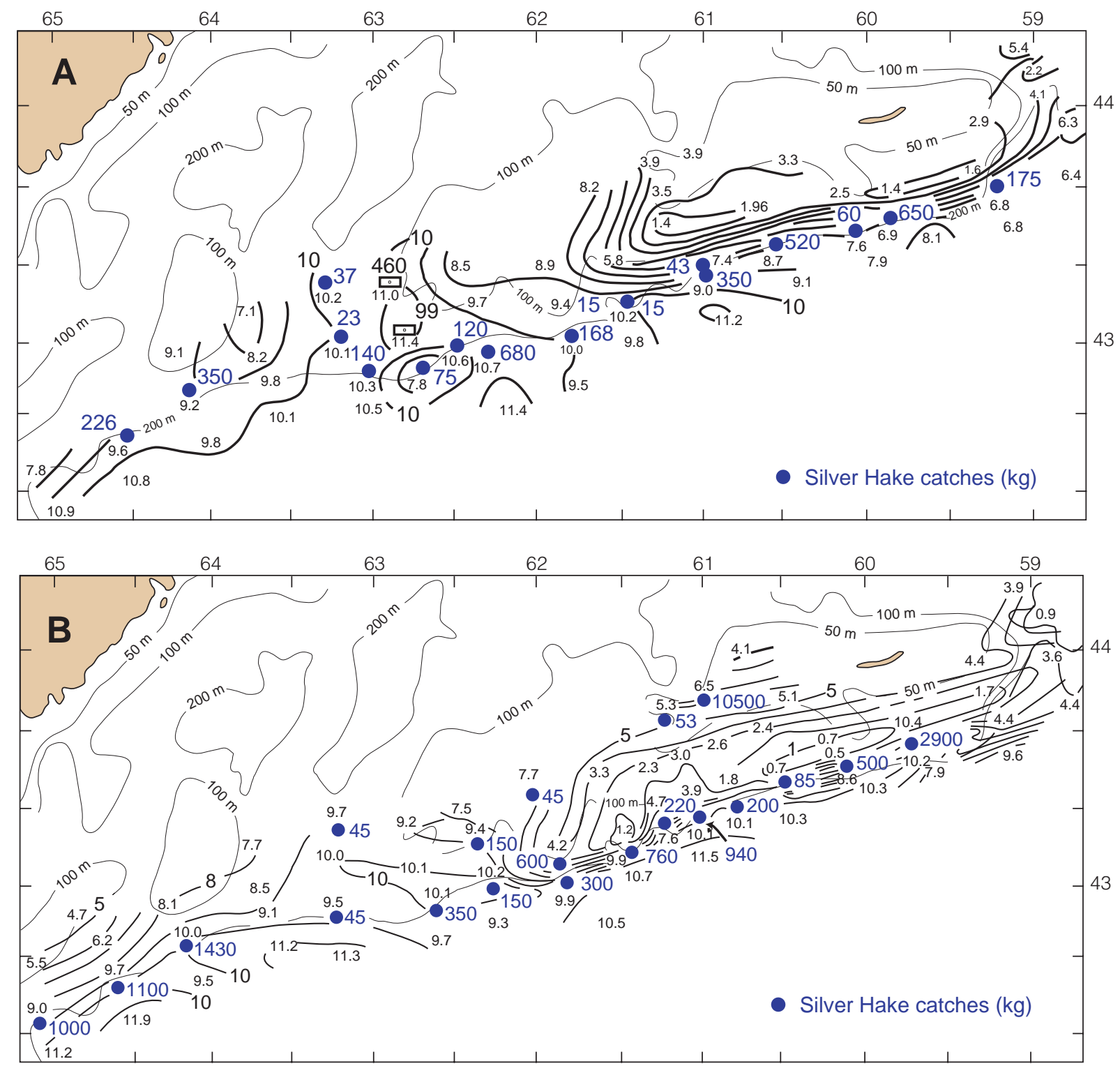

Fig. 6. Distribution of near-bottom temperature and silver hake catches during research surveys on Scotian Shelf during 20-31 May 1990 (A) and 07-17 July 1990 (B) (from Sigaev, 1995).

Research on feeding activities of silver hake have shown that large zooplankton (krill) constitutes a significant proportion (30-50\%) of its food spectrum (Clay et. al., 1984; Vinogradov, 1984; Waldron, 1992). It has also been shown that diurnal vertical migrations of silver hake are related to diurnal vertical migrations of euphausiids (Vinogradov, MS 1993).

Ecological surveys at the shelf slope, including observations obtained by AtlantNIRO in 1988 and 1990, allow a comparison to be made between research catches and species composition of forage zooplankton. Comparative analysis of silver hake catches and zooplankton density from 174 bottom trawl and plankton net hauls (i.e. plankton net attached to the upper part of trawl) have shown that silver hake catch size related to more on the size of zooplankton species present than on the overall density (Sigaev, 1995). Silver hake catches were low when small plankton forms (Calanoida) predominated (Fig. 11), while catches were higher when larger forms (e.g. Themisto spp.) were present. Greatest catches were obtained where large zooplankton (Euphausiidae) predominated (Fig. 12). Thus, availability of the 


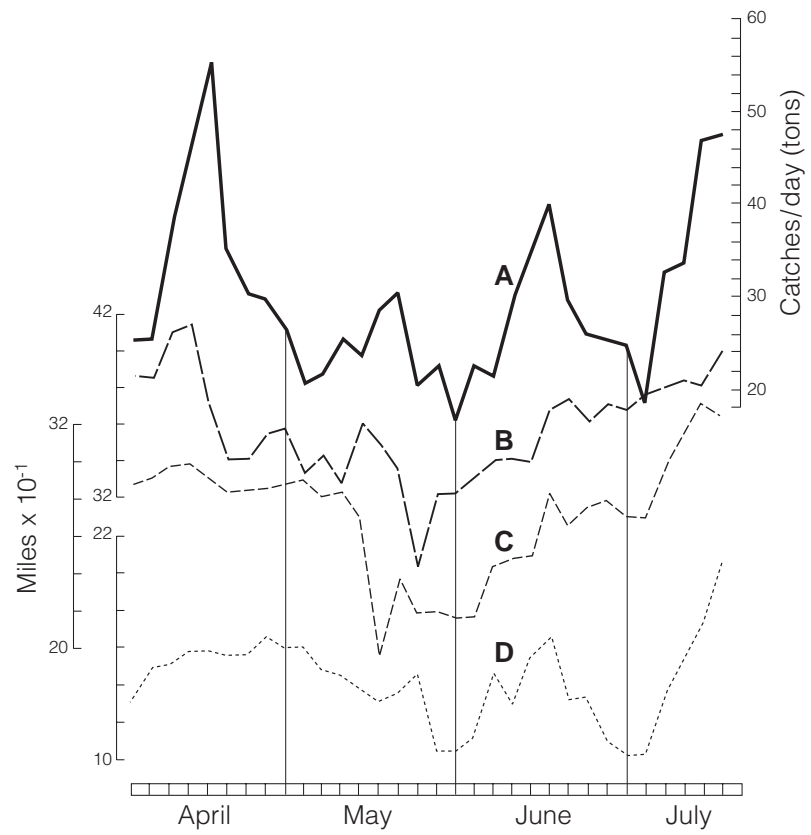

Fig. 7. Fluctuations of average daily silver hake catches in tons (A), indices of boundaries locations of cold shelf water (B), of slope water $(\mathbf{C})$ and Gulf Stream front (D) in April-July 1990. Catch data from Russian fishing vessels are reduced to the dates of facsimile map appearances of "Ocean feature analysis", produced by Canadian Forces Meteorological Centre (Sigaev, 1991, unplubl. report).

preferred food may be considered as the second important factor (after temperature) affecting silver hake distribution.

Analysis of stomach contents from samples taken from the surveyed slope area, shows that large silver hake at the modal length of 28-33 cm feed mainly on the larger plankton, Euphausiidae, and very rarely on the smaller form, Calanoida. Therefore, it has been assumed that feeding and pre-spawning silver hake in their middle length range also form aggregations in areas of concentrations of large zooplankton (Vinogradov, 1984; Sigaev, MS 1985).

The distribution of zooplankton patches, and their species composition, correspond to the location of eddies near the bottom and to the direction of currents. Modeled near-bottom flows (Fig. 9) indicated the possibility of Calanoida being transported to the front, from the cool water of the intermediate layer. These Calanoida may accumulate in the areas of hydrological fronts and be transported along the front, causing unfavourable feeding conditions for silver hake.
Similarly, the large zooplankton, Euphausiidae, typical of Slope waters also may concentrate in the front area and be transported northward of the front into temperature conditions unfavourable to silver hake. It would seem that the best forage conditions occur in the slope areas where there are no flows crossing the slope, i.e. when the current is along the slope. The hydrological front in such a case is stable and has the role of forming a "liquid wall", preventing plankton transport into the open sea.

\section{Biological Characteristics}

\section{Age-length composition in commercial catches}

Data on silver hake length composition in commercial catches in 1968-93 are presented in Table 5 (data from AtlantNIRO sampling performed on commercial vessels). Data on average length within this 25-year period show an increasing tendency from the late-1960s to the early-1980s and a decreasing tendency during the subsequent years. In general however, the predominant length groups within the period under discussion remained stable.

Silver hake 24-37 cm in length constituted the bulk of fishery in each year. Average length varied from 27.2 to $31.5 \mathrm{~cm}$. Minimum and maximum lengths varied more widely by year. This was especially true for maximum length, which is not affected by anthropogenic factors influencing the size of fish in the catch (mesh size, lack of market demand, etc.). Concerning the occurrence of extreme lengths (of adult fish) in the catches, it is most probable that this is affected by silver hake behaviour and distribution, which determines its availability to fishing gear. Variability of growth rate also may play a role, as well as fishing pressure, which in some years may result in large fish disappearing from catches.

Before considering characteristics of silver hake age composition in commercial catches, it is necessary to describe briefly the history of attempts to standardize age readings performed by Russian and Canadian scientists. In the framework of bilateral cooperation, serious attention was paid to this problem since correct age reading is very important for stock assessment and catch prediction. Three joint working group meetings of scientists from USSR, USA and Canada were held in 1976-78 (ICNAF, MS 1976; MS 1977; MS 1978). In 1980 a manual on silver hake age determination, using otoliths, was published (Hunt, 1980). But this did not result in elimination of deviations in age interpretation. A regular exchange of otolith samples with subsequent comparative 


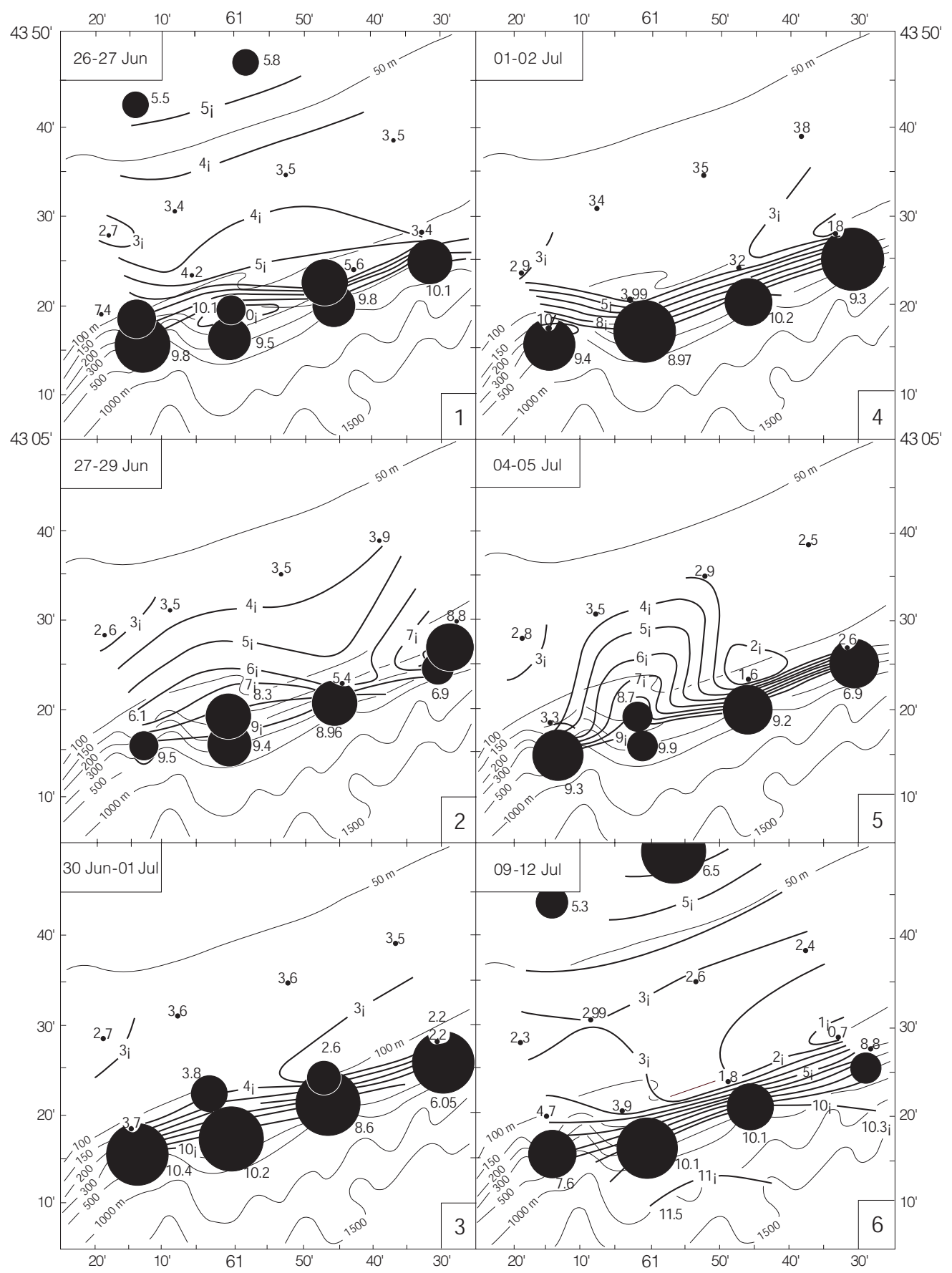

Fig. 8. Distribution of silver hake catches and near-bottom temperature within the research survey study area during 26 June-12 July 1990 (from Sigaev, 1996).

analysis of age estimates obtained independently in USSR and Canada was established with the aim to minimize differences (Hunt, MS 1985; MS 1986; MS 1987a; MS 1989; MS 1991; Senina and Stulova, MS 1986). Occasionally, Cuban scientists took part in the exchange program (Dominguez and Varea, MS 1986).
In March 1990 another joint working group meeting was held in Murmansk, USSR. It was the last attempt in the long history of the international cooperation aimed at resolving the issue of Scotian Shelf silver hake age estimation. In general through these working groups and otolith exchanges a high 


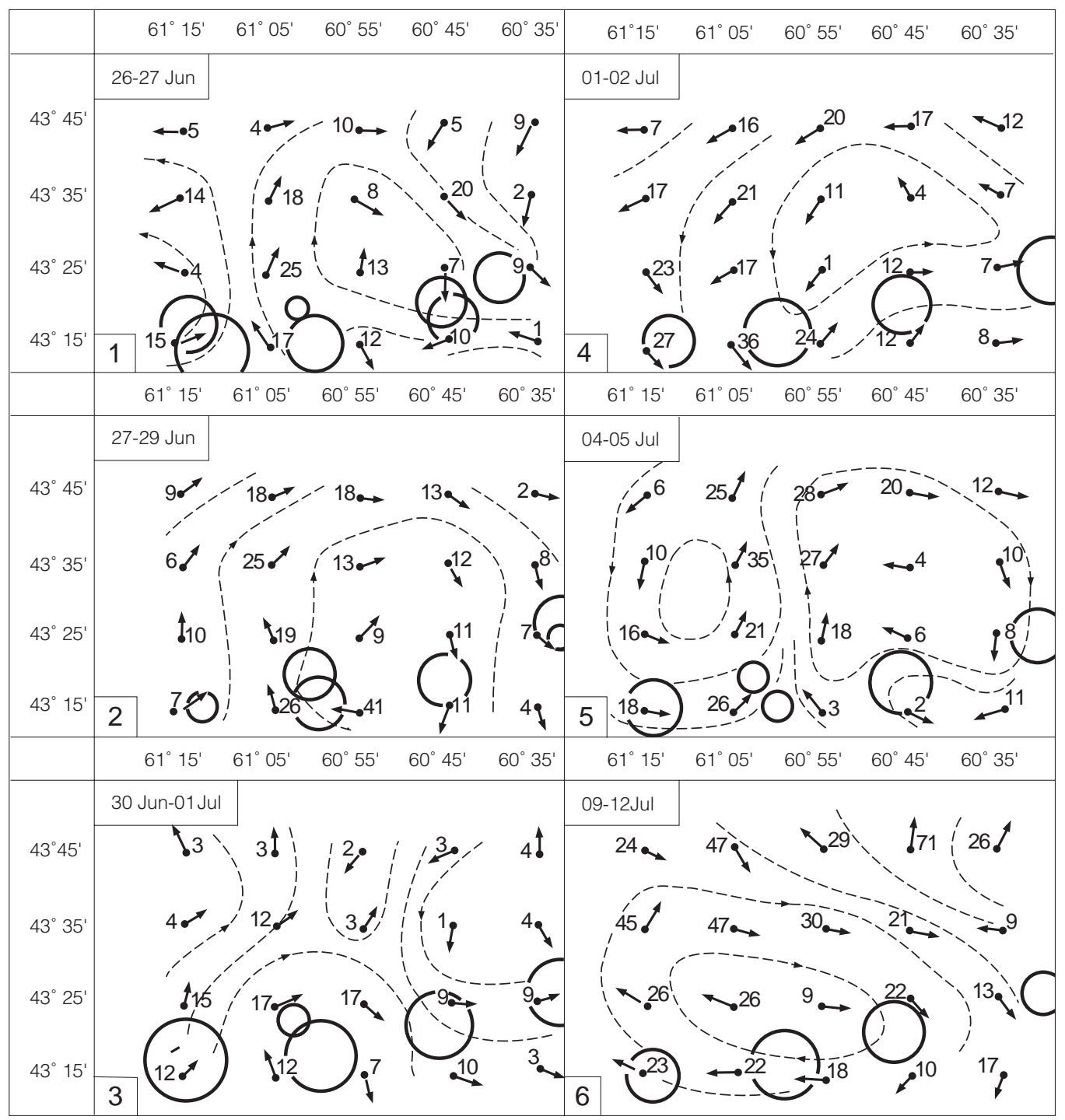

Fig. 9. Mesoscale circulation at the bottom and distribution of silver hake catches within the research survey study area during 1990 (from Sigaev, 1996).

degree of agreement in age interpretation was reached; often over $80 \%$ agreement for the main ages of fish encountered in the fishery. Nonetheless, it was also the case that most exchanges showed biases in the residuals, with Canadian age readings usually tending to be lower than USSR/Russian interpretations but sometimes the reverse (Hunt, 1987a, MS 1991). In general, however, the latest publication on this subject should be noted (Scherbich et al., MS 1992), where an attempt was made to provide more accurate age readings of silver hake up to $25 \mathrm{~cm}$ in length.

Despite the relatively good agreement reached in aging by the working groups, quite large discrepancies occurred between USSR/Russian and Canadian estimates of age compositions of commercial catches. It was then noted that age reading is not the only factor determining estimates of age composition of catches. The length frequency samples used, the way these data are combined and the way age-length keys are applied, were all found to affect the calculation of age composition of catch. Both Hunt (1987b) and Fuong (MS 1990) address this issue. Fuong (MS 1990) points out that, although differences in estimated age compositions of catch were large in the 1970s, these differences became much less after 1977.

Despite the differences in estimates of age composition of silver hake catches produced by various scientists over the years, it is our opinion that the 


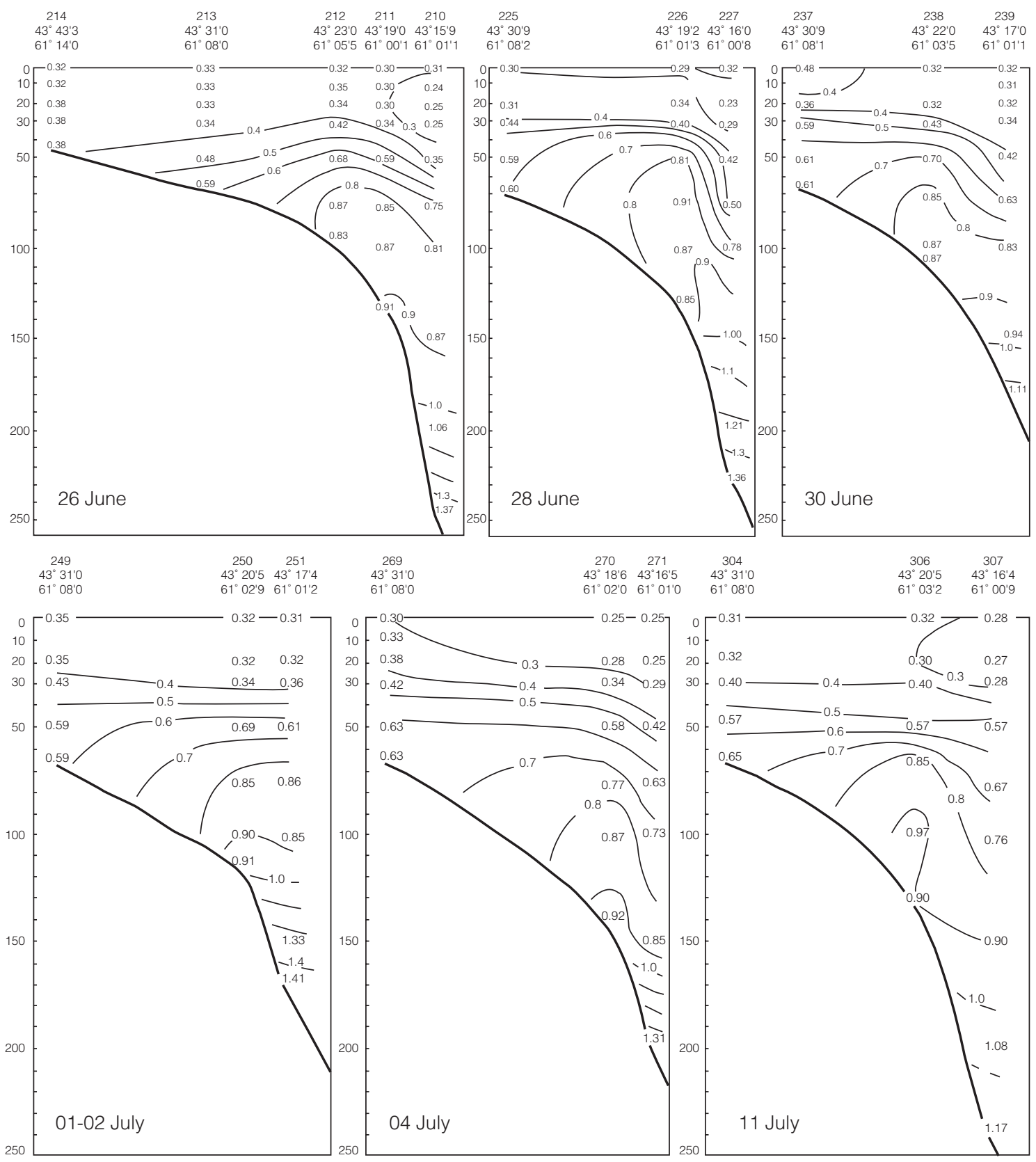

Fig. 10. Upwelling events at the shelf slope as illustrated by phosphates distribution at a single location in one transect of six AtlantNIRO research surveys during 26 June-11 July 1990 (from Sigaev, 1996).

USSR/Russian data in Table 5 provide a satisfactory basis for a general description of the age composition of catches in the 1968-93 period. This may be justified in that silver hake of ages 2-5 years constituted the bulk of USSR/Russian fishery catch sampled during the entire period of observation. Individuals older than 7 years were only found in small numbers or were totally absent. The oldest individuals (12 years old) were caught in 1973. Nevertheless, it should be noted that when fish of extreme older ages are considered, the possibility of misinterpretation of age should not be excluded.

Variations in average age of silver hake in commercial samples may be to a large extent caused by recruitment fluctuations. On the whole, the variation characteristics of the silver hake age composition within the period under discussion 


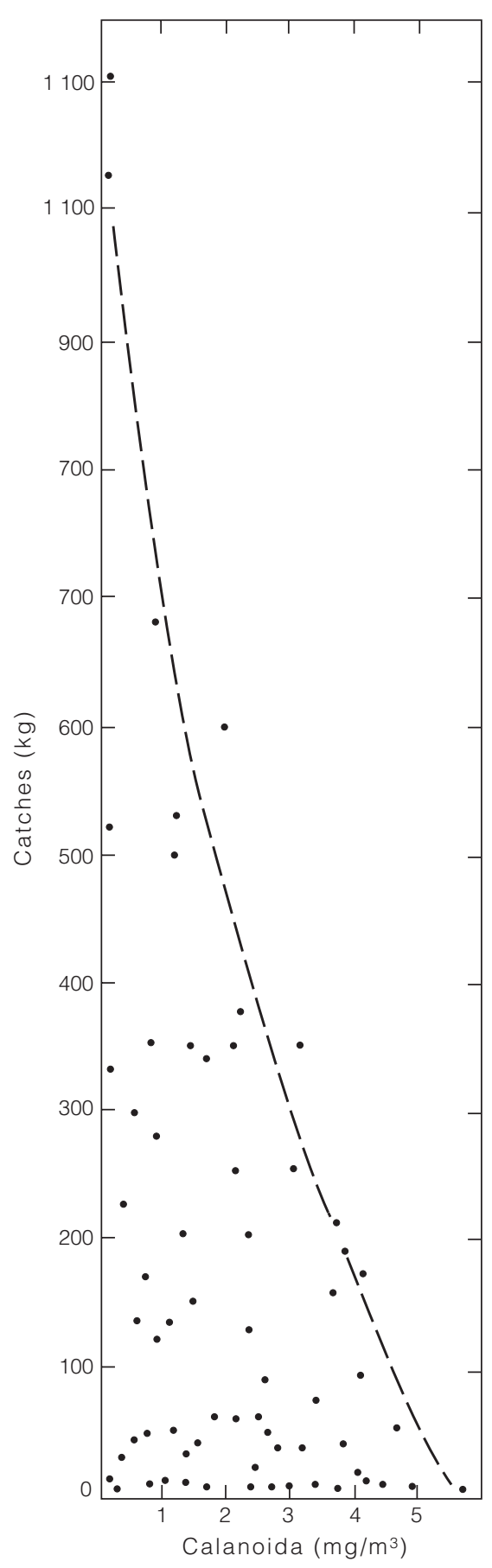

Fig. 11. Correlation between silver hake catches and small zooplankton Calanoida observed during AtlantNIRO research surveys on the Scotian Shelf during 20-31 May 1990 and 7-17 July 1990 (from Sigaev, 1995).

differed little from those of the indices of the length composition. This was also true for the earlier years of silver hake fishery (Noskov, MS 1976).

\section{Growth in length and weight}

The first reported results on growth of silver hake appeared in 1973 (Halliday, MS 1973). The author estimated the mean length by age and parameters of the Von Bertalanffy growth equation using the data on silver hake age readings by USSR scientists (sampling was carried out from commercial catches in 1962-71). Later, a series of similar work appeared covering the period from 1978 to 1990 (Hunt 1978, 1980; Mari, MS 1980; Mari and Valdes, MS 1981; Tizol and Garcia, MS 1988; Fuong, MS 1989, MS 1990).

The main results of this research are summarized in Tables 6, 7, 8. In our opinion the most relevant are those that summarized data of several years; for example there are estimates for 1962-71 and 198185 (both based on the age readings obtained by AtlantNIRO scientists). Comparison of mean lengths by age as obtained from different sources (Table 6) shows the serious deviations for fish older than group 1. Thus silver hake growth during the first year of life revealed little variations over the long period of this study. With regard to older individuals, it is evident that rather important deviations have occurred. Variability apparent in the silver hake growth data is likely to be accounted for by both low quality of material available for analysis (for example sampling shortcomings, ageing inconsistencies) and differences in yearclasses growth rate.

The data in Table 7 show the relative rate of silver hake growth. Assuming that all cases excluding 196271 , correspond to a general biological pattern with the highest growth rate observed during the ages preceding sexual maturation, we may make a preliminary conclusion even without data on maturation rate, that silver hake generally attain maturity at the age of 3 years. Concerning the different pattern of growth shown by the 1962-71 data, it seems reasonable to assume that during the initial period of research by scientists of AtlantNIRO, when silver hake age reading methods were in the process of development and learning played an important role, the proportion of errors was rather high.

As is seen from the above discussion on age reading, the main problems had been resolved by the late-1980s, although errors in age readings of older silver hake (6 years old and older) have not been eliminated yet. These, at least partially, may be the 


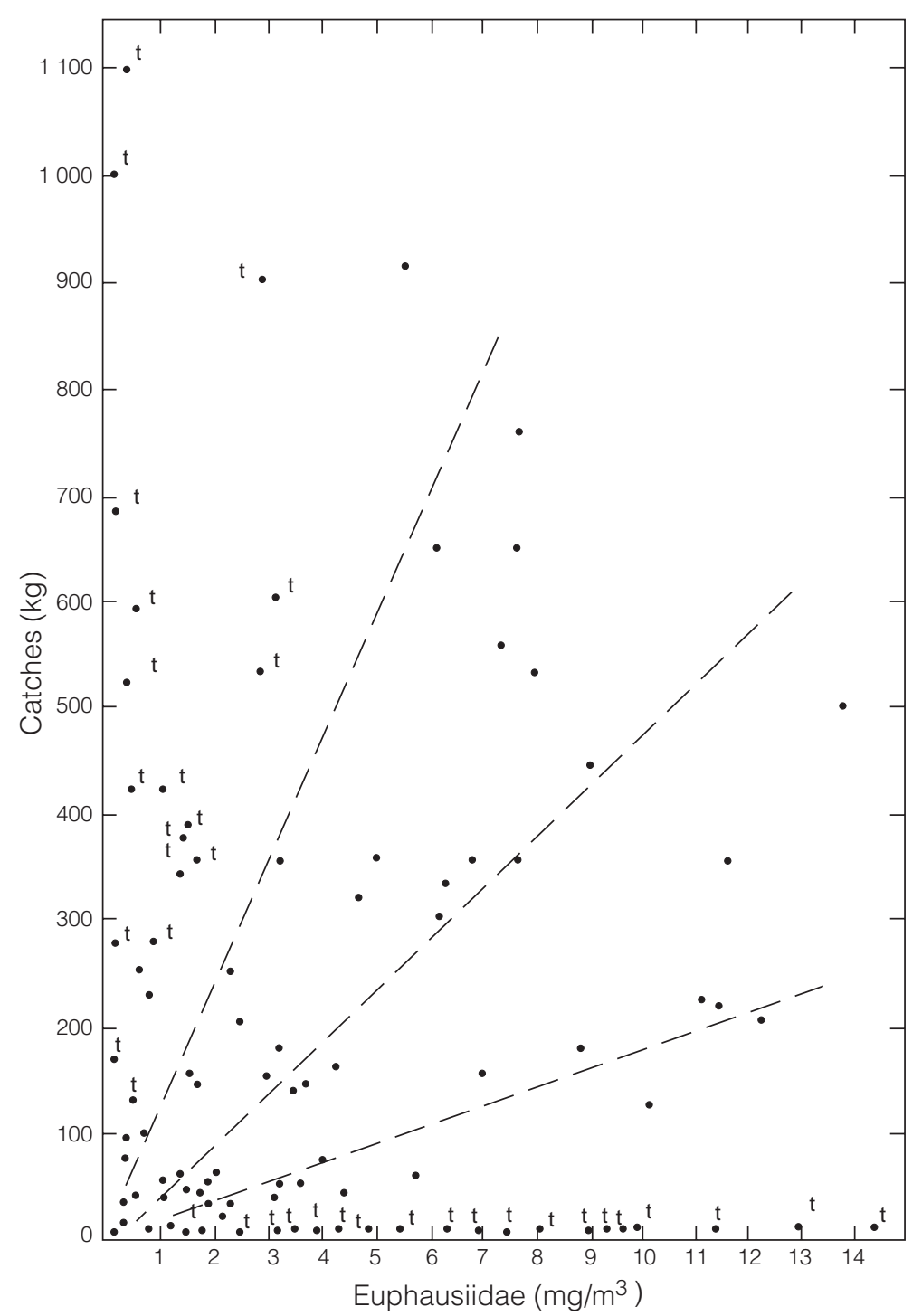

Fig. 12. Correlation between silver hake catches and large zooplankton. Euphausiidae observed during AtlantNIRO research surveys 20-31 May 1990 and 7-17 July 1990 ("t" adjacent to Y axis mean cases with favourable near-bottom water temperature, "t" adjacent to $\mathrm{X}$ axis mean low near-bottom temperature).

reason for high variability of length and weight estimates in the old fish. Fuong (MS 1990), in a comparative analysis of weight growth rate (i.e. mean weight by age), revealed discrepancies in Canadian data (Clay, 1980; Clay and Beanlands, MS 1980) relevant to weight of 7 year old and older fish. The curves describing silver hake growth (data pooled by year) are shown in Fig. 13 and 14 based on Fuong (1980) data. They perhaps provide the most accurate picture of growth as they show the least variability.
Showell (MS 1997) analyzed inter-annual dynamics of silver hake mean weight by age for the period 197096. He showed a trend of sustained decrease of the index considered until 1995.

Parameters of the Von Bertalanffy equation, shown in Table 8 , were also used as a growth rate characteristic. Parameter estimates for males seemed more realistic, which was also noted by Sherstyukov (MS 1990b). In general, judging from the parameter 
TABLE 5. Indices of silver hake length and age composition in 1968-93 in commercial catches of USSR/Russia (unpubl. data by AtlantNIRO).

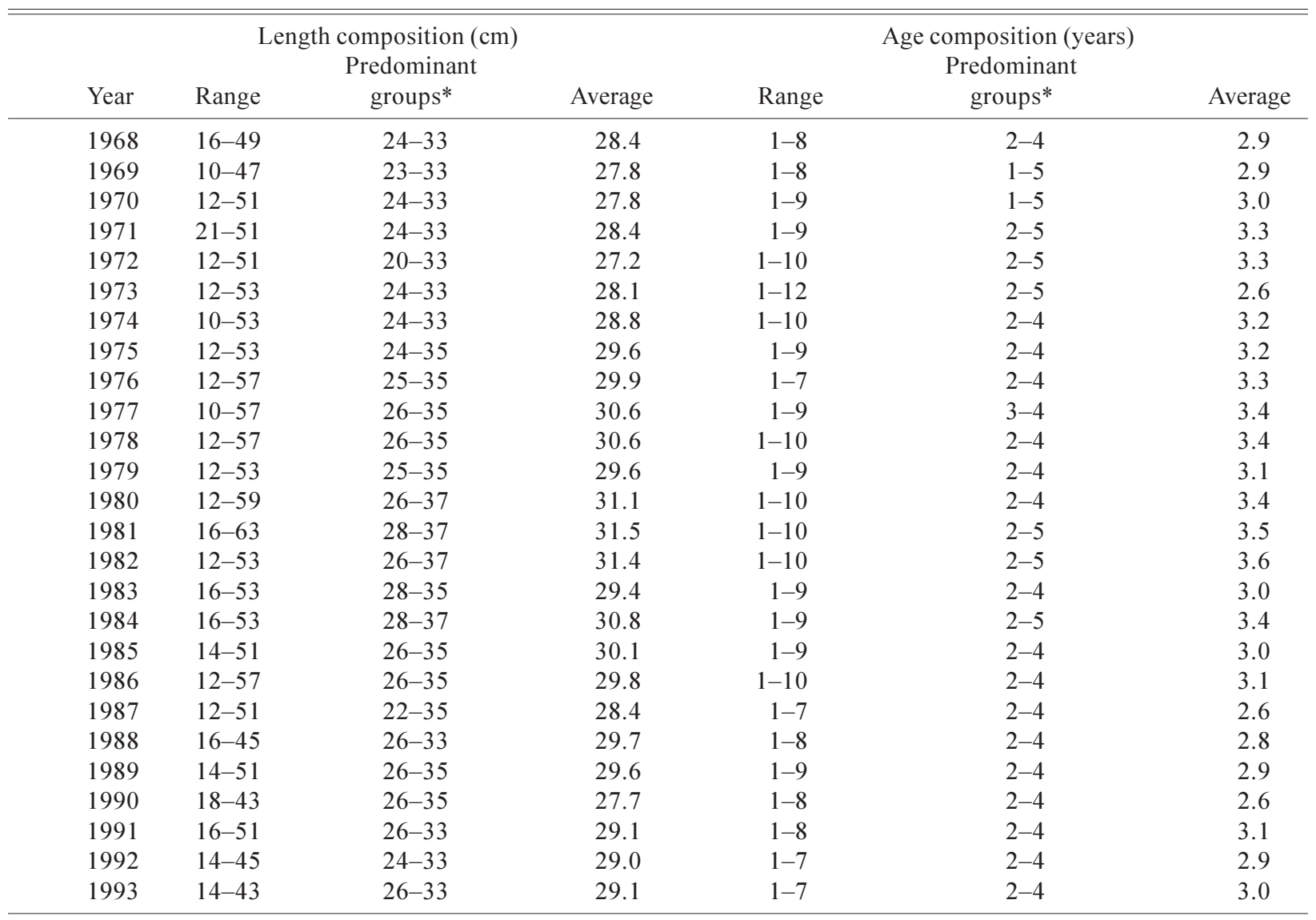

* Length and age groups, which represented more than $80 \%$ by weight in samples (length composition) and in catches (age compositon).

TABLE 6. Average length $(\mathrm{cm})$ and weight $(\mathrm{g})$ of silver hake by age.

\begin{tabular}{|c|c|c|c|c|c|c|c|c|c|c|c|c|}
\hline \multirow{2}{*}{$\begin{array}{l}\text { Period } \\
\text { Year }\end{array}$} & \multirow[b]{2}{*}{ Indices } & \multirow[b]{2}{*}{ Sex } & \multirow[b]{2}{*}{1} & \multirow[b]{2}{*}{2} & \multicolumn{4}{|c|}{ Age (years) } & \multirow[b]{2}{*}{7} & \multirow[b]{2}{*}{8} & \multirow[b]{2}{*}{9} & \multirow[b]{2}{*}{ Source } \\
\hline & & & & & 3 & 4 & 5 & 6 & & & & \\
\hline $1962-71$ & $\begin{array}{l}\text { Average } \\
\text { length }\end{array}$ & MF & 21.3 & 24.3 & 27.9 & 31.03 & 35.0 & 39.6 & 41.8 & 43.2 & 46.2 & Halliday, MS 1973** \\
\hline 1976 & $\begin{array}{l}\text { Average } \\
\text { length }\end{array}$ & $\begin{array}{l}M \\
F\end{array}$ & $\begin{array}{l}20.9 \\
21.1\end{array}$ & $\begin{array}{l}27.9 \\
29.1\end{array}$ & $\begin{array}{l}33.0 \\
34.7\end{array}$ & $\begin{array}{l}34.0 \\
39.9\end{array}$ & $\begin{array}{r}- \\
48.8\end{array}$ & $53 . \overline{0}$ & $56 . \overline{0}$ & - & $56 . \overline{-}$ & Hunt, 1978 \\
\hline $1977-80^{*}$ & $\begin{array}{l}\text { Average } \\
\text { length }\end{array}$ & $\mathrm{M}$ & $\begin{array}{l}17.1- \\
21.9 \\
17.8- \\
22.5\end{array}$ & $\begin{array}{l}25.8- \\
28.7 \\
27.4- \\
29.3\end{array}$ & $\begin{array}{l}31.2- \\
33.7 \\
33.6- \\
36.8\end{array}$ & $\begin{array}{l}24.8- \\
35.5 \\
37.1- \\
42.1\end{array}$ & $\begin{array}{l}36.7- \\
40.0 \\
40.5- \\
48.2\end{array}$ & $\begin{array}{l}- \\
43.9- \\
52.1\end{array}$ & $\begin{array}{l}45.9 \\
54.8\end{array}$ & $\begin{array}{l}54.9 \\
61.5\end{array}$ & $\begin{array}{l}- \\
55.9- \\
66.5\end{array}$ & $\begin{array}{l}\text { Mari, 1980; } \\
\text { Mari and Valdes, } 1981\end{array}$ \\
\hline 1986 & $\begin{array}{l}\text { Average } \\
\text { length }\end{array}$ & $\begin{array}{l}\mathrm{M} \\
\mathrm{F}\end{array}$ & $\begin{array}{l}21.6 \\
22.1\end{array}$ & $\begin{array}{l}28.6 \\
29.1\end{array}$ & $\begin{array}{l}33.5 \\
34.4\end{array}$ & $\begin{array}{l}34.7 \\
38.9\end{array}$ & $44 . \overline{5}$ & $\begin{array}{l}- \\
-\end{array}$ & $\begin{array}{l}- \\
-\end{array}$ & - & - & Tizol and Garcia, 1988 \\
\hline $1981-85$ & $\begin{array}{l}\text { Average } \\
\text { length }\end{array}$ & $\begin{array}{l}\mathrm{M} \\
\mathrm{F} \\
\mathrm{MF}\end{array}$ & $\begin{array}{l}20.3 \\
20.4 \\
20.3\end{array}$ & $\begin{array}{l}26.9 \\
27.0 \\
26.9\end{array}$ & $\begin{array}{l}29.9 \\
30.8 \\
30.2\end{array}$ & $\begin{array}{l}32.2 \\
33.0 \\
32.6\end{array}$ & $\begin{array}{l}34.9 \\
36.4 \\
36.1\end{array}$ & $\begin{array}{l}37.1 \\
39.0 \\
38.9\end{array}$ & $\begin{array}{r}- \\
42.4 \\
42.4\end{array}$ & $\begin{array}{r}- \\
45.9 \\
45.9\end{array}$ & $\begin{array}{r}- \\
50.3 \\
50.3\end{array}$ & Fuong, 1989 \\
\hline $1978-86$ & $\begin{array}{l}\text { Average } \\
\text { weight }\end{array}$ & $\begin{array}{l}\mathrm{M} \\
\mathrm{F} \\
\mathrm{MF}\end{array}$ & $\begin{array}{l}50 \\
47 \\
48\end{array}$ & $\begin{array}{l}112 \\
127 \\
118\end{array}$ & $\begin{array}{l}176 \\
197 \\
185\end{array}$ & $\begin{array}{l}235 \\
264 \\
252\end{array}$ & $\begin{array}{l}292 \\
370 \\
360\end{array}$ & $\begin{array}{l}326 \\
459 \\
446\end{array}$ & $\begin{array}{r}- \\
591 \\
591\end{array}$ & $\begin{array}{r}- \\
803 \\
803\end{array}$ & $\begin{array}{rr} & - \\
1 & 186 \\
1 & 186\end{array}$ & Fuong, 1989 \\
\hline
\end{tabular}

* It is a range of average length for years 1977-80

** The age reading data by USSR scientists were used (sampling from commercial catches in 1962-71). 
TABLE 7. Rate of linear and weight growth of Scotian Shelf silver hake* (\% increase from previous age).

\begin{tabular}{|c|c|c|c|c|c|c|c|c|c|c|c|c|}
\hline \multirow{2}{*}{$\begin{array}{l}\text { Period } \\
\text { Year }\end{array}$} & \multicolumn{12}{|c|}{ Age, years } \\
\hline & Indices & Sex & 1 & 2 & 3 & 4 & 5 & 6 & 7 & 8 & 9 & Source \\
\hline $1962-71$ & $\begin{array}{l}\text { Length } \\
\text { increment }\end{array}$ & MF & & 14.1 & 14.8 & 11.1 & 12.9 & 13.1 & 5.6 & 3.3 & 6.9 & Halliday, MS 1973 \\
\hline \multirow[t]{2}{*}{1976} & Length & M & & 33.5 & 18.3 & 3.0 & - & - & - & - & - & Hunt, 1978 \\
\hline & increment & $\mathrm{F}$ & & 37.9 & 19.2 & 15.0 & 22.3 & 8.6 & - & - & - & \\
\hline \multirow[t]{2}{*}{1986} & Length & M & & 32.4 & 17.1 & 3.6 & - & - & - & - & - & Tizol and \\
\hline & increment & $\mathrm{F}$ & & 31.7 & 18.2 & 13.1 & 14.4 & - & - & - & - & Garcia, 1988 \\
\hline \multirow[t]{3}{*}{$1981-85$} & Length & M & & 2.5 & 11.2 & 7.7 & 8.4 & 6.3 & - & - & - & Fuong, 1989 \\
\hline & increment & $\mathrm{F}$ & & 2.4 & 12.3 & 7.1 & 10.3 & 7.1 & 8.7 & 8.2 & 9.6 & \\
\hline & & MF & & 32.5 & 12.3 & 7.9 & 10.7 & 7.8 & 9.7 & 9.2 & 9.6 & \\
\hline \multirow[t]{3}{*}{$1978-86$} & Weight & M & & 124.0 & 57.1 & 33.5 & 24.2 & 11.3 & - & - & - & Fuong, 1989 \\
\hline & increment & $\mathrm{F}$ & & 170.2 & 55.1 & 34.0 & 40.2 & 24.0 & 28.8 & 35.9 & 47.7 & \\
\hline & & MF & & 145.8 & 56.8 & 36.2 & 42.8 & 23.9 & 28.8 & 35.9 & 47.7 & \\
\hline
\end{tabular}

* Percentage of linear and weight increments was calculated based on the data observed.

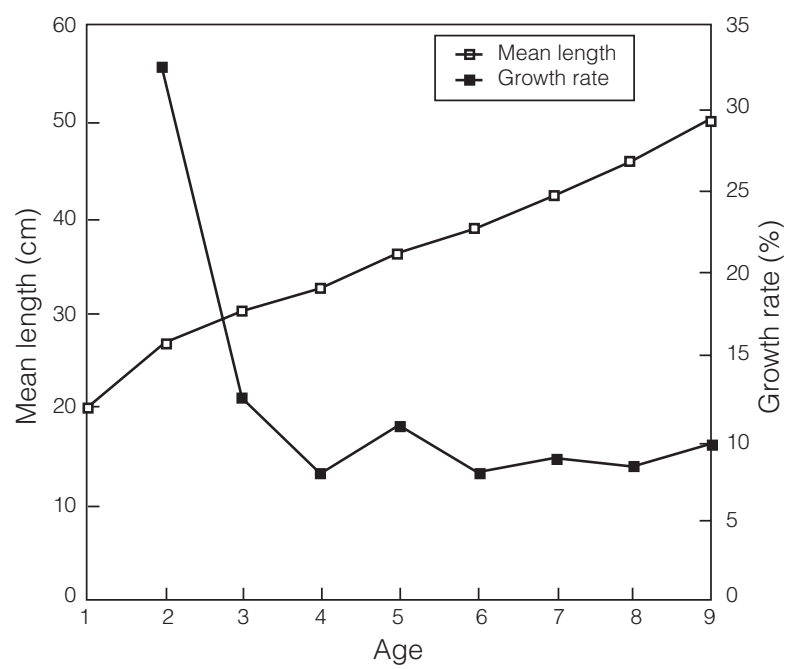

Fig. 13. Average length-at-age and growth rate of Scotian Shelf silver hake based on data of Fuong, 1989.

$\mathrm{K}$ value, which is proportional to the growth rate, silver hake may be referred to as a relatively fast growing species.

The results of recent studies on young silver hake growth should also be mentioned here. In particular it is noteworthy that scientists of AtlantNIRO recently developed a method of estimating daily growth increments of 0-group fish on the basis of otolith microstructure (Sherstyukov, MS 1990b; Markov and

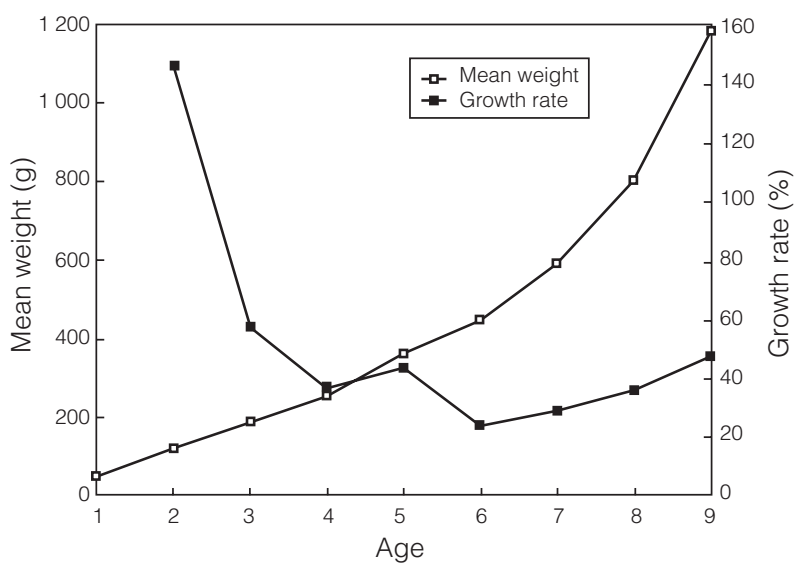

Fig. 14. Average weight-at-age and growth rate of Scotian Shelf silver hake based on data of Fuong, 1989.

Sherstyukov, MS 1991). In these studies, the relationship between age and length of young fish was researched and appropriate equations were obtained (Markov and Sherstyukov, MS 1991).

Many authors have described the pattern of length and weight relationships. However, the most complete information on the relationships was provided by Showell (MS 1997). He estimated a and B coefficients for each year from 1970 to 1996 using the data from Canadian demersal fish surveys carried out in July. He revealed a decreasing trend in silver hake condition 
TABLE 8. Parameters of Von Bertalanfy growth equation for Scotian Shelf silver hake fitted to samples from commercial catches.

\begin{tabular}{|c|c|c|c|c|c|c|}
\hline \multicolumn{7}{|c|}{ Parameters } \\
\hline Indices & Sex & K & $t_{o}$ & $L_{\infty}(\mathrm{cm})$ & $W_{\infty}(g)$ & Source \\
\hline Linear growth & MF & 0.229 & 0.141 & 52.7 & & Halliday, MS 1973 \\
\hline \multirow[t]{2}{*}{ Linear growth } & $\mathrm{M}$ & 0.72 & -0.078 & 36.01 & & Hunt, 1978 \\
\hline & $\mathrm{F}$ & 0.638 & -0.148 & 37.88 & & \\
\hline \multirow[t]{2}{*}{ Linear growth } & $\mathrm{M}$ & 0.412 & -0.192 & 35.08 & & Hunt, 1980 \\
\hline & $\mathrm{F}$ & 0.709 & -0.461 & 43.87 & & \\
\hline \multirow[t]{3}{*}{ Linear growth* } & M & $\begin{array}{l}0.2485- \\
0.5695\end{array}$ & $\begin{array}{l}-1.288- \\
0.1077\end{array}$ & $\begin{array}{l}39.9- \\
47.3\end{array}$ & 436 & $\begin{array}{l}\text { Mari, 1980; } \\
\text { Mari and Valdes, } 1981\end{array}$ \\
\hline & $\mathrm{F}$ & $\begin{array}{c}0.11 .13- \\
0.1563\end{array}$ & $\begin{array}{l}-1.9112- \\
0.9062\end{array}$ & $78.8-86.2$ & & \\
\hline & MF & $\begin{array}{l}0.0912- \\
0.1453\end{array}$ & $\begin{array}{c}-1.9799- \\
0.9505\end{array}$ & $81.3-95.8$ & & \\
\hline \multirow[t]{2}{*}{ Linear growth } & $\mathrm{M}$ & 0.251 & -1.6 & 43.3 & & Fuong, 1989 \\
\hline & $\mathrm{F}$ & 0.054 & -3.1 & 103.3 & & \\
\hline \multirow[t]{2}{*}{ Weight growth } & $\mathrm{M}$ & 0.345 & -0.9 & & 436 & Fuong, 1989 \\
\hline & $\mathrm{F}$ & 0.019 & -3.4 & & 115112 & \\
\hline
\end{tabular}

* Parameters range estimated for each year of the period 1977-80.

(fatness), and hence also a decreasing trend in mean weight by age between 1970 and 1995. It is difficult to specify exact reasons behind this trend.

Fuong (MS 1990) suggested that the lengthweight relationship used by Canadian scientists in some cases could be a reason for the incorrect estimates of the mean weights by age groups. However, it is not clear from his paper whether he meant the relationships constructed using data of Canadian July surveys. In our opinion, the indicated decreasing trend may be partially explained by the fact that Canadian estimates of length-weight relation parameters were based on the data of trawling surveys carried out annually in July. It is known that this month is the beginning of the spawning time of silver hake, which is not fixed and varies between years. It means that the gonad state (e.g. pre-spawning or post-spawning) may significantly impact the weights of fish of similar length. Rikhter and Konovalov (MS 1985) estimated average maturity stages of adults by year and month, and the results favoured the assumption that spawning time has varied among years. Hunt (MS 1995) also assumed such a possibility based the analyses of the proportion of maturity stages present by year during July survey. However, such inter-annual variations do not explain the long-term trend in the fish condition observed by Showell (MS 1997). It seems that research into the problem should be continued.

\section{Sex Maturity and Gonad Development}

In this study we performed an analysis of sexual maturation using the traditional 6-point scale of fish gonad maturity, as modified by Sauskan and Serebryakov (1968), taking in account silver hake batch spawning. In this case we preferred to combine all intermediate female maturity stages into one stage 5 which characterized the spawning process, despite the gonad condition. This method, in our opinion, was reasonable, because it takes into account the problems relevant to intermediate stage specifications and the inevitable errors involved. It provides a clearer, though less detailed, picture of silver hake maturation by month. 
Gonad maturation stages (data averaged for 1972, 1974 and 1976) by month is shown in Table 9. The percentages of stage $\mathrm{V}$ provide evidence that spawning begins in June (apparently by the end of the month), approaches a peak in July-August and finishes in September. This is interpreted by the sharp increase of fish at stage II during September-October. It is noted that while before-spawning stage II includes only juvenile fishes, in the autumn this stage may be easily confused with stage VI-VII, which indicate gonad recovery after spawning and transfer to a new reproduction cycle. We have no data for NovemberFebruary at our disposal, however, this is not so important, since on the basis of information presented we may easily conclude that during the autumn period adult gonads are at stage III.

To analyze sexual maturation rate by age, only samples obtained in May and June by Russian observers on commercial vessels were used, since in those months immature individuals and those that will spawn during the current year may be separated without error. Again the data used were from 1972, 1974 and 1976. The actual age readings made by AtlantNIRO scientists for these years were used. The accuracy of age estimates was not sufficiently high during that study period. Therefore, the data presented (Table 10) provide only general conclusions that; mature individuals (mainly males) were observed for the first time at the age of 1 year, among 2-year-old fish the proportion of mature fish exceeded $50 \%$, while at the age of 3 years all fish were sexually mature. Similar analyses on the first two age groups were carried out by Canadian scientists for 1971-74 (Doubleday and Halliday, 1976) and showed similar results.

A clear picture on silver hake sexual maturity by length is provided by Doubleday and Halliday (1976). Based on information summarized for 1971-75 (Fig.15), it may be concluded that males reach about $50 \%$ maturity at length of $24 \mathrm{~cm}$ while females at the length of $27 \mathrm{~cm}$. Ogive based on data from Doubleday and Halliday (1976) was fitted by authors of this paper.

TABLE 9. Average silver hake gonad development (\% maturity stages)* by months for 1972, 1974 and 1970 (samples from commercial catches of USSR, unpubl. data aby AtlantNIRO). $(\mathrm{M}=$ males; $\mathrm{F}=$ females $)$.

\begin{tabular}{|c|c|c|c|c|c|c|c|c|c|c|c|c|c|c|c|c|}
\hline \multirow{3}{*}{$\begin{array}{l}\text { Maturity } \\
\text { Stages }\end{array}$} & \multirow{2}{*}{\multicolumn{2}{|c|}{ March }} & \multirow{2}{*}{\multicolumn{2}{|c|}{ April }} & \multirow{2}{*}{\multicolumn{2}{|c|}{ May }} & \multicolumn{4}{|c|}{ Months } & \multirow{2}{*}{\multicolumn{2}{|c|}{ August }} & \multirow{2}{*}{\multicolumn{2}{|c|}{ September }} & & \\
\hline & & & & & & & & ine & & July & & & & & \multicolumn{2}{|c|}{ October } \\
\hline & $\mathrm{M}$ & $\mathrm{F}$ & $\mathrm{M}$ & $\mathrm{F}$ & $\mathrm{M}$ & $\mathrm{F}$ & $\mathrm{M}$ & $\mathrm{F}$ & $\mathrm{M}$ & $F$ & $\mathrm{M}$ & $\mathrm{F}$ & $\mathrm{M}$ & $\mathrm{F}$ & $\mathrm{M}$ & $\mathrm{F}$ \\
\hline II & 37.1 & 48.9 & 25.0 & 35.1 & 8.9 & 20.8 & 4.8 & 6.5 & 9.5 & 11.9 & 17.6 & 29.8 & 33.5 & 41.8 & 61.3 & 54.9 \\
\hline III & 53.2 & 46.3 & 56.1 & 57.7 & 53.4 & 32.2 & 18.1 & 25.7 & 24.7 & 16.8 & 24.7 & 31.2 & 27.3 & 32.4 & 16.2 & 10.0 \\
\hline IV & 4.1 & 1.9 & 18.8 & 6.0 & 35.8 & 44.7 & 65.2 & 50.2 & 35.7 & 42.6 & 35.5 & 13.9 & 20.9 & 7.8 & 1.9 & 0.3 \\
\hline V & - & - & - & - & 1.8 & .2 .2 & 11.9 & 17.6 & 19.5 & 26.6 & 19.4 & 23.0 & 13.8 & 12.3 & 1.0 & 4.9 \\
\hline VI & - & - & - & - & - & - & - & - & 10.6 & 0.4 & 2.8 & 1.2 & 1.9 & 0.7 & 9.6 & 1.3 \\
\hline VI-II & 5.6 & 2.9 & 0.1 & 1.2 & 0.1 & 0.1 & - & - & - & 1.7 & - & 0.9 & 2.6 & 5.0 & 10.0 & 28.6 \\
\hline Total & 100.0 & 100.0 & 100.0 & 100.0 & 100.0 & 100.0 & 100.0 & 100.0 & 100.0 & 100.0 & 100.0 & 100.0 & 100.0 & 100.0 & 100.0 & 100.0 \\
\hline
\end{tabular}

* Proportion of silver hake gonads at different development stages

TABLE 10. Scotian Shelf silver hake percent mature by age based on commercial fishery samples collected in May-June and averaged for years 1972, 1974 and 1976.

\begin{tabular}{cccccc}
\hline \hline & \multicolumn{2}{c}{ Males } & & \multicolumn{2}{c}{ Females } \\
\cline { 2 - 3 } \cline { 5 - 6 } Age, years & $\begin{array}{c}\text { No. of } \\
\text { individuals }\end{array}$ & $\begin{array}{c}\text { \% of mature } \\
\text { individuals }\end{array}$ & & $\begin{array}{c}\text { No. of } \\
\text { individuals }\end{array}$ & $\begin{array}{c}\text { \% of mature } \\
\text { individuals }\end{array}$ \\
\hline 1 & 211 & 21.3 & & 204 & 1.0 \\
2 & 229 & 78.6 & & 267 & 62.2 \\
3 & 234 & 95.3 & & 261 & 91.9 \\
4 & 122 & 97.5 & & 132 & 96.9 \\
5 & 29 & 100.0 & & 103 & 100.0 \\
\hline
\end{tabular}




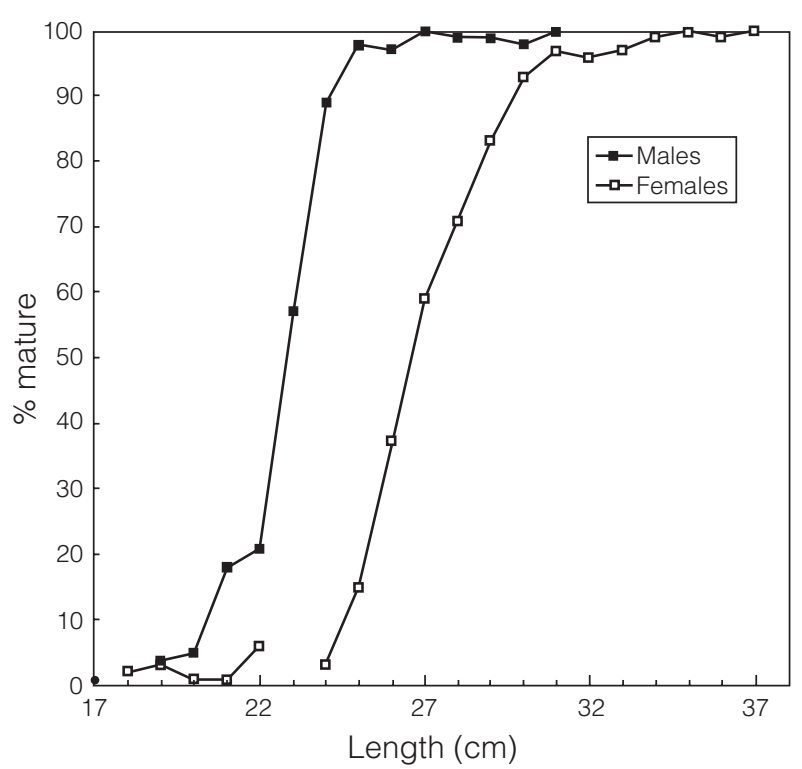

Fig. 15. Length and maturation rate of Scotian Shelf silver hake by sexes (from Doubleday and Halliday, 1976).

The within-year spawning period is not fixed and the months may vary over a certain range between years. We propose the fluctuations are caused by variations in gonad maturation rate as linked to environmental factors. To reveal the above variations in silver hake, average maturity stage was estimated for June (a month preceding peak spawning). The data for 1977-93 were used when sampling during June was carried out without break and approximately in similar volume, while maturity stages were assessed strictly according to the manual developed in AtlantNIRO. Stage II, which describes individuals to be spawning in the next year, was excluded from calculations.

Silver hake maturation rate during this period varied within a large range (Fig. 16), and it may be assumed this would affect the time of spawning migrations. Results of research carried out by Rikhter and Konovalov (MS 1985) confirm, to a certain extent, this assumption. The most typical picture was observed in 1983 (Rikhter and Konovalov, MS 1985), when there was mass movement of silver hake from the continental slope towards shallow areas where major spawning occurred in June. According to the data by Rikhter and Turok (1984) this event most likely occurred in the last ten days of the month. Usually such migrations were observed in JulyAugust. Certainly, hydrological conditions may also

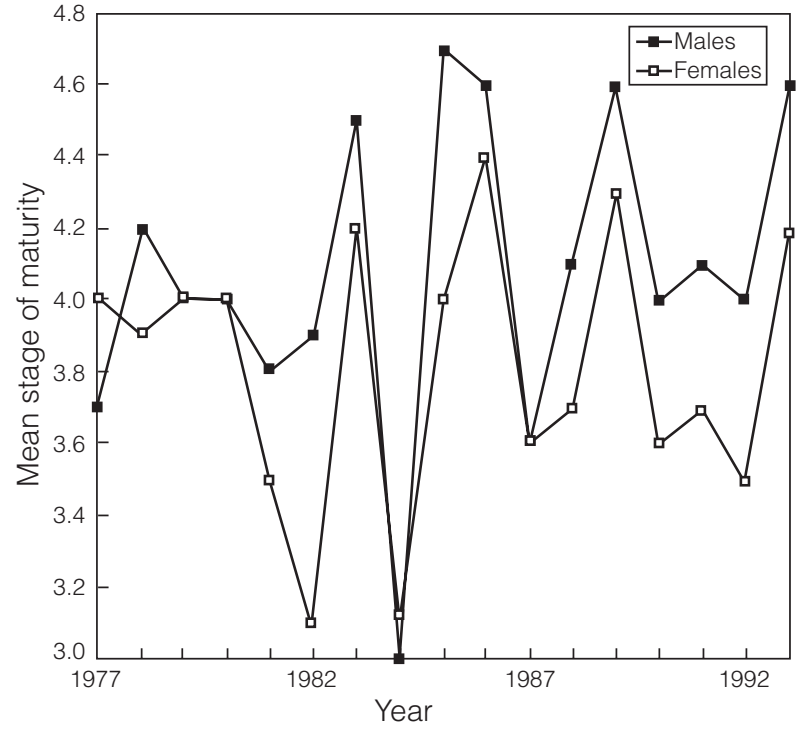

Fig. 16. Dynamics of average stages of Scotian Shelf silver hake maturity in June by years and sexes.

affect the time of these migrations as discussed previously. Concerning probable reasons of maturation rate fluctuations annually, food availability, which may be directly related to the population abundance, also may play an important role in addition to oceanographic factors (primarily thermal regime).

Evidently, maturation rate variations are directly related to silver hake distribution and behaviour, and therefore linked to the availability of silver hake to any fishery in the area southwards of the line limiting the area of small mesh fishing gear use (small mesh gear line, SMGL).

Unfortunately, silver hake fecundity has not been sufficiently researched. The data available (Sauskan and Serebryakov, 1968; Mari and Ramos, 1980) are very scanty and allow only a general observation that a high fecundity is typical of this species similar to other gadoids. In general, the data considered allow us to conclude that silver hake belongs to species with high reproductive potential.

\section{Feeding and Trophic Interrelations}

Scientists of USSR/Russia and Canada have paid considerable attention to research on silver hake feeding in the Scotian Shelf area. The data obtained in these research have been published in several articles during 1982-99. Here we summarize the main results obtained in the period, and silver hake feeding 
peculiarities and trophic relations at different stages of its life cycle are considered.

Larval stage. Study of feeding was started in 1977, when the major food items of pre-larvae (according to classification by Sauskan and Serebryakov, 1968) of 2-9 $\mathrm{mm}$ in length (the beginning of exogenous feeding) were specified by USSR scientists (Noskov et al., 1982) for the period August and September. Those items included representatives of Copepods of 0.7-1.2 mm in length with Clauso-calanus spp., Paracalanus spp. and others (Table 11) predominant in the stomach contents. Silver hake larvae of $9-23 \mathrm{~mm}$ in length (totally exogenous feeding) consumed mainly Calanus finmarchicus of 2-2.5 $\mathrm{mm}$ in length. Sometimes representatives of Centropages spp. (1.2-2 $\mathrm{mm}$ ) constituted an important proportion in those stomach contents. As a rule, in August the number of larvae with full stomachs was higher than in September, while feeding rate (consumption index, \%००) was higher only in the smallest individuals $(2-6 \mathrm{~mm})$. In larger larvae, feeding rate was higher in September when such large organisms as C. finmarchicus, Centropages spp., Oithona spp. were available (Noskov et al., 1982).

Juvenile stage (fry). Increase of average size of food organisms as well as increase of the total food weight, the bulk of which consisted of euphausiids, amphipods, hyperiids and decapods, was observed in silver hake fry of $30 \mathrm{~mm}$ in length in October-
December (Noskov et al., MS 1982). Fifty percent of food items in fry of $30-40 \mathrm{~mm}$ in length was represented by euphausiids and hyperiids, while in fry of 70-80 mm, up to $100 \%$ of food weight was made up of euphausiids (Table 12). According to the data by Koeller et al. (1989) in October 1980 stomachs of fry of 30-50 $\mathrm{mm}$ in length were filled with Parathemisto gaudichaudii (50\% of occurrence). In October 1981 fry of the same length consumed mainly copepods (C. finmarchicus, Centropages typicus). Parathemisto gaudichaudii and Meganyctiphanes norvegica were found in the stomachs of larger fry (50-80 $\mathrm{mm})$. In January 1981 the same authors observed $M$. norvegica as the major food item of silver hake fry of 50-80 $\mathrm{mm}$ in length. Sherstyukov and Nazarova (MS 1987) found that in November 1985 only in the smallest fry $(20-40 \mathrm{~mm})$ found in the stratified layer, copepods and euphausiids constituted $35-59 \%$ and $40-65 \%$ of food by weight, respectively. In larger fry $(50-110 \mathrm{~mm}) M$. norvegica constituted $66-100 \%$ by weight both in homogeneous and stratified layers of water. However, long-term observations (Vinogradov, MS 2000) showed that in some years (October 1982) copepods predominated in food of fry (56-85 mm) (Table 13) and even adult fish. In October-November 1983 and 1984, decapods and small silver hake (cannibalism) constituted the bulk of fry food. Similar results were obtained by Clay et al. (MS 1984).

Apparently in some seasons of the observed period young silver hake of specified length consumed,

TABLE 11. Food composition for larval silver hake of different length ( $\mathrm{mm}$ ) sampled for commercial vessels during August, September 1974, 1977-80, given as \% by weight (from Noskov et al., MS 1982).

\begin{tabular}{|c|c|c|c|c|c|c|c|c|c|c|c|c|}
\hline \multirow[b]{2}{*}{ Food organisms } & \multicolumn{2}{|c|}{$2.0-5.9$} & \multicolumn{2}{|c|}{$6.0-8.9$} & \multicolumn{2}{|c|}{$9.0-12.9$} & \multicolumn{2}{|c|}{$13.0-17.9$} & \multicolumn{2}{|c|}{$18.0-22.9$} & \multicolumn{2}{|c|}{$2.0-22.9$} \\
\hline & VIII & IX & VIII & IX & VIII & IX & VIII & IX & VIII & IX & VIII & IX \\
\hline Ova copepoda & 1 & 1 & 1 & + & + & + & - & + & - & + & 1 & + \\
\hline Nauplii copepoda & 6 & 7 & 1 & 1 & - & + & - & - & - & - & 1 & 2 \\
\hline Calanus finmarchicus & - & - & 7 & 13 & 43 & 51 & 22 & 31 & - & 47 & 14 & 28 \\
\hline Paracalanus sp. & 7 & 23 & 15 & 18 & 9 & 3 & - & 3 & - & 4 & 6 & 10 \\
\hline Pseudocalanus spp. & 10 & 5 & 9 & 8 & - & 1 & - & 1 & - & 1 & 4 & 3 \\
\hline Clausocalanus spp. & 27 & 20 & 12 & 17 & 6 & 2 & 1 & 1 & - & 3 & 9 & 9 \\
\hline Aetidius spp. & - & - & - & + & - & 1 & - & 4 & - & 3 & - & 2 \\
\hline Centropages spp. & 1 & 2 & 4 & 8 & 14 & 22 & 10 & 23 & 100 & 18 & 26 & 15 \\
\hline Candacia spp. & - & - & - & + & - & + & - & 1 & - & 1 & - & 1 \\
\hline Oithona spp. & 5 & 8 & 3 & 4 & 1 & + & - & + & - & + & 2 & 2 \\
\hline $\begin{array}{l}\text { Nonidentified } \\
\text { and digested Copepoda }\end{array}$ & 43 & 34 & 48 & 31 & 27 & 20 & 3 & 35 & - & 13 & 24 & 26 \\
\hline Euphausiacea & - & - & - & - & - & - & 40 & 1 & - & 10 & 8 & 2 \\
\hline Decapoda larvae & - & - & - & - & - & - & 24 & - & - & - & 5 & - \\
\hline Total & 100 & 100 & 100 & 100 & 100 & 100 & 100 & 100 & 100 & 100 & 100 & 100 \\
\hline
\end{tabular}


TABLE 12. Food composition for silver hake fry of different length (mm) sampled from commercial vessels during October 1979-80, given as \% by weight (from Noskov et al., MS 1982).

\begin{tabular}{|c|c|c|c|c|c|c|c|}
\hline \multirow[b]{2}{*}{ Food organisms } & \multicolumn{7}{|c|}{ Fry length group } \\
\hline & $30.0-39.9$ & $40.0-49.9$ & $50.0-59.9$ & $60.0-69.9$ & $70.0-79.9$ & $80.0-89.9$ & $30.0-89.0$ \\
\hline Calanus finmarchicus & + & - & + & - & - & - & + \\
\hline Undinula spp. & 1 & + & + & - & - & - & + \\
\hline Paracalanus spp. & 8 & + & - & - & - & - & 4 \\
\hline Pseudocalanus spp. & + & 2 & - & - & - & - & + \\
\hline Clausocalanus spp. & - & - & 4 & - & - & - & + \\
\hline Metridia spp. & 4 & 8 & + & - & - & - & 4 \\
\hline Aetidius spp. & - & + & - & - & - & - & + \\
\hline Centropages spp. & 21 & 8 & 4 & + & - & - & 8 \\
\hline Candacia spp. & 1 & 6 & + & - & - & 12 & 4 \\
\hline Temora spp. & - & + & - & - & - & - & + \\
\hline Scolecithfix spp. & + & 10 & - & - & - & - & 3 \\
\hline \multicolumn{8}{|c|}{ Nonidentified and digested Copepoda } \\
\hline Mysidacea & 1 & 1 & 1 & - & - & - & 1 \\
\hline Cumacea & + & + & - & - & - & & + \\
\hline Gammarida & 1 & 1 & 8 & - & - & - & 3 \\
\hline Hyperiidae & + & - & - & - & - & - & + \\
\hline Amphipoda & 9 & 5 & 3 & 1 & - & - & 4 \\
\hline Euphausiidae & 16 & 15 & 25 & 48 & 100 & - & 20 \\
\hline Parathemisto spp. & 30 & 30 & 41 & 35 & - & 31 & 35 \\
\hline Decapoda zoea & + & + & 2 & 1 & - & - & 1 \\
\hline Polychaeta & 1 & 6 & 10 & 15 & - & - & 8 \\
\hline Nemertini & + & 2 & - & - & - & - & + \\
\hline Sagitta spp. & + & + & + & - & - & 57 & + \\
\hline Bivalvia & + & + & - & - & - & - & + \\
\hline Larval fish & 3 & 5 & 3 & - & - & - & 4 \\
\hline Larval hake & 4 & - & - & - & - & - & 1 \\
\hline Total & 100 & 100 & 100 & 100 & 100 & 100 & 100 \\
\hline
\end{tabular}

amphipods, hyperiids and copepods of more suitable size in the absence of euphausiids of appropriate length. Sometimes this list was supplemented with Pteropoda, shown in the Table 13 as "miscellaneous" and small silver hake (cannibalism), but seldom exceeded $20 \%$ of the stomach content by weight. Sometimes, in the larger stomachs, silver hake individuals were found approaching $90 \%$ of the predator's length; however in general, they did not exceed $25 \%$ of the length.

Long-term research carried out by USSR/Russia showed that more intensive food consumption (up to $40 \%$ by weight) occurred in young fish (26-45 mm) in October-November but sharply decreased in larger individuals. In December-January food consumption was similar to that in October-November while consumption indices of the largest individuals (106-
$115 \mathrm{~mm}$ ) were approximately similar during all periods and exceeded $1000 \%$ (Vinogradov, 2000) where consumption index is the estimated live weight of prey, using tables of weights of North Atlantic and Mediterranean zooplankters, divided by fish weight and multiplied by 10000 to obtain convenient integers.

The decade of observations of young silver hake feeding rate by length groups in October revealed the lowest food consumption in 1984 and 1985 (from 200 to $1100 \%$, while in other years $(1982,1983$ and 1986-90) consumption indices varied from 1100 to $5700 \%$ (Table 13). As a rule, the highest indices were observed in small fry $(26-45 \mathrm{~mm})$.

A low index of $20 \%$ was obtained for November 1986 (Table 13) for silver hake of 86-115 mm length. 

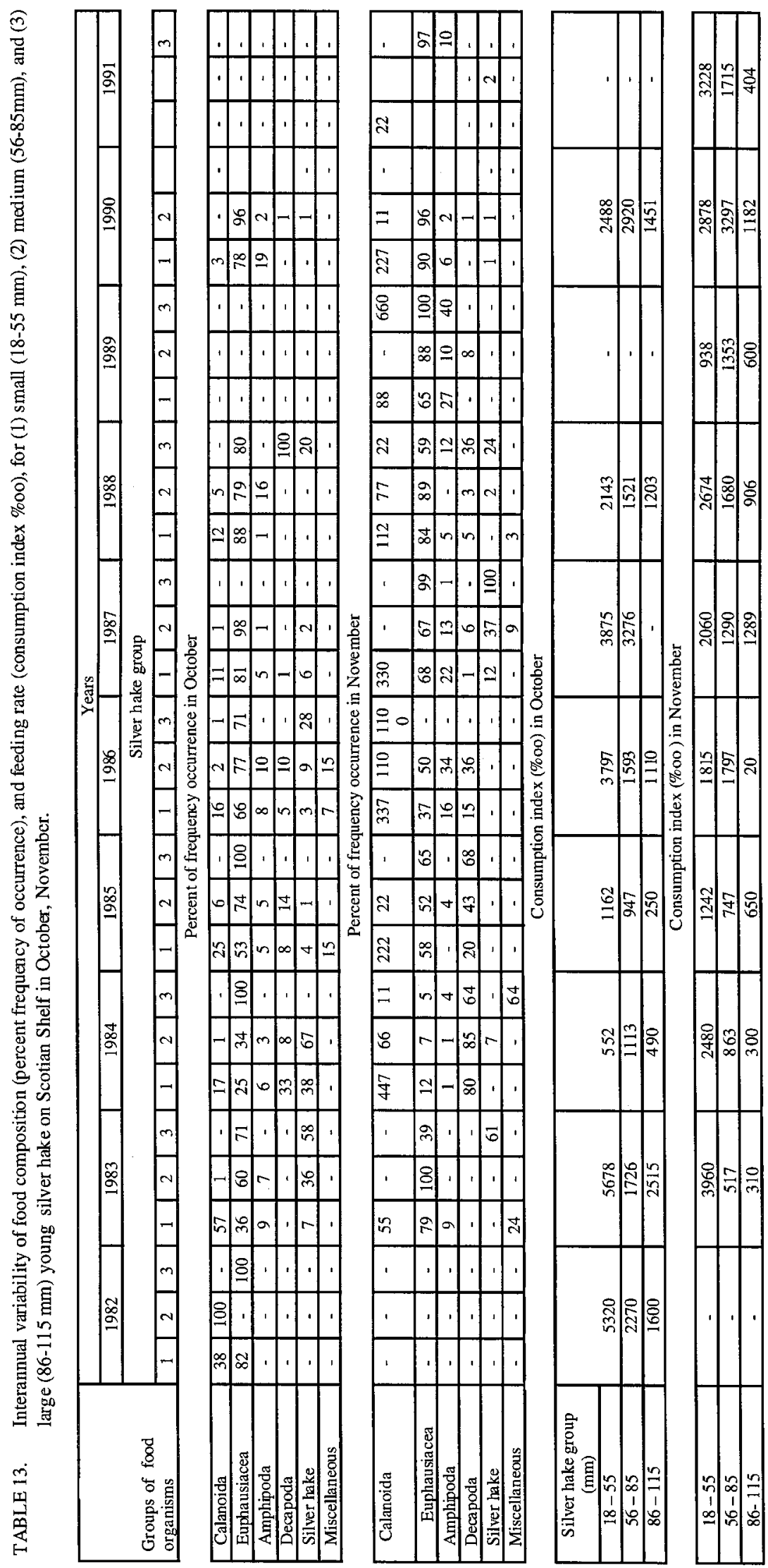
Consumption indices for smaller individuals (26-85 $\mathrm{mm}$ ) varied from 500 to $4000 \%$.

Adult stage (1 year old and older). Temperature gradients formed during spring-summer periods in the near-bottom layer of the Scotian Shelf in the area of silver hake spawning grounds at Emerald Bank and Sable Island Shoal, as a rule, create forage conditions favourable to good feeding and formation of dense commercial aggregations (Vinogradov, 1988). Thus, during the years of high uniform temperatures over the entire shelf when the feeding conditions became unfavourable, silver hake dispersed searching for food and no dense aggregations were observed during the pre-spawning period.

Numerous plankton organisms undertake diurnal vertical migrations. Being food items of silver hake, particularly of young silver hake, the silver hake follow them. This pattern was confirmed with increases in pelagic silver hake catches during zooplankton (especially, euphausiids) ascent at night (1600-2400 hr) and descent in the morning (0400$0800 \mathrm{hr}$ ) (Sherstyukov and Vinogradov, MS 1991; Vinogradov, MS 1993). Studies of vertical migrations of silver hake, based on bottom and pelagic trawls, show that fish ascent began at noon and finished by $2000 \mathrm{hr}$. The most active feeding mainly upon $M$. norvegica occurred from $2000 \mathrm{hr}$ to $0800 \mathrm{hr}$. Selectivity of silver hake feeding has also been found, particularly the larger euphausiids were found to be the preferred food item (Sherstyukov and Vinogradov, MS 1991; Vinogradov, MS 1993).

Silver hake feeding rate increased in the years when its food consisted mainly of abundant organisms (Vinogradov, MS 1993). Often the feeding rate changed synchronously in males and females and coincided with the seasonal periods specified by Karasiev (1975) as "over-wintering" (NovemberApril), "feeding" (April-June), "spawning" (JulyOctober). Similarly, Waldron (1992) found differences by age in silver hake feeding during spring, summer and autumn periods.

To research feeding, Vinogradov, (MS 1993) sampled stomachs of silver hake in the following length groups: 12-25 cm (mainly juvenile); 26-35 $\mathrm{cm}$ (mature, generally spawning fish); $36-58 \mathrm{~cm}$ (the older age groups with high natural mortality, mainly females). The results of juvenile males and females (12-25 cm) feeding during 24-hours in summer revealed that the feeding rhythm and rates were similar by sex, and migrating copepods and euphausiids were the major food items. Adult males (26-32 cm) fed only upon euphausiids of 30-35 mm in length with peaks in feeding intensity at $1500 \mathrm{hr}$ and especially at $2300 \mathrm{hr}$. A similar rhythm of feeding upon euphausiids was found in females of $26-35 \mathrm{~cm}$ in length, but euphausiids was the main food overall. Large females $(36-52 \mathrm{~cm})$ consumed small silver hake (cannibalism) as well as other species of fish and squid of appropriate small sizes. Euphausiids still made up part of the intake. The bulk of the stomach content of large females consisted of young silver hake, and more rarely of mackerel and white and red hake (Table 14). In general, the results obtained are comparable to those of Waldron (1992). Diurnal rhythm of food consumption, especially that of large food items, was hardly noticeable in females.

Cannibalism was a characteristic feature of large silver hake feeding. It may be suggested that feeding upon the young representatives of the same species plays some role in abundance recruitment formation of species under consideration. Therefore, changes of cannibalism rate by year may be used as an indirect indication of year-class abundance of recruits entering the fishery.

Daily rations of silver hake, estimated for females and males of 12-35 cm in length in June varied within $12.8-18 \%$ of body weight for males and $11.7-26.9 \%$ for females. In July the estimates were 3.8-6.9\% for males and $6.3-9.0 \%$ for females. Daily rations of large females in June-July varied within $22.5-31.2 \%$.

\section{Probable Role of Silver Hake in the Scotian Shelf Ecosystem}

Taking into account that silver hake has been one of the most abundant fish species (if not the most abundant) in the Scotian shelf area, we may suppose that its impact upon the other species abundance in the ecosystem of the area is rather significant. In this connection, silver hake interrelations with species such as cod, pollock and haddock are most interesting. Distribution areas of all above-mentioned species more or less overlap, therefore competition for food and consumption of smaller fish by large specimens of similar species may occur. Data from appropriate research were obtained; for silver hake from Showell (MS 1996), cod from Fanning et al. (MS 1996), haddock from Zwanenburg et al. (MS 1995) and pollock from Neilson and Perley (MS 1995). A general idea on possible silver hake impact upon cod, haddock 
TABLE 14. Food composition (\% by weight) for adult silver hake on Scotian Shelf of different length groups in 1990 (from Vinogradov, MS 1993b).

\begin{tabular}{|c|c|c|c|c|c|c|}
\hline \multirow[b]{2}{*}{ Food items } & \multicolumn{2}{|c|}{ Small $(12-25 \mathrm{~cm})$} & \multicolumn{2}{|c|}{ Medium $(26-35 \mathrm{~cm})$} & \multicolumn{2}{|c|}{ Large $(36-58 \mathrm{~cm})$} \\
\hline & Males & Females & Males & Females & Males* & Females \\
\hline Gyperiids & 0.1 & 0.3 & 0.2 & + & - & \\
\hline Euphausiids & 94.4 & 96.4 & 85.80 & 29.9 & & 3.0 \\
\hline Shrimps & 4.6 & 3.2 & 2.0 & 1.0 & & 0.5 \\
\hline Sagitts & - & 0.1 & + & + & & - \\
\hline Squid & - & - & _- & 28.0 & & 50.5 \\
\hline Silver hake & 0.8 & - & 12.00 & 37.1 & & 17.0 \\
\hline Mackerel & - & - & - & - & & 25.0 \\
\hline White hake & - & - & - & - & & 2.0 \\
\hline Red hake & - & - & - & 2.0 & & 2.0 \\
\hline Sand eel & 0.1 & - & - & 2.0 & & - \\
\hline Total & 100.0 & 100.0 & 100.0 & 100.0 & & 100.0 \\
\hline
\end{tabular}

* No large males were observed in samples.

and pollock recruitment is shown in Fig. 17-19 (Rikhter, MS 1997). In some years silver hake population abundance and year-class size of the abovementioned species were observed to be inversely related. Appropriate correlation coefficients are shown below

\begin{tabular}{lrrr}
\hline Period (years) & Cod & Haddock & Pollock \\
\hline $1969-90$ & 0.22 & -0.28 & \\
$1979-90$ & -0.37 & - & \\
$1980-90$ & - & -0.42 & \\
$1972-89$ & & & -0.30 \\
$1977-87$ & & & $-0.64^{*}$ \\
\hline
\end{tabular}

* significant at 0.05 level.

These data show that within the overall observation periods, some shorter periods occurred when a negative correlation was found between silver hake abundance to the year of spawning and subsequent year-class size of silver hake or other species. In one case (pollock), a statistically significant relationship with $95 \%$ probability was found. Overall, these results provide no basis to state that there is a relationship between gadoid recruitment level and silver hake abundance. However, at least for pollock the possibility of such a relationship has some statistical support. Trophic interrelations seem to be one of the most probable reasons of an apparent inverse relation between recruitment of the above

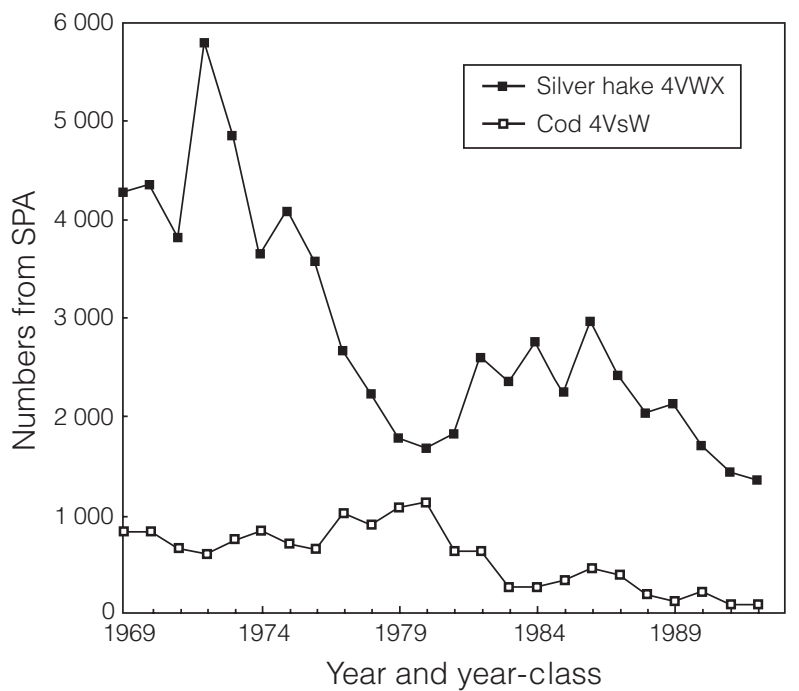

Fig. 17. Scotian Shelf silver hake population abundance by year, and one-year old cod abundance by yearclass (from Rikhter, MS 1997).

species and silver hake abundance. Food competition may play the major role since the results of previous research provided no evidence of intensive consumption of juvenile gadoids by silver hake in the area considered.

It should be mentioned as well, that the extent of various factors relevant to feeding impacts seems to vary among years. Unfortunately, no convincing data are available. We think this problem deserves to be researched in more detail. 


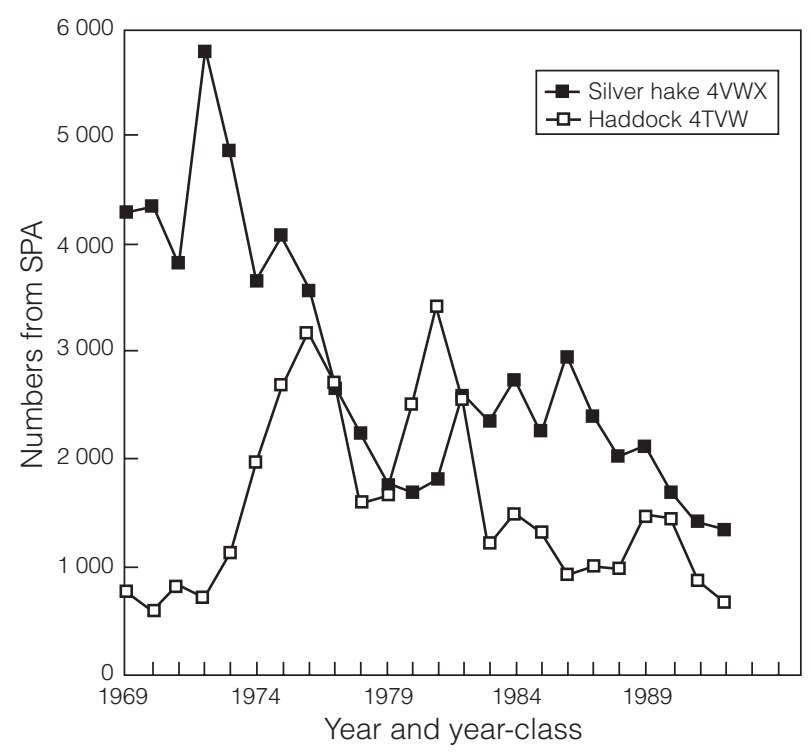

Fig. 18. Scotian Shelf silver hake population abundance by year, and one-year old haddock abundance by year-class (from Rikhter, MS 1997).

\section{Recruitment Rate and Natural Mortality}

During the early period of research age estimates of silver hake were in general biased. However, as noted earlier we consider the errors associated with age-1 group to be less biased. Therefore, we consider it reasonable to utilize age-1 data obtained before 1977 as well, to estimate the recruitment rate from the point of view of providing a general picture. Besides, we deal here only with relative estimates, which provide the possibility of at least rough comparison of estimates for the whole period considered (Table 15). The data presented show that variations of recruitment by year are rather large (from 26 to $69 \%$ ), which results mainly from age 1 year-class abundance variability. The fishery also may play a role, since during individual years considerable portions of the population (fish of age 2 years and older) are removed, resulting in recruitment proportion variability. To verify this hypothesis the estimates of recruitment rate were compared to those in periods of low and high level of fishing effort (Table 16). Respective data were taken from Clay and Beanlands (MS 1980) for 196378 and Showell (MS 1996) for 1979-95. Prior to 1963, as is known, the silver hake fishery was only intermittent. Periods from 1969 to 1976 and from 1977 to 1995 are particularly worthy of attention. It can be seen in the case of 1969-76, in spite of a high levels of fishing effort, the average recruitment rate exceeded the long-term average level (45\%), but in the case of 1977-95, average recruitment rate was below average

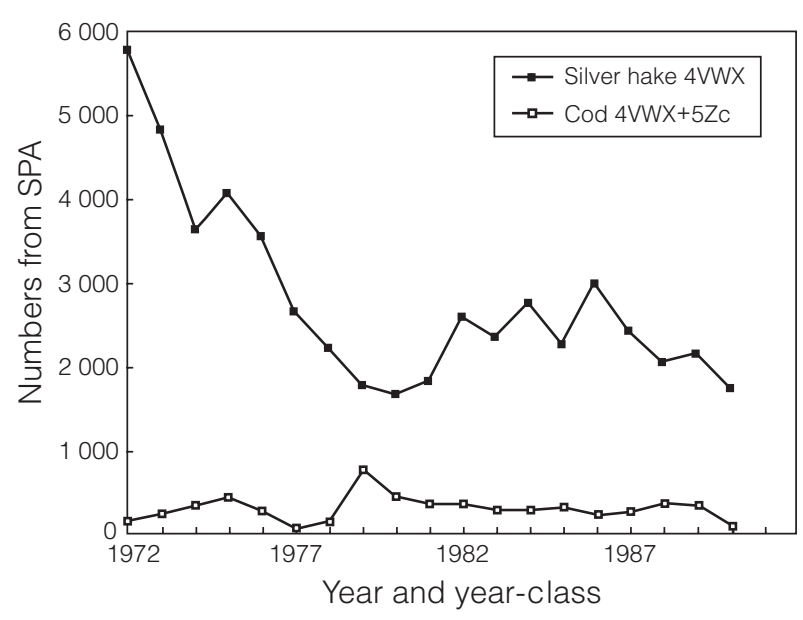

Fig. 19. Scotian Shelf silver hake population abundance by year, and two-year old pollock abundance by year-class (from Rikhter, MS 1997).

even though fishing effort decreased substantially. We interpret this to mean that the silver hake productivity level was comparatively high in 1969-76 and lower in the subsequent years. Consideration of the entire data series from 1958 allows us to conclude that, in spite of considerable inter-annual variations, the generally high recruitment rate of $45.1 \%$ on average is typical for this silver hake population.

With respect to the problem of considering a natural mortality value, it should be noted that the above conclusion would also assume a high rate of removal due to natural reasons. Terré and Mari (1978) attempted to provide a scientifically substantiated estimate of instantaneous natural mortality (M). On the basis of commercial and scientific information for 1963 to 1975 (inclusive), they estimated M to be 0.40 . However, $\mathrm{M}$ estimated on the basis of the relation between natural mortality and mass maturation age (Rikhter and Efanov, 1977) was 0.77.

Another attempt to assess average $\mathrm{M}$ was undertaken in 1988 (Rikhter, MS 1988) taking into account new fishery conditions after 1977 (the period after 200-mile zone implementation). Using different methods, the author estimated the coefficient to be 0.50 . Finally, to estimate $M$ in conditions of virgin or unfished stock, the approach that was used assumed approximate equality between the long-term average recruitment rate and natural mortality rate (Rikhter, MS 1996). It means that the long-term average of annual removal rate was also at the level of $45 \%$, (see above), which corresponds to instantaneous mortality rate $(\mathrm{M})$ of 0.60 . 
TABLE 15. Recruitment rate (RR) of Scotian shelf silver hake by year (Percentage of one-year-olds to total abundance)*.

\begin{tabular}{|c|c|c|c|c|c|c|c|c|c|c|c|}
\hline Year & 1958 & 1959 & 1960 & 1961 & 1962 & 1963 & 1964 & 1965 & 1966 & 1967 & 1968 \\
\hline RR & 62.6 & 58.3 & 59.1 & 61.1 & 58.8 & 39.9 & 27.9 & 31.4 & 50.1 & 61.5 & 61.8 \\
\hline Year & 1969 & 1970 & 1971 & 1972 & 1973 & 1974 & 1975 & 1976 & 1977 & 1978 & 1979 \\
\hline RR & 62.6 & 39.9 & 49.7 & 68.6 & 36.2 & 55.0 & 53.2 & 38.2 & 29.8 & 26.0 & 51.1 \\
\hline Year & 1980 & 1981 & 1982 & 1983 & 1984 & 1985 & 1986 & 1987 & 1988 & 1989 & 1990 \\
\hline RR & 39.7 & 47.7 & 59.2 & 34.9 & 48.8 & 32.8 & 60.7 & 33.0 & 36.6 & 51.0 & 39.7 \\
\hline Year & 1991 & 1992 & 1993 & 1994 & 1995 & & & & & & \\
\hline RR & 43.5 & 52.8 & 51.6 & 42.1 & 50.9 & & & & & & \\
\hline
\end{tabular}

* Prior to 1979, data by Clay and Beanlands (MS 1980) were used, subsequent data by Showell (MS 1996).

TABLE 16. Periods of silver hake fishing at various levels of fishing effort and appropriate average recruitment rate (RR) values.

\begin{tabular}{lccccc}
\hline \hline Fishing period & $1958-62$ & $1963-65$ & $1966-68$ & $1969-76$ & $1977-95$ \\
\hline Fishing effort & Absent or very low & High and moderate & Very low & High and very high & Low and moderate \\
\hline RR & 60.0 & 33.1 & 57.8 & 50.4 & 38.8 \\
\hline
\end{tabular}

The lower estimates, obtained from earlier data, may be explained by a decrease of natural mortality under the impact of intensive fishery during appropriate years. This idea was likely expressed for the first time by Baranov (1925) while in the paper by Tiurin (1962) a plot was presented to estimate natural mortality rate variability in relation to fishery intensity. Tretiak (1984) concluded that the long-term intensive fishery of Arctic-Norwegian cod resulted in a decrease of $\mathrm{M}$ for fishes of similar age. Therefore, release of fishery pressure should have an opposite effect, i.e. the rate of removal due to natural reasons will increase when a stock approaches the level corresponding to a non-fished stock.

One more aspect of natural mortality assessment that should be mentioned is its variability by age. At present, nobody doubts that such variability exists. Examples of $\mathrm{M}$ increasing with age presented in Ricker (1975). Beverton and Holt (1957) note the possibility of $\mathrm{M}$ changing in both directions as age increases. Theoretical considerations by Tiurin (1962), however, suggest an inevitable increase of natural mortality, starting from a specific age. Presumably, utilization of $\mathrm{M}$ varied by age in analytical models should improve fish population abundance estimates. Nevertheless, world experience of fishery research provides very few examples of estimation and utilization of M specific to each age. Such examples for the Northwest Atlantic area are as follows: Rikhter (1972), Clay and Nielsen (MS 1985), Noskov (MS 1985), Efimov et al. (MS 1986), Waldron (MS 1989) and Rikhter (MS 1991).

The last attempt to estimate $\mathrm{M}$ values for Scotian Shelf silver hake by age made by Rikhter (MS 1991) was based on the methodical approach used to assess M of red hake (Urophycis chuss) (Rikhter, 1972). The adjusted $\mathrm{M}$ estimates by age are shown below, which differ slightly from those by Rikhter (MS 1991).

\begin{tabular}{lllllll}
\hline Age & 1 & 2 & 3 & 4 & 5 & 6 \\
\hline M & 0.648 & 0.679 & 0.286 & 0.382 & 0.571 & 0.594 \\
\hline
\end{tabular}


These calculations indicate that the lowest $\mathrm{M}$ is on the age-3 group, which corresponds to the age of complete maturity and vulnerability to fishery impact (partial recruitment equal to 1). For fish older than 6 years, $M$ seems to increase further. However, the lack of appropriate information eliminates the possibility of estimating the rate of such an increase. From a stock assessment point of view this is not critical due to extremely low silver hake abundance at the age of 7 years and older.

Unfortunately, the issue of sex differentiated values of silver hake natural mortality remains beyond consideration. The stock assessments provided by individual scientists and scientific bodies of ICNAF and NAFO were based only on combined M values. However, differences observed in life duration of males and females have provided a lead to the assumption of different $M$ values by sex. In males, $M$ values seem to be considerably higher. To some extent, there may be evidence of this in Noskov (MS 1985), who attempted to estimate $Z$ by sex and age. According to his data, $Z$ values in males at age $4-5$ years and at 56 years significantly exceeded those for females. We project that this was likely caused by the higher rate of male natural mortality at the specified ages.

To conclude this section, it should be stated, that fixed value of silver hake natural mortality coefficient, used during past assessments by NAFO Scientific Council may be rather far from actual mortalities. In our opinion, differences in age and sex based mortalities require further and more detailed study.

\section{Variation of 0-group and 1 Year Old Fish}

\section{Abundance}

The results of young fish (0-group) trawl surveys, carried out every year under the joint USSR/Russia and Canada program in October-November from 1981 to 1997 , provided the first and relatively objective picture of Scotian Shelf silver hake year-class abundance. In an earlier section describing distribution during the first year of life, the reasons were provided to explain why data of surveys carried out in 1977-80 cannot be used together with data from subsequent surveys. Estimates at age 1 were provided from Canadian trawl survey data collected annually in July. Abundance indices of 0-group and one year old silver hake using data taken from Showell (MS 1997) are shown in Fig. 20. The data provide evidence that during the $1980 \mathrm{~s}$ there was a good relation between the two independent series of observations. Therefore, it may be stated that strong year-classes of

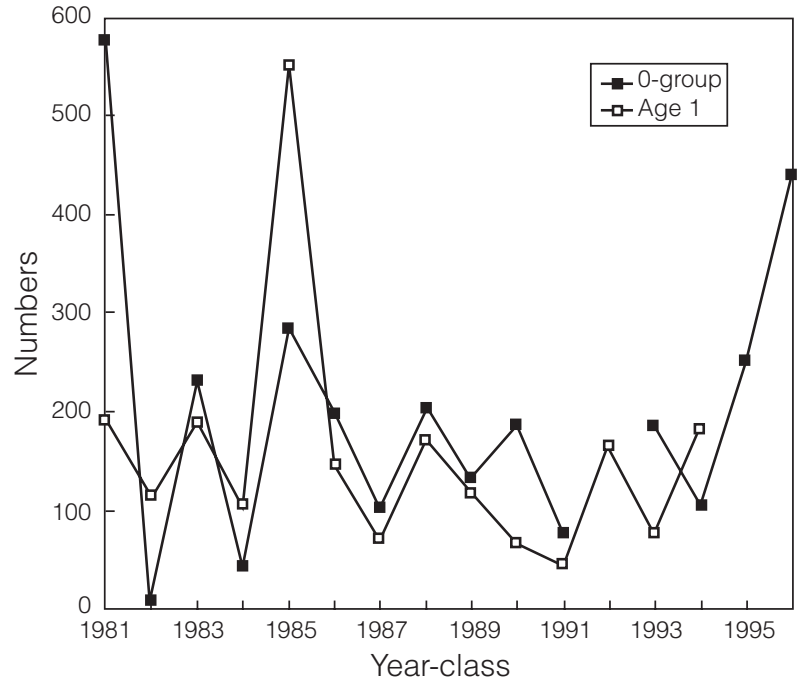

Fig. 20. Dynamics of abundance indices of 0-group and one-year-old silver hake by year-class.

silver hake appeared in 1981, 1983, 1985 and 1988, and the year-class of 1985 was the strongest. If we consider the first half of $1990 \mathrm{~s}$, the picture is not so clear. Then, abundance indices of 0 -group and one year old hake of the 1990, 1993 and 1994 year-classes were in disagreement regarding strength (Showell, MS 1997). If we assume that estimates based on one year old fish abundance are more reliable compared to those from 0 -group surveys ( $p>0.95)$, the year-classes of 1990, 1991 and 1993 should be specified as weak, while the year-classes of 1992 and 1994 considered as relatively abundant.

The correlation between indices of 0 -group and one year old fish, estimated for year-classes of 198394, was 0.66. Indices of 0-group for 1981 and 1982 were not included in calculations because of "concern over standardization of survey protocol during these years" as was noted by Showell (MS 1997).

Abundance estimates obtained using VPA methods constitute the third source of information of year-class abundance dynamics. Taking data from Clay and Beanlands (MS 1980) together with those from Showell (MS 1996), we obtain a series of observations of year-class strength at ages covering the period from 1958 to 1995 inclusive. These VPA estimates are not taken as absolute estimates, but only viewed from the perspective of indicating recruitment (age group 1) abundance trends.

Figure 21 presents the general trend of abundance variability of one-year old silver hake. The picture 


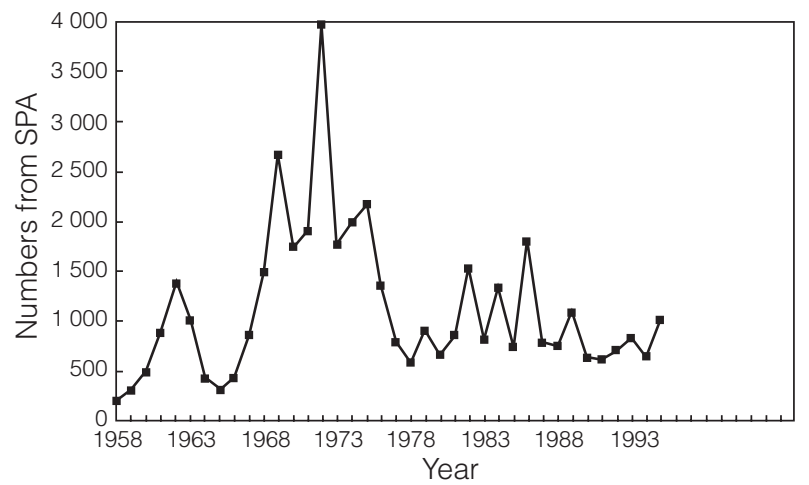

Fig. 21. Dynamics of one-year-old silver hake (VPA) by year from Clay and Beanlands (MS 1980), years 1958-78, and Showell (MS 1996), years 1979-95.

obtained suggested three periods of relatively strong year-class occurrence, associated with the first half of 1960s, late-1960s to mid-1970s and first half of 1980 s. On the whole, the pattern of abundance variation for the year-classes is in conformity with data on recruitment rates (Tables 15, 16).

The extent of variability in one-year-old abundance estimates (from VPA) before and after the declaration of the EEZ in 1977 should be noted. Prior to 1979 (Clay and Beanlands, MS 1980) the coefficient of variation (CV) based on survey data was considerably higher than from 1979 to 1995 (Showell, MS 1996) (72\% and 37\%, respectively). Estimates of silver hake total population biomass (from VPA) and abundance showed similar differences in variability for the periods considered (Rikhter, MS 1994). The reasons for such big differences in estimates by periods are considered in Rikhter (MS 1994). In our opinion the considerable differences in variability of the indices before and after the introduction of the 200-mile EEZ most likely result from the restrictions placed on the silver hake fishery, which have come into force since 1977.

The high inter-annual variability in abundance of the silver hake population on the Scotian Shelf is likely determined by environmental factors. As regards the role of the fishery, it is noted that even in the years when the exploitation rate on this species was not restricted, its abundance fluctuations seemed to be affected by hydrological conditions on the shelf. This was all the more apparent since the fishing pressure could not affect seriously the inter-annual variability of silver hake abundance after the introduction of the 200-mile EEZ in 1977.

\section{Silver Hake Abundance Fluctuations}

Based on the peculiarities of the hydrological regime in the Scotian Shelf area, it may be assumed that the advective processes on the Shelf play the most important role in formation of silver hake habitat conditions. Since the thermal structure of water in the area is a product of interactions between warm slope and cold Labrador waters, any variations in their proportion may result in either favourable or unfavourable conditions. Advection affects all components of the hydrological regime, primarily the temperature conditions, which are closely linked to the silver hake life cycle.

Sigaev (1992) compared silver hake year-class abundance at age 1 with inter-annual variability of external environmental conditions on Scotian Shelf and adjacent areas (Fig. 22); the indices reflecting the advective processes. Minimum temperature of the cold intermediate layer in Emerald Deep may be one of the important indices, as its variations indicate enhancement or weakening of cold-water advection on the shelf. The other indicator of warm slope water advection extent is the depth of the $5^{\circ} \mathrm{C}$ isotherm in Emerald Basin. The greatest depth of this isotherm was observed in the mid-1960s and the least in the mid-1970s (Sigaev, 1969, MS 1979). Such indices as hydrological front boundary locations at the surface, and the north/south spatial shift which reflects the advective variations on different temporal scales, may be used as other indices of advection (Sigaev, 1986, MS 1991, MS 1993, 1996a). Besides these, sea surface temperature in the shelf areas occupied by waters of different origin was tested. Since advective variations in the intermediate layer are related to conditions in the areas located northeastwards, one of the indices reflecting conditions in those areas, namely average monthly water temperature in January at Station 27 (St. John's, Newfoundland) was tested using the data reported by Akenhead (MS 1983). The presentations using Sigaev's data, found positive relationships of abundance of one-year-olds with minimum temperature of the cold intermediate layer in Emerald Basin $(r=0.48)$ and the location of the warm Slope water boundary ( $r=0.63$ ) (at 95\% significance level). An inverse relationship of abundance of one-year-olds to the temperature at Station 27 was found $(r=-0.32)$ but this was not significant. The latter seems to be explained by the fact that, during the years when air temperature and sea surface temperature increases in the areas located northeastern of the Scotian shelf, cold water transport southward may be enhanced due to increases in rainfall and ice melting which results 


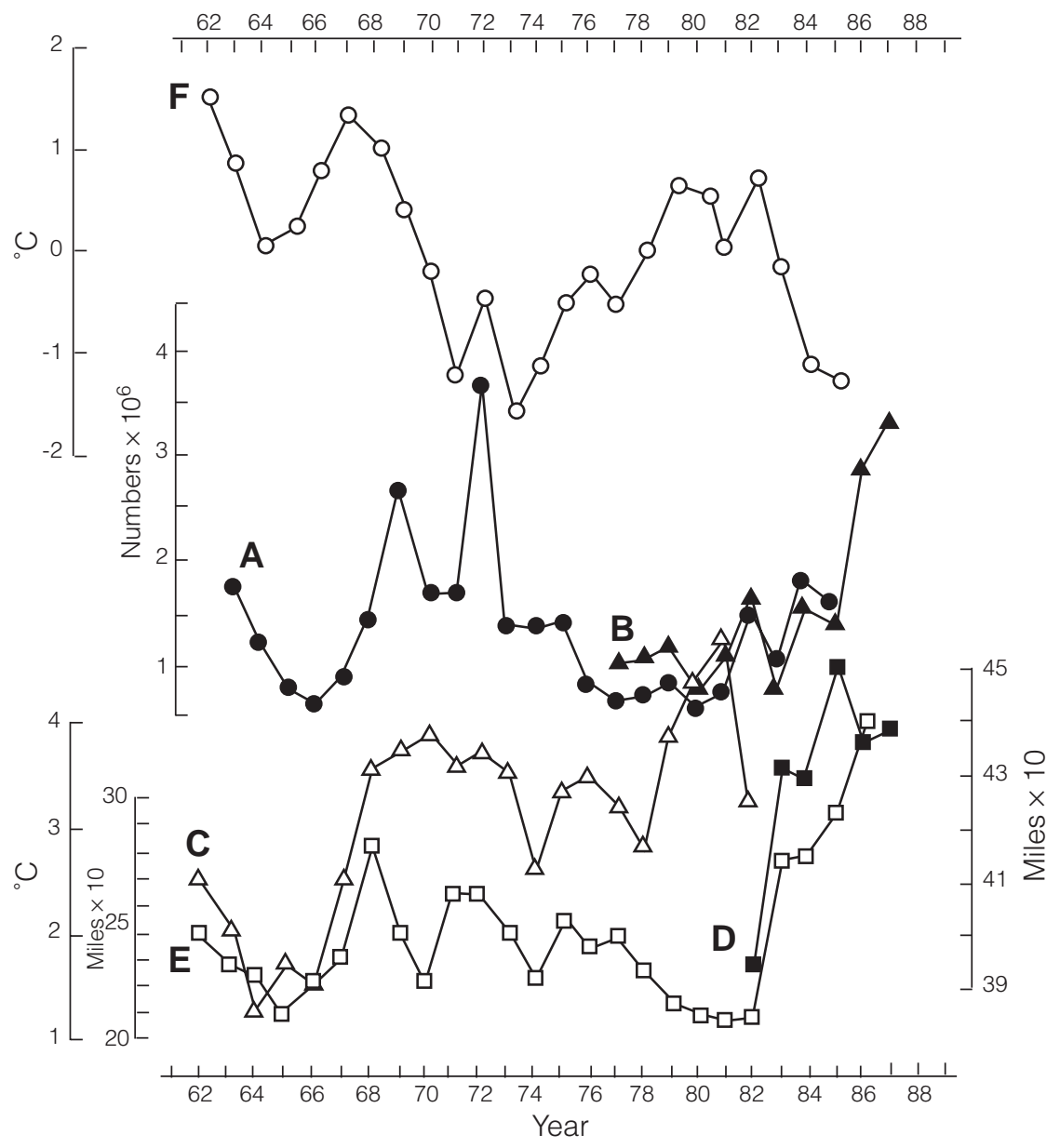

Fig. 22. Variations of one-year old silver hake abundance on the Scotian Shelf over 1963-87 and environmental characteristics 1962-87: (A) abundance of 1-year-old silver hake according to Clay and Beanlands (MS 1980) before 1970, and Waldron et al. (MS 1988) after 1970; (B) abundance of 1-yearold silver hake according to Rikhter (MS 1989; (C) minimum values of the water temperature in the cold intermediate layer (means for summer and autumn); (D) index of cold shelf water boundary localization on the surface (means for August and October); (E) index of slope water boundary localization on the surface (means for August and October); (F) mean temperature in January at climate station, 27, St. Johns, Newfoundland (from Sigaev, 1992).

in an increase in volume of water in the cold intermediate layer in summer. As a result, the conditions for silver hake spawning may deteriorate. Thus silver hake year-class abundance in relation to the temperature conditions may be revealed by SST variability.

Sigaev and Rikhter (1996) found positive relationships between age 1 abundance and average annual SST values at $45^{\circ} \mathrm{N}, 60^{\circ} \mathrm{W}$, located in the cold water mass of Labrador origin within the shelf $(r=$
0.52 ) and with SST values at $42^{\circ} 30^{\prime} \mathrm{N}, 62^{\circ} 30^{\prime} \mathrm{W}$, located in the warm slope water near the shelf slope ( $r=0.73$ ) (both significant at 95\% level). Those locations were selected as reference points to monitor inter-annual and seasonal variability of SST from 1977 (Sigaev, MS 1993). A positive, but non-significant ( $r$ $=0.22$ ) relationship, was revealed by Sigaev and Rikhter (1996) between abundance index of one-yearold silver hake and fluctuations of cool shelf water boundary based on the data for 1977-91. A similar relationship between these indices was also found 
during the shorter time period (1985-93 and 1995) (Sigaev, 1996a), (Fig. 23). If the pattern of all relations mentioned persists in future it will be possible to proceed to more strict statistical estimations. Southward shift of the boundary promotes an increase of cold-water mass volume in the intermediate layer. This decrease in temperature may result in a delay of optimal temperature occurrence on the spawning grounds and a delay in mass spawning, which in turn results in deterioration of survival conditions at early stages resulting in weak year-classes. Northward shifts of the cold-water boundary may have an opposite effect. Therefore, the examples shown provide evidence that the abundance of Scotian Shelf silver

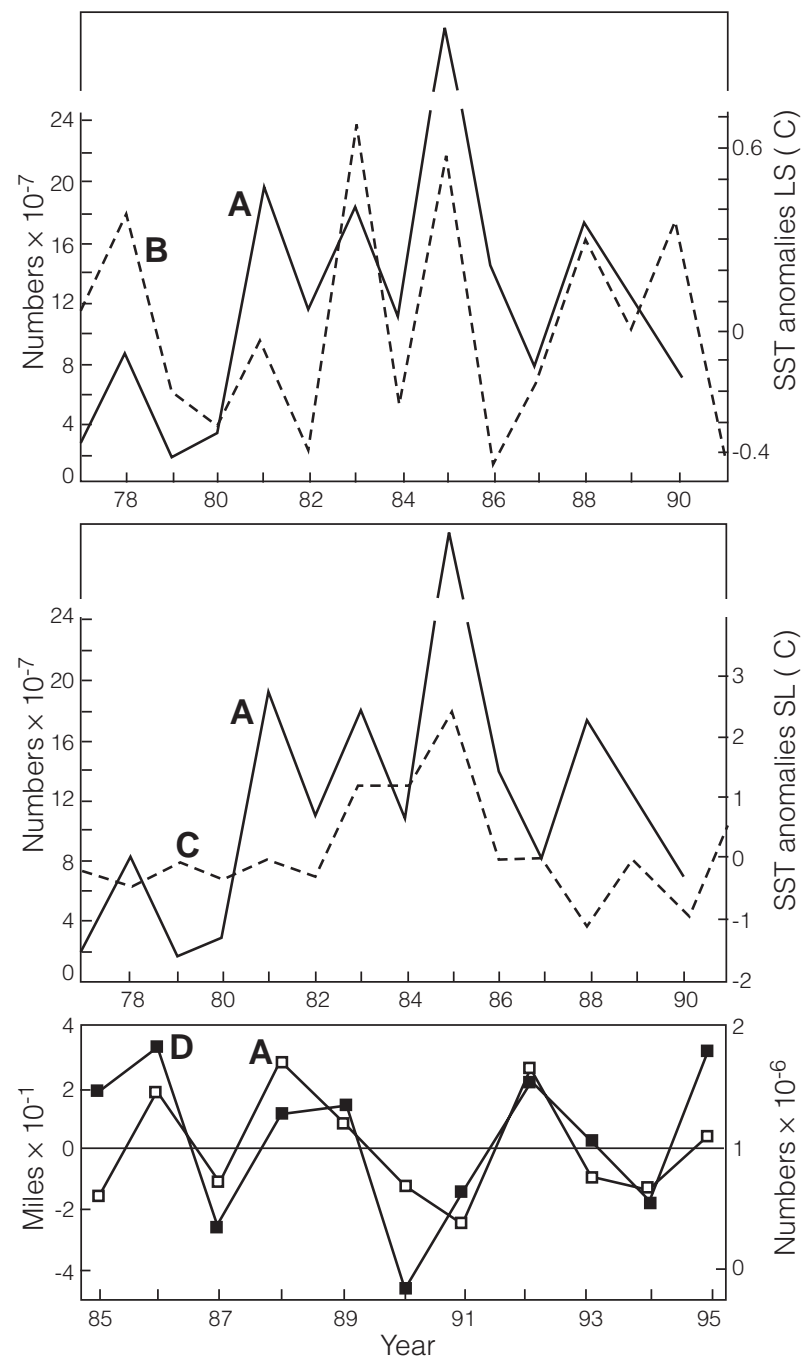

Fig. 23. Interannual variations of 1-year old silver hake (A) and SST of Labrador current (B), SST of slope water (C) (Sigaev and Rikhter, 1996), and boundary of cold shelf water in spring (D) (Sigaev, 1996a). hake may be significantly affected by oceanographic conditions.

AtlantNIRO scientists considered also other factors as probable reasons for sharp fluctuations in recruitment. Noskov et al. (MS 1982) assumed that survival of eggs depends on surface water temperature and sea conditions, while that of larvae depends on food availability, especially during the period of transition into active feeding. Considerable attention was paid to research of relationships between surface temperature in winter, abundance of forage organisms, 0 -group condition and subsequent survival of young fish (Noskov and Sherstyukov, 1985; Sherstyukov, MS 1991 a, b). Statistically significant positive correlation was found between fry condition and zooplankton abundance, and significant negative correlation was found between mortality rate and surface temperature in winter. The research conducted leads to the conclusion that silver hake year-class strength had not been determined only during the 0 -group stage but continued during the winter. Thus it may be assumed that high abundance of fry in autumn does not guarantee the appearance of a strong year-class at age 1 .

\section{Stock-recruitment Relation}

The existence of stock-recruitment relationships (SRR) is beyond any doubt, however, the relationships are often difficult to detect. Gulland (1973) noted the masking effect of recruitment fluctuations, which are independent of parental stock abundance variations. If such fluctuations are low, appropriate fishing measures should lead to the stock recovery. However, if abundance variations independent of spawning biomass size are considerable, the danger of overfishing becomes real, since stock independent fluctuations may not be predictable.

The first attempt at SRR analysis for Scotian Shelf silver hake was made by Rikhter (1988), using Shepherd's model (1982) with the following parameters: $a=0.018, K=0.164, b=1.8$. These parameters were used to calculate the location of points on the plot followed by adjustment of the curve to those points (Fig. 24). The curve was fitted with extrapolation beyond the observed (estimated with VPA) minimal size of spawning stock biomass (age of 3 years and older) using data taken from Waldron et al. (MS 1988). The curve obtained was similar to the Ricker-type (Ricker, 1954). However, it should be noted that Shepherd's equation parameters were selected using ad hoc methods, based to a large extent 
on theoretical considerations. Therefore, it is not surprising that the correspondence between the observed (estimated with VPA) and predicted recruitment values was rather low $(r=0.48)$ and not significant at $95 \%$ level. During the period considered, the weakest year-classes and the lowest spawning biomass levels were observed in 1975-80 (Fig. 25). Recruitment stabilized at a low level and continued until conditions of survival at early stages of development became more favorable. In this connection, 1981 should be noted as the start of a new period of stock increase.

The second calculation of a relationship between recruitment and spawning biomass was also carried out by Rikhter (MS 1990). In this case parameters of SRR were defined using four classic equations (Beverton and Holt, 1957; Ricker, 1954; Cushing, 1971; Chapman, 1973) to reveal which equation provided the best description of the actual data. Correlation coefficient (r) and cumulative deviation between estimated and observed data (D), as well as standard deviation (d) of estimated recruitment values, were used as criteria for judging best fit. These characteristics are presented in Table 17.

On the basis of the data presented it is not possible to determine which relationship is the most appropriate. However, Chapman's equation was preferable for two parameters ( $D$ and $d$ ), with the following coefficients: $a=0.1840, b=-0.0648$. The relationship is shown in Fig.26, from which it is evident that during the period considered (1970-86) the rate of silver hake recruitment rose with spawning biomass increase. It is likely the result of extremely favorable environmental conditions for strong yearclass formation occurred during appropriate years.

A curve drawn by eye on the basis of the observed data for 1979-95 (Showell, MS 1996), reveals a trend similar to that of the previous analysis within the biomass range of 150000 to 200000 tons (Fig. 27). Within this range, recruit abundance fluctuated sharply which would hardly be explained by the effect of the spawning biomass alone. The reason, evidently, should be found in variability of environmental factors. As is seen from the previous section, occurrence of strong silver hake year-classes, as a rule, was associated with the period during which Scotian Shelf water became warmer while poor year-classes were observed when shelf water cooled. Evidently, the curve shown in Fig. 27 provides a more realistic picture of the situation than that obtained with Shepherd's method (Shepherd, 1982).

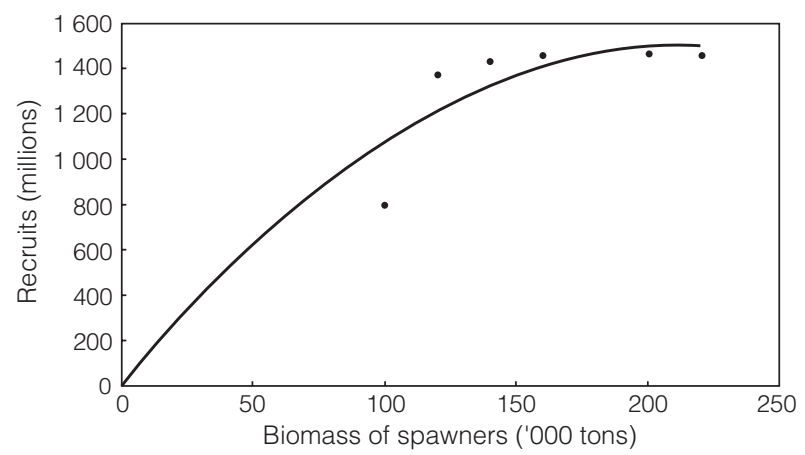

Fig. 24. Stock-recruitment relation of Scotian Shelf silver hake estimated according to Shepherd (1982) equation.

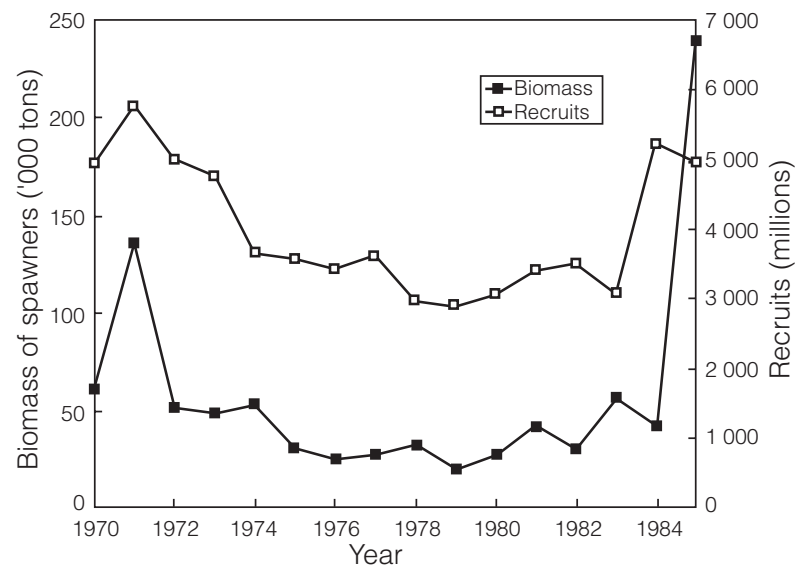

Fig. 25. Dynamics of silver hake recruitment and spawning stock in 1970-85.

TABLE 17. Comparative characteristics of four versions of stock-recruitment relation from Rikhter (MS 1990).

\begin{tabular}{lccc}
\hline \hline Equation & $r$ & $D$ & $d$ \\
\hline Beverton and Holt, 1957 & 0.71 & 5576 & 1424 \\
Ricker, 1954 & 0.75 & 6397 & 1397 \\
Cushing, 1971 & 0.73 & 6524 & 1379 \\
Chapman, 1973 & 0.74 & 5519 & 1351 \\
\hline
\end{tabular}




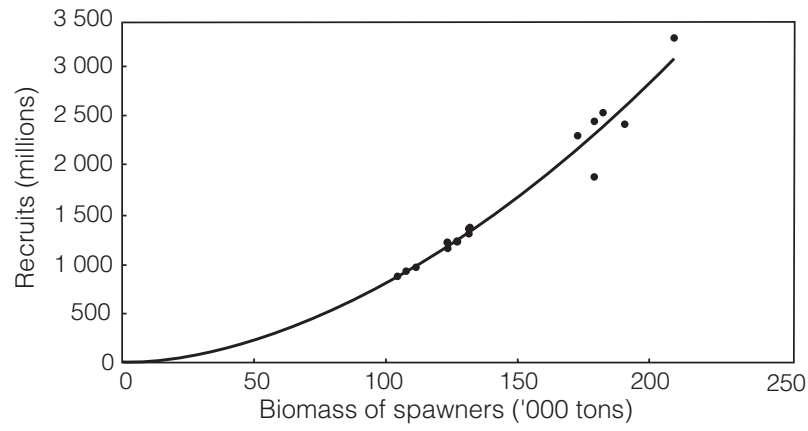

Fig. 26. Stock-recruitment relation of Scotian Shelf silver hake estimated according to Chapman (1973) equation.

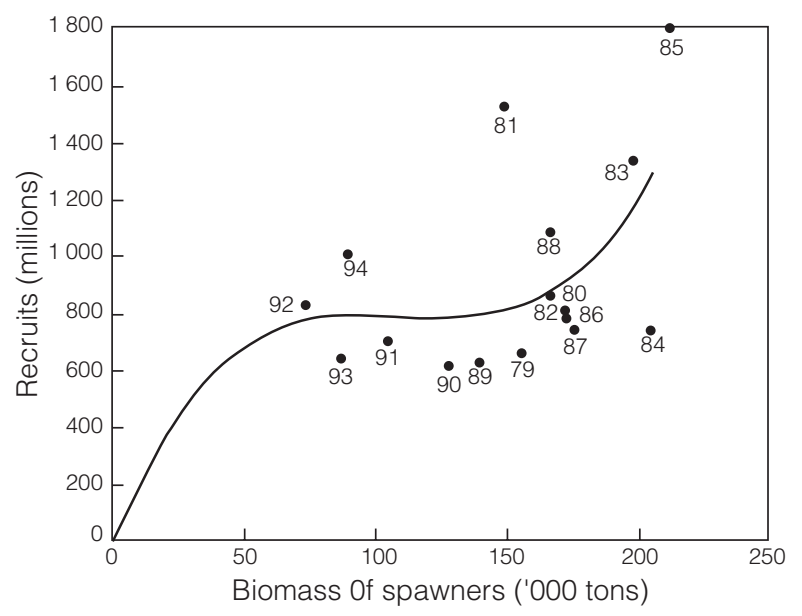

Fig. 27. Stock-recruitment relation of Scotian Shelf silver hake observed in 1979-95 (trend type polynomial).

Based on the above considerations it can be assumed that, for Scotian Shelf silver hake, the environmental factors (apparently oceanographic ones) override density dependent effects during particular periods. Therefore, spawning stock biomass cannot be used in predictions of recruitment without consideration of environment trends.

Let us return back to the period of 1975-80 when both spawning biomass and recruitment of Scotian Shelf silver hake were at relatively stable and low levels. Such an occurrence is not unusual since a similar picture was also observed in silver hake on Georges Bank and off New England in 1955-58, as well as in mackerel of the Atlantic in 1962-65 (Rikhter, MS 1990). The spawning stock size alone was likely insufficient to produce strong year-classes at the "normal" environmental conditions which occurred in those years. In similar cases, the environmental conditions would need to be particularly favourable for silver hake survival at early development stages for strong year-class formation.

\section{Prediction from Trends in Abundance Variations}

The historic information we have reviewed lead us to believe that data on recruitment abundance in relation to oceanographic factors, and on the spawning stock biomass and its impact on recruitment abundance, provide a basis for prediction of abundance variations. Probable exploitation rate of the population considered can also be taken into account for the period covered by the prediction. Taking into consideration the above, we have attempted to forecast what may be expected during the late-1990s and the first decade of the next century. Retrospective estimates of abundance and biomass have been used as the basic information, which allows major periods of silver hake stock increase and decrease to be defined for a long series of years (Table 18).

The indications are that the period of high level of silver hake abundance may last from 3 to 8 years while that of low levels from 4 to 8 years (Table 18). In addition, the pattern of recruitment and stock abundance shows some recurrence. Assuming that each cycle includes phases of stock and recruitment increase and decrease, we can specify approximately cycles of recruitment (abundance of 1 year old fish) and that of the exploitable stock (fish biomass at the age 2 years and older) for the entire period of observations, as follows:

\begin{tabular}{lllll}
\hline Recruitment cycle & $1960-66$ & $1967-80$ & $1981-93$ & $1994-$ \\
Stock cycle & $1962-68$ & $1969-82$ & $1983-95$ & $1996-$ \\
\hline
\end{tabular}

Let us consider the last cycle, which started as the previous ones with the phase of increase, and follow the probable sequence of events for the next several years. The evidence available confirms that the 1995 year-class is a strong one (Showell, MS 1997). Preliminary estimation of 1996 and 1997 yearclass abundance (data of young silver hake surveys) shows that those year-classes substantially exceeded the average level. According to Showell (MS 1997), in early 1997 a sharp increase of silver hake fishable biomass actually occurred. Unfortunately we have no reliable data on its stock size in subsequent years on the basis of the above and taking into account the expected low rate of exploitation during the most recent years, we assume that at least till year 2000 
TABLE 18. Periods of silver hake recruitment and commercial stock abundance in relation to the mean for 1960-95 (number of years in each period given in parentheses).

\begin{tabular}{lcccc}
\hline \hline \multicolumn{1}{c}{ Periods description } & \multicolumn{4}{c}{ Periods } \\
\hline $\begin{array}{l}\text { Recruitment abundance is mainly above } \\
\text { the average level (1-year old fish) }\end{array}$ & $1960-62$ & $1967-75$ & $1981-85$ & $1994-96$ \\
& $(3)$ & $(9)$ & $(5)$ & $(3+)$ \\
$\begin{array}{l}\text { Recruitment abundance is mainly below } \\
\text { the average level }\end{array}$ & $1963-66$ & $1976-80$ & $1986-93$ \\
Commercial stock abundance (2 year old fish and older) & $(4)$ & $(5)$ & $(8)$ \\
is mainly above the average level & & & & 1996 \\
& $1962-64$ & $1969-76$ & $1983-87$ & $(5)$ \\
Commercial stock abundance is mainly below & $(3)$ & $(8)$ & $(1+)$ \\
the average level & $1965-68$ & $1977-82$ & $1988-95$ & $(8)$ \\
\hline
\end{tabular}

the fishable biomass will be at a relatively high level. Taking into consideration the data of Canadian surveys of July 1999-2000, evidencing that 1998 and 1999 year-classes are at the level higher than average (DFO, 2000) and oceanographic data (Sigaev et al., 2000) according to which the conditions on the Scotian Shelf during the above said years were favourable for strong year-classes formation, the assumption concerning the period of relatively high silver hake population abundance may be extended for 2-3 years more. However it is noted that these factors can change in the short and long timeframes.

The situation after 2000 is more difficult to predict. Certainly, high spawning biomass, based on the pattern of stock-recruitment relation (Fig. 26, 27) to some extent, may become a factor favourable to strong year-class formation. However, a sharp deterioration of environment conditions for survival at early stage of development may eliminate the effect of the latter. Therefore, it is necessary to evaluate the trends of oceanographic characteristics, which seem to affect silver hake year-class abundance (see above).

To provide a prognosis of the situation with silver hake abundance for the next 3-4 years, attention should be primarily paid to the trends of environmental conditions, which seem to promote occurrence of several strong year-classes. Those trends associate with two synchronous processes, i.e. increase of cold Labrador water inflow into the northeastern part of the shelf, and increase of warm slope water advection into deepwater part of the shelf. The first process is promoted by an increase of air and sea surface temperature and reduction of marine ice cover in Labrador Sea, Newfoundland and the Gulf of St. Lawrence (Drinkwater et al., MS 1997a,b; Colbourne, MS 1997), which have been particularly pronounced since 1994. Variations in the atmospheric circulation field over the Northern Atlantic (the North Atlantic Oscillation-NAO) observed during the latest decade, seem to be the main reasons for the latter trends (reference?). A typical indicator of development of major atmospheric impact centers over the North Atlantic is the difference of pressure between the Azores maximum and Iceland minimum, which shows a declining trend from 1991. This results in a decrease of northwestern winds and transport of cold air masses from Arctic regions which in turn causes the above mentioned trends in ice conditions, air and water temperature (Drinkwater et al., 1997a).

The second process, observed on the Scotian Shelf results both in temperature increases in the nearbottom layer and in increases in the area occupied by warm Slope water. Drinkwater et al. (MS 1997a) showed two peculiarities appeared in the Scotian Shelf area. The first one is that from the mid-1980s the low temperature period has retained in the intermediate cool layer, in the near-bottom layer of the northeastern shelf and near-surface waters shore along the Atlantic coast of Nova Scotia. Unlike the first one, the second peculiarity is that from the same time (except for 1991 and 1992) in the central shelf area, in Emerald Basin and along the Continental Slope the period of high temperatures was observed especially after 1992. Water temperature anomalies have been recorded in most parts of the Gulf of Maine from 1993, which indicate warm Slope water advection. Two opposite processes, i.e. increase of cold water advection from 
the Northeast and warm slope water into the deepwater part promote increases in temperature gradients and stir up productivity processes at the boundary of warm and cold waters, creating favourable conditions to strong year-class formation. The environmental trends shown above seem not to have entered the final stage and may persist in 1998-2000. On the basis of the above, we may assume that year-classes with abundance above the average level will appear at least until 2000 (for the period of 6-7 years). As showed the results of the latest researches, the abovementioned environment trends have been observed also in 1998-2000 (Sigaev, 2000). In such case, the phase of high commercial stock abundance will continue to 2003.

We note that this is a schematic picture of events which could be expected in the nearest future. However, occurrence of unpredictable anomalies of environment cannot be ruled out which may significantly affect this.

\section{Conclusion}

Silver hake on the Scotian Shelf is a selfreproducing stock. During most of the year silver hake is a demersal species and aggregates in deepwater depressions of the shelf and in warm Slope water. The spawning period (July-September) is an exception when large numbers occur in the shallow area off Sable Island. This population is distributed in the northeastern extremity of the species distribution area and therefore is frequently affected by climatic variations.

Based on abundance dynamics (relatively short life cycle, early maturation, high rate of recruitment and losses due natural causes) silver hake is classified as a species with a high productivity, which is characterized by sharp abundance fluctuations. Abundance may decline by several fold and recover to its original value during a short period of time (2-3 years). The sharp variations of year-class abundance are caused by environmental variability, variation in advective processes playing the major role.

Regarding the stock-recruitment relationship, the impact of spawning stock size on recruitment is entirely masked or, more precisely, suppressed by the impact of environmental factors within a wide range of spawning biomass. Only at extremely low values of spawning biomass can the delay in stock recovery be observed related to spawner biomass, and low abundance may continue until the occurrence of a combination of environmental factors especially favourable to year-class abundance formation. The pattern of Scotian Shelf silver hake abundance dynamics makes it difficult (if not impossible) to estimate the optimal (target) level of spawning biomass, which provides the most probable successful recruitment (annual appearance of sufficiently strong year-classes).

Trends in the silver hake population abundance during the late-1990s and the first decade of Twenty first century, based on the data on the stock dynamics since 1960, and relations between recruitment abundance and oceanographic factors, are predicted to be favourable with regards to relatively strong yearclasses during this period. Certainly, even in such a case, year-class abundance fluctuations are unavoidable. However, the total stock biomass in general is expected to remain at a fairly high level.

The role of silver hake in the Scotian Shelf ecosystem is still insufficiently researched. We may only suppose that, taking into account high abundance of this species and partial overlap of ecological niches with those of other fish species (especially of gadoids), the role of silver hake in the Scotian Shelf ecosystem should be considerable.

\section{Acknowledgements}

We thank A. S. Noskov (AtlantNIRO) for leading the research on silver hake on the Scotian Shelf during many years, and the scientists and technical personnel of AtlantNIRO, and the Fishing Scouting Service for sampling and processing of respective biological and oceanographic materials.

We are also very grateful to T. V. Khoulga, N. L. Samovarova, and L. Ya. Karpiy for their enormous work on translation and technical preparation of the manuscript.

We express our sincere gratitude to R. G. Halliday and D. B. Atkinson for their constructive review of the manuscript, which considerably improved its quality.

\section{References}

AKENHEAD, S. A. MS 1983. Mean temperatures and salinities from ocean climate station by Newfoundland. NAFO SCR Doc., No. 30, Serial No. N682, 28 p.

BARANOV, F. I. 1925. Fishery and extreme age of fishes. Fish. Bull., 9: 7-11.

BEVERTON, R. I., and S. J. Holt. 1957. On the dynamics of exploited fish populations. Fish. Invest., Ser. No. 2., Vol. 
19, London, $533 \mathrm{p}$.

BOWMAN, R. E., and E. W. BOWMAN. 1980. Diurnal variation in the feeding intensity and catchability of silver hake (Merluccius bilinearis). Can. J. Fish. Aquat. Sci., 37(10): 1565-1572.

BRANTON, R. M., R. G. HALLIDAY, and M. A. SHOWELL. MS 1997. Effects of modification to the Scotian Shelf small mesh gear line in 1994-1996 on catch rates of silver hake. NAFO SCR Doc., No.47, Serial No. N2881, 12 p.

BRYANTSEV, V. A. 1962. Water masses distribution in Scotian Shelf area. Trudy BaltNIRO, 9: 131-136.

1963. Water masses of Scotian Shelf area. Trudy AtlantNIRO, 10: 15-18.

1967. Characteristic, distribution and wind driven shift of water masses in Scotian shelf area. Oceanological researches in Atlantic Ocean. Kaliningrad, AtlantNIRO, p. 104-114.

BRYANTSEV, V. A., and I. I. FILATOV. 1969. On relation between near-bottom water temperature and hake concentration. Fisheries, 4: 8-10.

CHAPMAN, D. G. 1973. Spawner-recruit models and estimation of the level of maximum sustainable catch. ICES Rapp. Proc.-Verb., 164: 375-389.

CLAY, D. MS 1980. Assessment of the silver hake (Merluccius bilinearis) stock in Divisions $4 \mathrm{VWX}$, using provisional 1979 data. NAFO SCR Doc., No. 4, Serial No. N053, $12 \mathrm{p}$.

CLAY, D., and D. BEANLANDS. MS 1980. Silver hake (Merluccius bilinearis) in Divisions 4VWX: a stock assessment and estimate of total allowable catch (TAC) for 1981. NAFO SCR Doc., No. 87, Serial No. N141, $14 \mathrm{p}$.

CLAY, D., L. CURRIE, and B. SWAN. MS 1984. Food and feeding of silver hake (Merluccius bilinearis Mitchill) on the Scotian shelf with special reference to cannibalism. NAFO SCR Doc. No. 86, Serial No. N876, 25 p.

CLAY, D., and G. NIELSEN. MS 1985. Age specific M and its effect on VPA: Div.4VWX silver hake. NAFO SCR Doc., No.77, Serial No. N1035, 13 p.

COLBOURNE, E. MS 1997. Oceanographic conditions in the Newfoundland region during 1996 with comparisons to the 1961-1990 average. DFO Can. Stock Ass. Sec. Res. Doc., No. 04, 52 p.

CUSHING, D. H. 1971. The dependence of recruitment on parent stock in different groups of fishes. ICES J. Cons., 33(3): 340-362.

DFO. MS 2000. Silver hake on the Scotian Shelf (Div. 4VWX). DFO Science Stock Status Report A3-3.5.

DOMINGUEZ, R., and J. A. VAREA. MS 1986. Results of silver hake otoliths exchange between Cuba, Canada and USSR. NAFO SCR Doc., No.70, Serial No.N1188, 4 p.

DOUBLEDAY, W. G. (editor). 1981. Manual on Groundfish surveys in the Northwest Atlantic. NAFO Sci. Coun. Studies, 2: $55 \mathrm{p}$.

DOUBLEDAY, W. G., and R. G. HALLIDAY. 1976. An analysis of the silver hake fishery on the Scotian shelf. ICNAF Sel. Papers, 1: 41-58.

DRINKWATER, K. F., E. C. COLBOURNE, and D. GILBERT. MS 1997a. Overview of Environmental condition in the Northwest Atlantic in 1996. NAFO SCR Doc., No. 63, Serial No. N2897, 44 p.

DRINKWATER, K. F., R. PETTIPAS, and L. PETRIE. MS 1997b. Marine Environmental Conditions in the Northwest Atlantic during 1996 Potentially Impacting Atlantic Salmon (Salmo Salar). DFO Can. Stock Ass. Sec. Res. Doc., No. 52, 30 p.

EFIMOV, N. I., A. N. SAVATEEVA, and V. L.TRETYAK. MS 1986. On a feasible formal description of the natural mortality rate variation in relation to age of beaked redfish and capelin from the Northwest Atlantic. NAFO SCR Doc., No.64, Serial No. N181, 12 p.

FANNING, L. P., R. K. MOHN, and W. G. MAC EACHERN. MS 1996. Assessment of $4 \mathrm{VsW}$ cod in 1995 with consideration of ecological indications of stock status. DFO Atl. Fish. Res. Doc., No. 27, 34 p.

FUONG, N. MS 1989. On rates of linear and weight growth of Scotian silver hake (Merluccius bilinearis Mitch.). NAFO SCR Doc., No. 17, Serial No. N1593, 13 p.

MS 1990. More on the question of inconsistencies in studying the Scotian Shelf silver hake growth rate by the Soviet and Canadian scientists. NAFO SCR Doc., No.4, Serial No.N1707, 13 p.

GROSSLEIN, M. D. 1969. Groundfish survey methods. U.S. Bur. Comm., Fish. Biol. Lab., Woods Hole, Mass., Lab. Ref., 69/2.

GULLAND, J. A. 1973. Can a study of stock and recruitment aid management decisions. ICES Rapp. Proc.-Verb., 164: $368-372$.

HALLIDAY, R. G. MS 1973. The silver hake fishery on the Scotian Shelf. ICNAF Res. Doc., No. 103, Serial No. $3065,21 \mathrm{p}$.

HUNT, J. J. 1978. Age, growth and distribution of silver hake, Merluccius bilinearis, on the Scotian Shelf. ICNAF Sel. Pap., 3: 33-44.

HUNT, J. J. 1980. Guidelines for age determination of silver hake, Merluccius bilinearis, using otoliths. J. Northw. Atl. Fish. Sci., 1: 65-80.

MS 1985. Comparison of USSR and Canadian estimates of silver hake ageing. NAFO SCR Doc., No.66, Serial No. N1018, 3 p.

MS 1986. Results of Canada-USSR silver hake otoliths exchange. NAFO SCR Doc., No.18, Serial No. N1131, 3 p.

MS 1987a. Results of the 1986 and 1987 CanadaUSSR silver hake otoliths exchange. NAFO SCR Doc., No.52, Serial No. N1341, 5 p.

MS 1987b. An analysis of inconsistencies in estimates of silver hake catch-at-age. NAFO SCR Doc., No. 51, Serial No. 1340, 13 p.

MS 1989. Results of a silver hake otoliths exchange between Canada and the USSR. NAFO SCR Doc., No.11, Serial No. N1579, 5 p.

MS 1991. Comparison of Canadian and USSR estimates of age for 1989 observer program otoliths collections. NAFO SCR Doc., No.7, Serial No.N1879, $7 \mathrm{p}$.

MS 1995. Evaluation of changes in weight at age and growth rate for 4VWX silver hake, 1983-1994. 
NAFO SCR Doc., No.44, Serial No.N2554, 12 p.

ICNAF. MS 1976. Report of silver hake ageing workshop, Dartmouth, Canada, 1-3 April 1976. ICNAF Summ. Doc., No.21, Serial No. 3850, 6 p.

MS 1977. Report of the silver hake ageing workshop, St. Andrews, Canada, 14-18 March 1977. ICNAF Summ. Doc., No.13, Serial No. 5073, 15 p.

MS 1978. Report of silver hake ageing workshop, Dartmouth, Nova Scotia, Canada, 28-31 March 1978. ICNAF Summ. Doc., No.10, Serial No. 5211, 10 p.

KARASIEV, B. E. 1975. Method of short-term prediction of silver hake distribution and behaviour. Kaliningrad, Zaprybpromrazvedka. $45 \mathrm{p}$.

KOELLER, P. A. MS 1981. Vertical distribution and optimum sampling strategy for 0-group silver hake (Merluccius bilinearis) surveys on the Scotian Shelf. NAFO SCR Doc., No.21, Serial No. N288, 13 p.

KOELLER, P. A., J. D. NEILSON, and D. E. WALDRON. MS 1984. The Canada-USSR juvenile silver hake (Merluccius bilinearis) survey on the Scotian Shelf: Abundance indices, distribution and comparison with independent estimates of juvenile abundance, 19781983. NAFO SCR Doc., No.87, Serial No. N877, 9 p.

KOELlER, P. A., P. C. F. HURLEY, P. PERLEY, and J. D. NEILSON. 1986a. Juvenile fish survey on the Scotian Shelf: Implications for year-class size assessments. ICES J. Cons., 43: 59-76.

KOELLER, P. A., P. PERLEY, and J. D. NEILSON. MS 1986b. Canadian juvenile silver hake abundance estimates from joint Canada-USSR surveys on the Scotian Shelf. NAFO SCR Doc., No.54, Serial No. N1171, 11 p.

KOELlER, P. A., L. COATES-MARKLE, and J. D. NEILSON. 1989. Feeding ecology of juvenile (age-0) silver hake (Merluccius bilinearis) on the Scotian Shelf. Can. J. Fish. Aquat. Sci., 46(10): 1762-1768.

MCLELLAN, H. J., L. LAUZIER, and W. B. BAILEY. 1953. The slope water off the Scotian Shelf. J. Fish. Res. Board Can., 10(4): 155-176.

MCLELLAN, H. J. 1954. Temperature-salinity relations and mixing on the Scotian Shelf. J. Fish. Res. Board Can., 11(4): 419-430.

1954. Bottom temperature on the Scotian Shelf. $J$. Fish. Res. Board Can., 13(4): 404-418.

1957. On the districtness and origin of the slope water off the Scotian Shelf and its easterly flow South of the Grand Banks. J. Fish. Res. Board Can., 14(2): 213239.

MARI, A. MS 1980. Distribution, age and growth of silver hake (Merluccius bilinearis) on the Scotian Shelf. NAFO SCR Doc., No. 117, Serial No. N186, 11 p.

MARI, A., and I. RAMOS. 1980. Fecundity of silver hake on the Scotian Shelf. ICNAF Sel. Pap., 6: 2325.

MARI, A., and E. VALDES. MS 1981. Age and growth of silver hake (Merluccius bilinearis) on the Scotian Shelf. NAFO SCR Doc., No. 85, Serial No.N378, 7 p.

MARKOV, Yu., and A. I. SHERSTYUKOV. MS 1991. Microstructure of otoliths, age readings and growth determination of silver hake (Merluccius bilinearis) on early development stages on the Scotian Shelf. NAFO SCR Doc., No.18, Serial No. N1892, 11 p.

MAUCHLINE, J., and L. R. FISHER. 1969. The biology of euphausiidae. Advances in marine biology, Russel and Jonge (Eds.), Vol. 7, $454 \mathrm{p}$.

NEILSON, J. P., and P. PERLEY. MS 1995. The 1994 assessment of pollock (Pollachius virens) in NAFO Division 4VWX and Subdivision 5Zc. DFO Atl. Fish. Res. Doc., No. 30, 47 p.

NOSKOV, A. S. MS 1976. Estimation of stock size and allowable catch of silver hake on the Nova Scotia shelf in ICNAF Division 4W. ICNAF Res.Doc., No.57, Serial No. 3843, 13 p.

NOSKOV, A. S. MS 1985. Assessment of the Scotian silver hake (Merluccius bilinearis) stocks and allowable catch in 1986. NAFO SCR Doc., No. 36, Serial No. N986, $13 \mathrm{p}$.

NOSKOV, A. S., V. P. KARAULOVSKY, A. N. ROMANCHENKO, and A. I. SHERSTYUKOV. MS 1978. Distribution and abundance of silver hake eggs and larvae and environmental conditions off Nova Scotia in September-October 1977. ICNAF Res. Doc., No.32, Serial No.5193, 11 p.

NOSKOV, A. S., A. I. SHERSTYUKOV, and A. N. ROMANCHENKO. MS 1979. Distribution and abundance of silver hake eggs, larvae and juvenile and environmental conditions off the Nova Scotia Shelf in August-October 1978. ICNAF Res. Doc., No. 101, Serial No. 5462, 21 p.

NOSKOV, A. S., V. I. VINOGRADOV, and A. I. SHERSTYUKOV. MS 1982. Results of ecological surveys conducted on the Nova Scotia shelf in 1974 and 1977-1980 to study the spawning efficiency of silver hake. NAFO SCR Doc., No. 33, Serial No. N521, 28 p.

NOSKOV, A. S., and A. I. SHERSTYUKOV. MS 1984. Results of comparative experiments using $13.6 \mathrm{~m}$ and IGYPT trawls. NAFO SCR Doc., No. 65, Serial No. N854, 8 p.

NOSKOV, A. S., A. I. SHERSTYUKOV, and V. I. VINOGRADOV. MS 1985. Distribution and fluctuations of the Scotian silver hake abundance in early stages. NAFO SCR Doc., No. 114, Serial No. N1071, 16 p.

NOSKOV, A. S., and A. I. SHERSTYUKOV. 1985. Distribution and abundance of the young silver hake (Merluccius bilinearis) from data of trawling surveys conducted on the Scotian Shelf in October-November 1978-1983. Sb. trudov AtlantNIRO. Ecology and stocks of some fishing species of the Atlantic Ocean. p. 34-43. (In Russian).

O'BOYLE, R. N., M. SINCLAIR, R. J. CONOVER, K. H. MANN, and A. C. KOHLOR. 1984. Temporal and spatial distribution of ichthyoplankton communities of the Scotian shelf in relation to biological hydrological and physiographic features. The biological productivity of North Atlantic shelf areas (a Symposium held in Kiel, 2-5 March 1982). ICES Rapp. Proc.-Verb., 183: 27-40.

RICKER, W. E. 1954. Stock and recruitment. J. Fish. Res. 
Board Can., 11: 559-623.

1975. Computation and interpretation of biological statistics of fish populations. Bull. Fish. Res. Board Can., No. 191, 382 p.

RIKHTER, V. A. 1972. Estimates of total and natural mortality rates for red hake (Urophycis chuss Walbaum) from the Northwest Atlantic. ICNAF Redbook, 1972(III): 55-58.

MS 1988. More on estimating the instantaneous natural mortality rate for the Div. 4VWX silver hake. NAFO SCR Doc., No. 30, Serial No. N1466, 7 p.

1988. On the problem of "stock-recruitment" relation of silver hake (Merluccius bilinearis Mitchill) in the North-Western Atlantic. Trudy AtlantNIRO. Ecological fishery researchers in the Atlantic Ocean and South-Eastern Pacific, p. 123-139.

MS 1989. Preliminary assessment of the Scotian Shelf silver hake stock size (Div. 4VWX) for 1988 and prospects for 1990. NAFO SCR Doc., No. 14, Serial No. N1590, $11 \mathrm{p}$.

MS 1990. The stock-recruitment dependence nature in some fish species from the Northwest Atlantic. NAFO SCR Doc., No.15, Serial No. N1730, 34 p.

MS 1991. On age changes in natural mortality rates of silver hake on the Scotian Shelf. NAFO SCR Doc., No. 14, Serial No. N1886, 5 p.

MS 1994. On variability of silver hake commercial catches and stocks within the shelf before and after introduction of the 200-mile zone. NAFO SCR Doc., No. 8, Serial No. N2364, 5 p.

MS 1996. Once more and evidently in the last time, an assessment of silver hake natural mortality rate in Scotian area. NAFO SCR Doc., No. 2, Serial No. N2665, $3 \mathrm{p}$.

MS 1997. On probable relation between Scotian cod, haddock, pollock recruitment and silver hake abundance in the area. NAFO SCR Doc., No.3, Serial No. N2828, $6 \mathrm{p}$.

RIKHTER, V. A., and V. N. EFANOV. 1977. On one of the approaches to natural mortality assessment in fish populations. Trudy AtlantNIRO, 73: 77-85.

RIKHTER, V. A., and V. F. TUROK, MS 1984. Distribution of some groundfish species on the Scotian Shelf slopes during the 1983 fishing season from data obtained by USSR observers. NAFO SCR Doc., No. 35, Serial No. N820, 14 p.

RIKHTER, V. A., and E. I. KONOVALOV. MS 1985. On the question of relationship of growth rate of gonads, abundance and timing of silver hake migration from the Scotian shelf slopes in summer. NAFO SCR Doc., No. 34, Serial No. N984, 8 p.

SAMEOTO, D., and N. COCHRANE. MS 1996. Euphausiids on the Eastern Continental Shelf. DFO Atl. Fish. Res. Doc., No. 119, 12 p.

SARNITS, A. A., and V. I. SAUSKAN. MS 1966. Hydrographic conditions and distribution of silver hake (Merluccius bilinearis Mitchill) on Georges Bank and Nova Scotia in 1964. ICNAF Res. Doc., No.51, Serial No. 1660,8 p.

SAUSKAN, V. I. MS 1964. Results of Soviet observations on the distribution of silver hake in the areas of Georges Bank (5z) and Nova Scotia (4W) in 1962-1963. ICNAF Res. Doc., No.61, Serial No. 1357, 8 p.

SAUSKAN, V. I., and V. P. SEREBRYAKOV. 1968. Silver hake reproduction and development. Ichthyological problems, Vol. 8, Iss. 3(50), p.500-521.

SENINA, A. P., and L. I. STULOVA. MS 1986. Comparison of the results of silver hake ageing from the USSR and Canada data. NAFO SCR Doc., No. 99, Serial No. N1176, $6 \mathrm{p}$.

SHCHERBICH, L. V., A. P. SENINA, and Yu. MARKOV. MS 1992. Age determination methods for Nova Scotia hake. NAFO SCR Doc., No. 37, Serial No. N2085, 14 p

.SHEPHERD, J. G. 1982. A versatile new stock-recruitment relationship for fisheries and the construction of sustainable yield curves. ICES J. Cons., 40(1): 67-75.

SHERSTYUKOV, A. I. MS 1990a. Distribution and abundance of 0-group silver hake on the Scotian Shelf in autumn 1988. NAFO SCR Doc., No. 1, Serial No. N1701, $16 \mathrm{p}$.

MS 1990b. The young silver hake growth in the Scotian area, 1977-1988. NAFO SCR Doc., No.2, Serial No. N1702, 11 p.

MS 1991a. Distribution and Abundance of young silver hake of 1989 year-class on the Scotian Shelf in 1989-1990 fall-winter season. NAFO SCR Doc., No.1, Serial No. N1869, 21 p.

MS 1991b.On reproduction and formation of silver hake (Merluccius bilinearis Mitchill) year-class strengths at early ontogenesis on the Scotian Shelf. NAFO SCR Doc., No.19, Serial No. N1893, 18 p.

SHERSTYUKOV, A. I., and G. I. NAZAROVA. 1987. Vertical migration and feeding of the Scotian 0-group silver hake in November 1985. NAFO Sci. Coun. Studies, 15: 53-55.

SHERSTYUKOV, A. I., and V. I. VINOGRADOV. MS 1991. Studies on vertical distribution of Scotian young silver hake in Fall-Winter season 1989-1990. NAFO SCR Doc., No. 2, Serial No. N1870, 14 p.

SHOWELL, M. A. MS 1996. Assessment of the 4VWX silver hake population in 1995. NAFO SCR Doc., No.78. Serial No. N2753, 24 p.

MS 1997. Assessment of the $4 \mathrm{VWX}$ silver hake population in 1996. NAFO SCR Doc., No. 69, Serial No. N2903, $27 \mathrm{p}$.

SHOWELL, M. A., and M. C. BOURBONNAIS. MS 1995. Assessment of the 4VWX silver hake population in 1994. NAFO SCR Doc., No. 76, Serial No. N2593, 22 p.

SIGAEV, I. K. 1969. Annual variations in water temperature in the shelf area of Georges Bank and Nova Scotia in 1962-1968. ICNAF Redbook, 1969 (III): 45-56.

1978. Intra-Year Variability of Geostrophic Circulation on the Continental Shelf off New England and Nova Scotia. ICNAF Sel. Pap., 3: 97-107.

MS 1979. Inter-year seasonal variation in heat content of Northwest Atlantic shelf waters and their correlation with temperature indices by region. ICNAF Res. Doc., No. 56, Serial No. 5396, 16 p.

MS 1985. Year to year variability of water temperatures on the Scotian shelf in summer 1978-1981 
and fall 1977-1984. NAFO SCR Doc., No. 60, Serial No. N1010, 11 p.

1986. Synoptical variability of hydrological fronts location on the surface of Gulf Stream energy-active zone during winter 1984. Fishery-oceanological researches in the Atlantic and South-East Pacific Ocean. Trudy AtlantNIRO, p.4-13 (In Russian).

MS 1988. Distribution of autumn water temperature anomalies on the Scotian Shelf in 1986 and their relative changes in recent decade, 1977-1986. NAFO SCR Doc., No. N1440, 8 p.

MS 1990. Ecological studies of conditions of silver hake distribution on Nova Scotia shelf within the framework of the USSR-Canada program. NAFO SCR Doc., No. 14, Serial No. N1729, 31 p.

MS 1991. Review of Hydrographic conditions in some areas of the Northwest Atlantic, 1990. NAFO SCR Doc., No. 4, Serial No. N187, 12 p.

1992. On possible causes of Scotian silver hake abundance fluctuations. J. Northw. Atl. Fish. Sci., 14: 103-105.

MS 1993. Oceanographic conditions in some areas of the Northwest Atlantic in 1992. NAFO SCR Doc., No. 1, Serial No. N2176, 5 p.

1995. Distribution of silver hake, water temperature and zooplankton on the Scotian Shelf in May-July 1990. NAFO Sci. Coun. Studies, 23: 1-7.

1996a. On water masses boundaries interannual and seasonal variability in North-Western Atlantic Ocean and its impact upon some commercial species fishery.-Fishery and biological researches carried out by AtlantNIRO in 1994-1995. Trudy AtlantNIRO, p. 64-73.

1996b. Ecological conditions of silver hake concentration in the Scotian shelf area. NAFO Sci. Coun. Studies, 24: 109-124.

2000. Internannual variability of sea surface temperature and dynamics of surface water boundaries in the systems of the Labrador Current and the Gulf Stream. Fisheries and biological research by AtlantNIRO in 1998-1999. Trudy AtlantNIRO, p. 37-56.

SIGAEV, I. K., A. I. SHERSTYUKOV, and N. K. ISTOMINA. MS 1988. Distribution and abundance of 0-group silver hake and thermal conditions of Scotian Shelf waters in October-November 1987. NAFO SCR Doc., No. 98, Serial No. N1555,18 p.

SIGAEV, I. K., and V. A. RIKHTER. 1996. Relationship of some commercial fish species year-class abundance and hydrological conditions in the Northwest Atlantic. NAFO Sci. Coun. Studies, 24: 87-90.
SIGAEV, I. K., V. A. RIKHTER, AND P. S. GASIUKOV. MS 2000. Russian research report for 1999. Part 1. Research carried out by AtlantNIRO. NAFO SCS Doc., No. 9, Serial No. N4221, 22 p.

TERRÉ, J. J., and A. MARI. 1978. Estimates of natural mortality for the silver hake stock on the Scotian shelf. ICNAF Sel. Pap., 3: 29-31.

TIURIN, P. F. 1962. Factor of fish natural mortality and its importance in fishery regulation. Ichthyological problems, Vol.2, Iss. 3(24), p. 403-427 (In Russian).

TIZOL, R., and C. GARCIA. MS 1988. Age and growth of silver hake (Merluccius bilinearis) on the Scotian Shelf. NAFO SCR Doc., No. 2, Serial No. N1434, 2 p.

TRETIAK, V. L. 1984. Method of fish natural mortality estimation in various ages (illustrated with ArcticNorwegian cod). PINRO. Ecology of biological resources of the Northern Basin and their fishery and utilization, p. 85-102. (In Russian).

VINOGRADOV, V. I. 1984. Food of silver hake and other fishes of Georges Bank and adjacent waters, 1968-1974. NAFO Sci. Coun. Studies, 7: 87-94.

1986. Distribution of fish food in the trophic chain in the ecosystem of Georges Bank and possibility of multispecies fishery regulation. In: Biological resources of the Atlantic Ocean, M. Nauka (ed.), p. 259-265.

1988. Feeding and some conditions of silver hake fishery in Scotian Shelf area in 1977-1985. Thesis of the report at All-Union Conference "Feeding of marine fishes and utilization of forage base as the element of fishery prediction", Murmansk, p. 85-86.

MS 1993. On hake feeding related to distribution of food organisms in the Scotian Shelf area in 1988, 1990. NAFO SCR Doc., No.7, Serial No. N2182, 13 p.

MS 2000. Feeding of 0-group silver hake (Merluccius bilinearis) in Scotian Shelf area. NAFO SCR Doc., No. 3, Serial No. N4214, 14 p.

WALDRON, D. E. MS 1989. Cannibalism in the Scotian Shelf silver hake population and how it may influence population status. NAFO SCR Doc., No.81, Serial No. N1665, 37 p.

1992. Diet of silver hake (Merluccius bilinearis) on the Scotian Shelf. J. Northw. Atl. Fish. Sci., 14: 87-101.

WALDRON, D. E., L. P. FANNING, M. C. BOURBONNAIS, and M. A. SHOWELL. MS 1988. Size of the Scotian Shelf silver hake population in 1987. NAFO SCR Doc., No.51, Serial No. N1491, 33 p.

ZWANENBURG, K., G. A. P. BLACK, and G. YOUNG. MS 1995. Haddock in Division 4TVW in 1994. DFO Atl. Fish. Res. Doc., No. 112, 69 p. 